NBER WORKING PAPER SERIES

\title{
A SURVEY OF VENTURE CAPITAL RESEARCH
}

\author{
Marco Da Rin \\ Thomas F. Hellmann \\ Manju Puri \\ Working Paper 17523 \\ http://www.nber.org/papers/w17523
}

\author{
NATIONAL BUREAU OF ECONOMIC RESEARCH \\ 1050 Massachusetts Avenue \\ Cambridge, MA 02138 \\ October 2011
}

We would like to thank Klazina van den Berg and Yaping Mao for their valuable research assistance. All errors are ours. The views expressed herein are those of the authors and do not necessarily reflect the views of the National Bureau of Economic Research. Forthcoming in George Constantinides, Milton Harris, and René Stulz (eds.) Handbook of the Economics of Finance, vol 2, Amsterdam, North Holland, 2012.

NBER working papers are circulated for discussion and comment purposes. They have not been peerreviewed or been subject to the review by the NBER Board of Directors that accompanies official NBER publications.

(C) 2011 by Marco Da Rin, Thomas F. Hellmann, and Manju Puri. All rights reserved. Short sections of text, not to exceed two paragraphs, may be quoted without explicit permission provided that full credit, including $(\subset$ notice, is given to the source. 
A survey of venture capital research

Marco Da Rin, Thomas F. Hellmann, and Manju Puri

NBER Working Paper No. 17523

October 2011

JEL No. G21,G23,G24

\section{ABSTRACT}

This survey reviews the growing body of academic work on venture capital. It lays out the major data sources used. It examines the work on venture capital investments in companies, looking at issues of selection, contracting, post-investment services and exits. The survey considers recent work on organizational structures of venture capital firms, and the relationship between general and limited partners. It discusses the work on the returns to venture capital investments. It also examines public policies, and the role of venture capital in the economy at large.

Marco Da Rin

Department of Finance-Office K 936

Tilburg University

Warandelaan 2

P.O. Box 90153

5000 LE Tilburg

The Netherlands

and European Corporate * RYHQDOFH

$\square$ Network (ECGI) and IGIER

marco.darin@uvt.nl

Thomas F. Hellmann

Sauder School of Business

University of British Columbia

2053 Main Mall

Vancouver, BC V6T 1Z2

CANADA

and NBER

hellmann@sauder.ubc.ca
Manju Puri

Fuqua School of Business

Duke University

1 Towerview Drive, Box 90120

Durham, NC 27708-0120

and NBER

mpuri@duke.edu 


\section{Table of Contents}

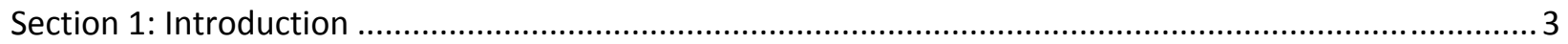

Section 2: Data sources and methodology for empirical research ..................................................... 6

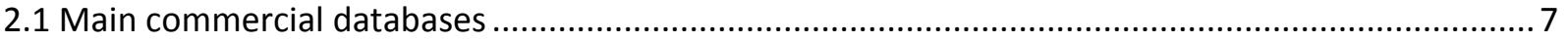

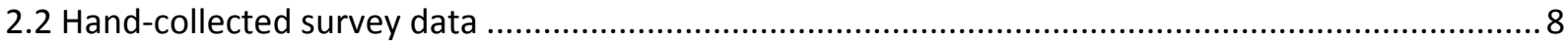

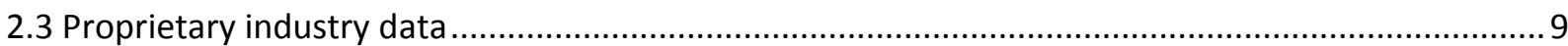

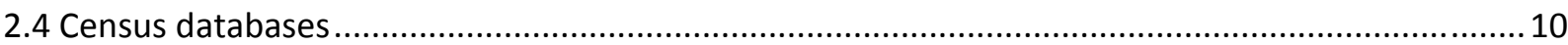

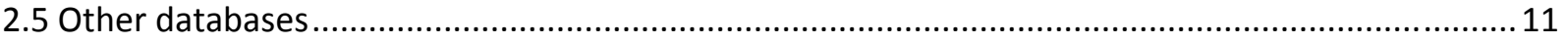

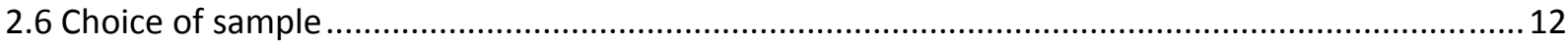

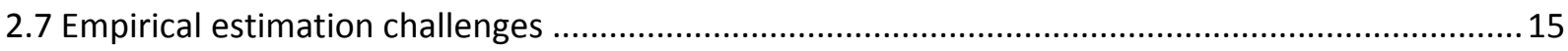

Section 3: Venture capital investments in entrepreneurial companies ................................................ 16

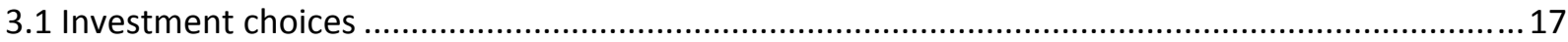

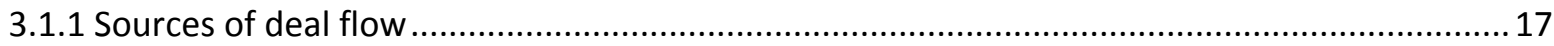

3.1.2 The choice between venture capital and alternative funding sources..................................20

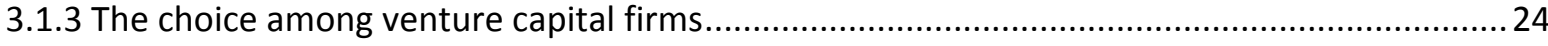

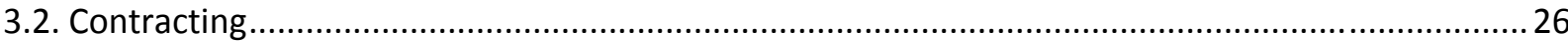

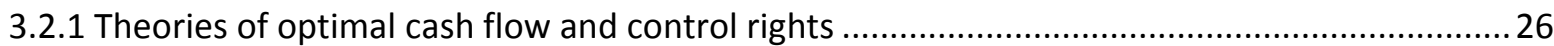

3.2.2. Empirical evidence on venture capital contracts............................................................ 31

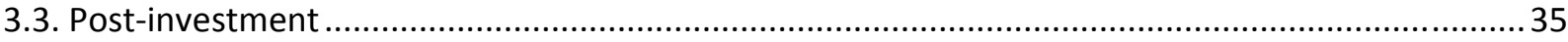

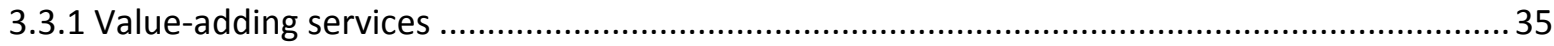

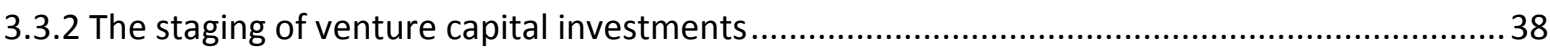

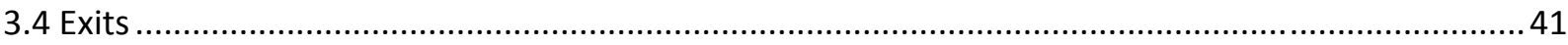

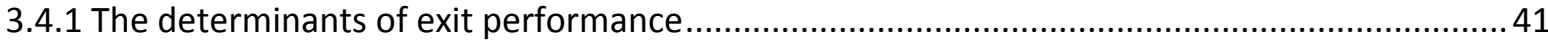

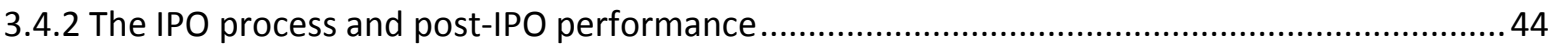

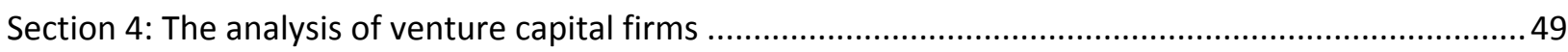

4.1. The organizational structure of venture capital firms .................................................................... 49

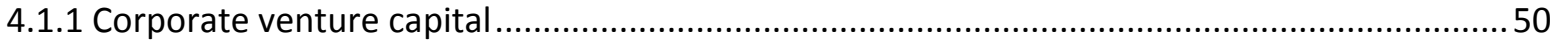

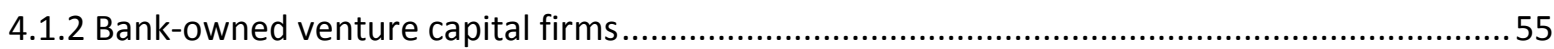

4.1.3 Government-sponsored venture capital firms …................................................................. 56

4.1.4 The internal organization of venture capital firms …............................................................ 59

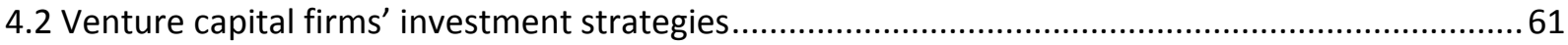




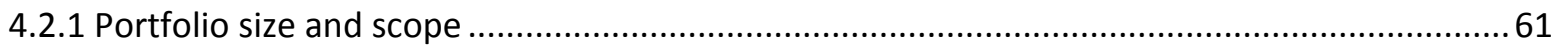

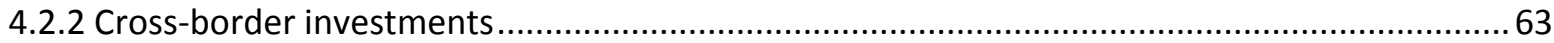

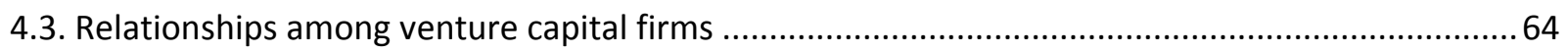

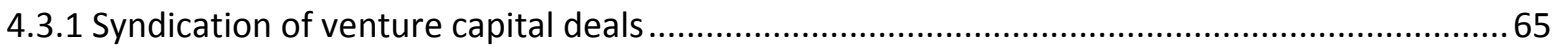

4.3.2 Social networks among venture capital firms ....................................................................... 67

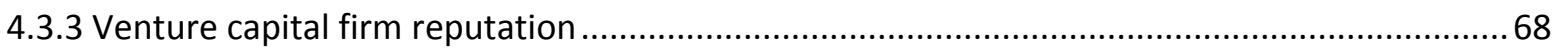

4.4. The relationship between General and Limited Partners.......................................................... 70

Section 5: Returns to venture capital investments............................................................................. 72

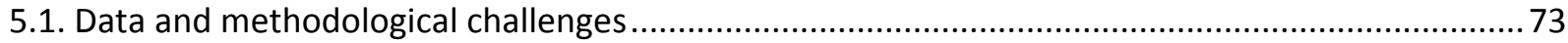

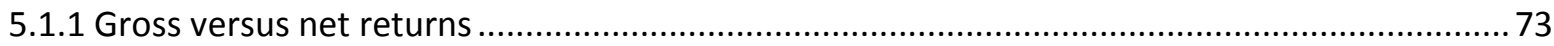

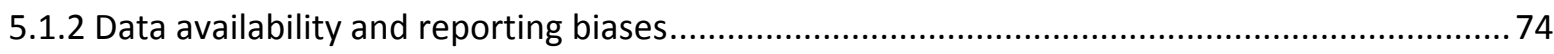

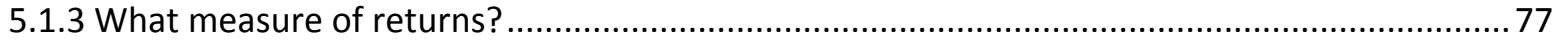

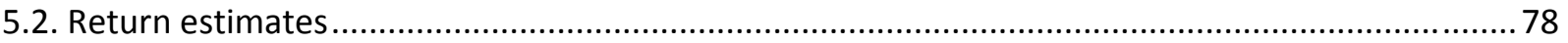

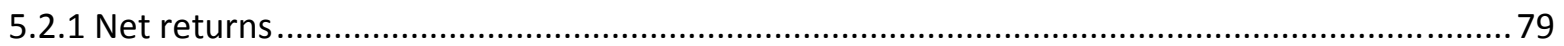

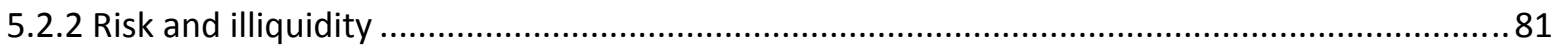

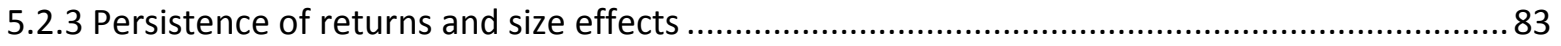

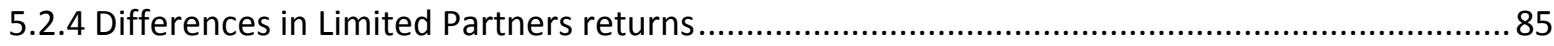

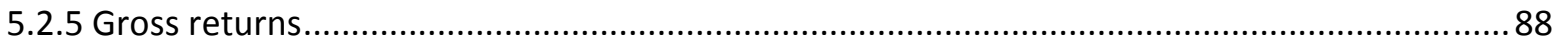

5.2.6 Comparison to other private equity investment returns .....................................................90

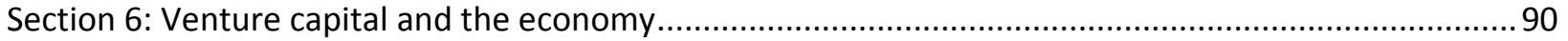

6.1 The contribution of venture-backed companies to innovation ...................................................91

6.2 The role of venture capital for entry, employment and growth................................................... 94

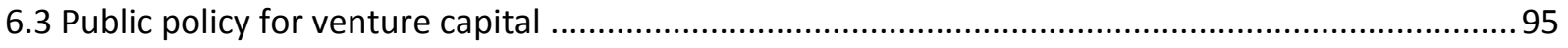

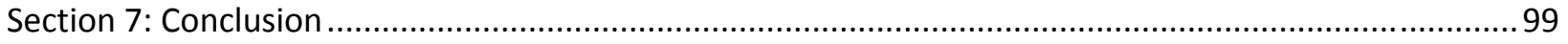

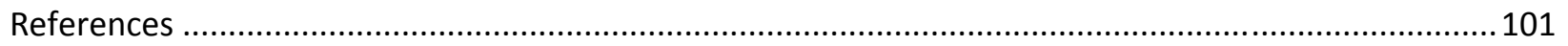




\section{Section 1: Introduction}

This survey reviews the growing body of academic research on venture capital (VC henceforth). By $\mathrm{VC}$ we mean the professional asset management activity that invests funds raised from institutional investors, or wealthy individuals, into promising new ventures with a high growth potential. We therefore exclude other forms of investments in these companies by non professional investors like business angels, and other forms of financial intermediation that are targeted at different types of private companies, like buyouts, turnarounds, or mezzanine finance. We also leave out most of literature on entrepreneurship that is not closely related to VC. Our survey focuses mostly on scholarly work done in the fields of economics and finance, though we do include some contributions from legal and management scholars that we feel provide a useful complement to the economics and finance approach. Our hope is to provide a comprehensive review of this academic literature, highlighting the main findings and pointing to some of the open issues.

The VC industry has grown dramatically over the past thirty years. In 1980 the amount of VC investments in the US was $\$ 610$ million, according to PricewaterhouseCoopers Moneytree. By 1990 this figure had increased to $\$ 2.3$ billion. After peaking at over 100 billion during the socalled "dot.com bubble," by 2010 the amount invested was around $\$ 30$ billion. According to Preqin, over 200 new VC funds have been created each year on average since 2000, raising over 50 billion from institutional investors. While the US still dominates, Europe and Asia now attract about half of the total investment flows. ${ }^{1}$

It is useful to briefly explain the typical structure of VC markets, as shown in Figure 1 below. Venture investors are organized in small partnerships of up to a dozen individual

\footnotetext{
${ }^{1}$ See Kaplan and Lerner (2010) for the US and Aizenman and Kendall (2008) for a global perspective.
} 
partners; these are the VC firms. In order to make investment in start-ups, $\mathrm{VC}$ firms raise money from institutional investors and wealthy individuals through vehicles called 'funds.' The contract that underlies a fund is traditionally a partnership, where the VC firm exerts active management, and therefore assumes unlimited liability, whereas the investors retain unlimited liability by not interfering with the fund's operations. From this structure originate the common terms of Limited Partners (LPs), for institutional investors and wealthy individuals, and of General Partner (GPs), for the VC firm. During the ten years of the fund's typical lifetime, GPs make the selection of portfolio companies, can monitor, mentor and provide value added services, and ultimately exit from the companies, distributing the returns to their LPs. GPs receive their compensation in the form of a management fee and of performance-based payments called "carried interests" (or just "carry"). Notice that we follow the literature's tendency to identify the term 'firm' with the GP, and the term 'company' with the start-ups that are finance.

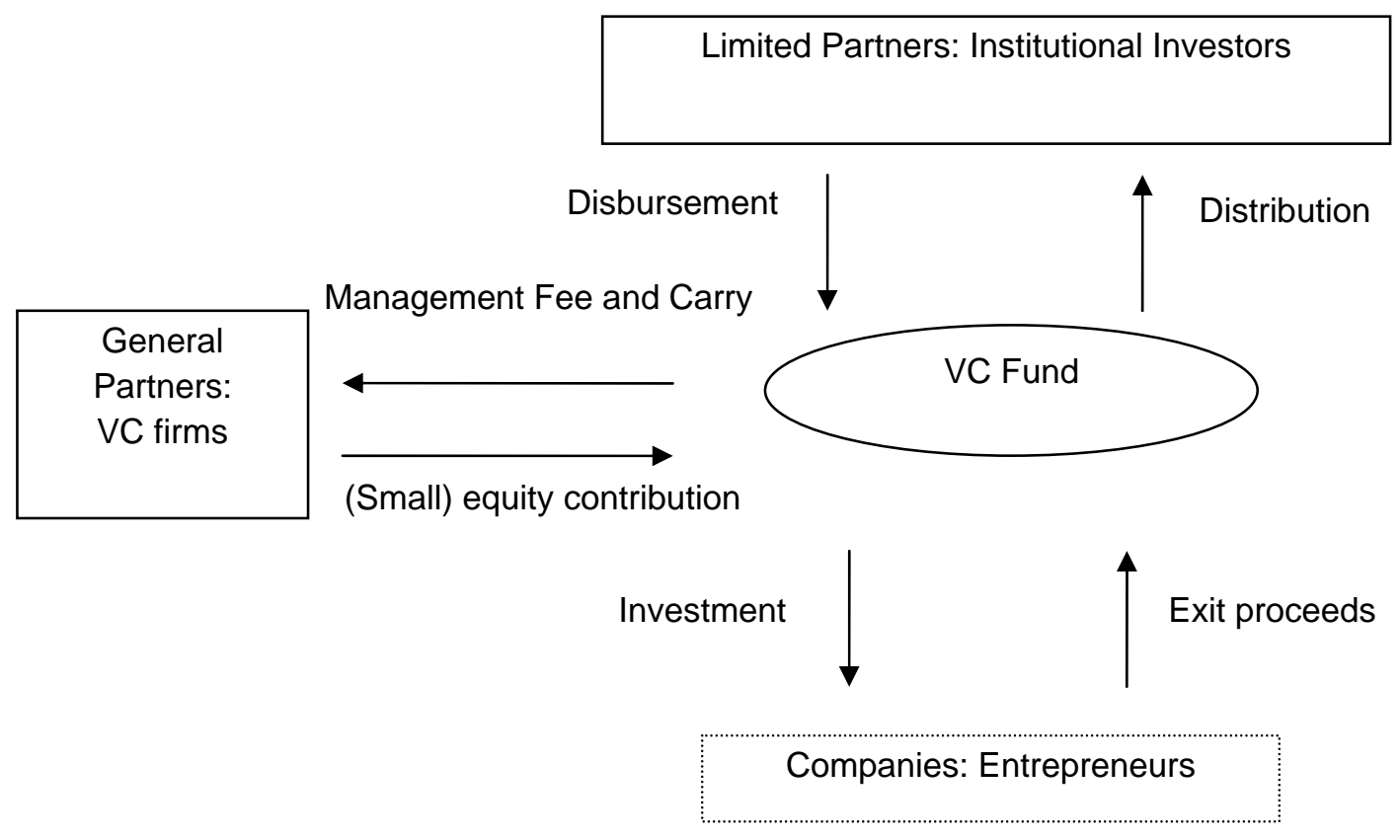




\section{Figure 1}

Figure 1 helps us identify the three main research strands in the VC literature. One important set of questions deals with the interaction between entrepreneurial companies and VC, relating to deal flow, selection, investment, effort provided by the entrepreneur and by the VC as well as the exit strategy. Another set of questions pertains to the interaction between the VC fund and its investors, relating to fundraising, compensation structure, and distributions of the returns to VC. The figure clearly simplifies many aspects, for example there are alternative organizational forms of VC, where LPs are corporations or banks, rather than institutional investors. A third set of questions is about the organization of VC firms and the relations among them.

$\mathrm{VC}$ research has made much progress in the last decade, with a growing number of papers being written. This has occurred for a variety of reasons. There has been the natural growth in the field following the growing importance of $\mathrm{VC}$ over the last two decades. There has also been recognition that in addition to being an interesting field in its own rights, $\mathrm{VC}$ research can also contribute to understanding broader economic issues, such as incentives and contracting theories. Yet another factor that has helped VC research is the growing availability of data, both in the form of commercial databases, and thanks to initiatives taken by researchers to build datasets based on private data. More sophisticated empirical techniques are also being incorporated into research. These include methods to separate out selection and treatment effects; efforts to use statistical techniques to deal with limitations of the data or to make statements about the role of VC in different contexts. Yet, much remains to be done. In our view VC research remains an area of high potential for research, and we point to some of the areas ripe for exploration in the conclusion to the survey. 
Several other surveys cover some of the ground covered here, although each survey has a different focus. Sahlman (1990) provides a useful overview of the structure of the VC industry. Gompers and Lerner (2001) review the literature on VC up until then. The field has since developed at a very fast pace. Gompers (2007) focuses on some recent empirical work. Kaplan and Strömberg (2009) look at the literature on buyouts. Metrick and Yasuda (2011) provide a shorter survey of private equity, including both the research on VC and buyouts. Kerr and Nanda (2011) review research on the broader field of entrepreneurial finance, but then focus more narrowly on the role of financing constraints.

The rest of the survey is organized as follows. Section 2 covers the main data sources used in empirical VC research and highlights the main methodological challenges. Section 3 examines VC investments in entrepreneurial companies, in particular looking at the selection and matching of VCs to companies, contracting, post-investment services, and exits. Section 4 analyzes VC firms themselves, the different kinds of organizational structure, their investment strategies, relationships among VC firms, and the relationship between GPs and LPs. Section 5 examines the returns to $\mathrm{VC}$ investments, and the related data and methodological challenges. Section 6 examines the role of $\mathrm{VC}$ in the economy and the role of public policy. Section 7 concludes.

\section{Section 2: Data sources and methodology for empirical research}

In this section we discuss the fundamental building blocks that empirical VC research is based on. One of the main constraints in doing research on $\mathrm{VC}$ has been the limited availability of data. In sections 2.1 to 2.5 we therefore describe the different sources of data that have been used, and the benefits and limitations of these databases. In section 2.6 we discuss sampling issues, and in section 2.7 we discuss some common issues with empirical estimation. 


\subsection{Main commercial databases}

The two primary commercial databases that have been used by many researchers are ThomsonOne and VentureSource. ThomsonOne, formerly known as VentureXpert and as Venture Economics before that, is offered by Thomson Financial, a unit of Thomson Reuters. VentureSource, formerly known as VentureOne, is offered by VentureOne, a division of Dow Jones. ThomsonOne has been available to a larger number of academicians, resulting in it being used more extensively than VentureSource.

An early paper by Lerner (1995) examines the completeness of ThomsonOne and finds that $12 \%$ of VC-backed biotech companies were missing from the database. He also finds that the number of financing rounds is overstated because of staged investments being reported as multiple rounds. Detailed discussions of the quality of these databases with a systematic comparison to underlying data obtained from an independent source are provided by Kaplan et al. (2002), and more recently by Maats et al. (2011). Kaplan et al. (2002) study a sample of 213 VC investments in 119 portfolio companies by 14 partnerships they obtained by asking the VCs to provide as much detailed information as they were willing to provide. They find that both ThomsonOne and VentureSource exclude roughly $15 \%$ of the financing rounds. VentureSource has better coverage of post-money valuations, but is biased towards reporting valuations of highly valued companies. ThomsonOne oversamples companies located in California and larger financing rounds. They conclude that the financing amounts are measured with a fair amount of error in both databases, but the amounts tend to be unbiased on average.

Maats et al. (2011) also provide a detailed comparison of ThomsonOne and VentureSource. They select a sample of 40 funds raised by 36 VC firms between 1993 and 2003 from which they construct samples at the fund level, company level and round level. At the fund 
level they find that coverage increases with the number of portfolio companies. The reliability of fund coverage is higher in ThomsonOne than in VentureSource. At the company level VentureSource is more reliable in reporting exit and ownership status. At the round level, the consistency between VentureSource and ThomsonOne is higher than at the company level.

While ThomsonOne and VentureSource are useful databases for the study of VC they do not contain all the detail that researchers might be interested in, nor do they include any control groups of companies that do not obtain VC. Researchers have adopted a number of approaches to get around this. Since this is done by many papers, we illustrate different approaches with a few papers rather than provide a comprehensive list of all the papers that have used any one approach.

\subsection{Hand-collected survey data}

One approach is to hand-collect data, mostly through surveys, possibly augmenting them with data from interviews and from commercial databases. This approach was used, for example, by Hellmann and Puri $(2000 ; 2002)$ who obtain detailed data on 173 Silicon Valley technology start-ups, by Hsu (2004) who obtained data on 149 MIT start-ups, or by Bottazzi et al. (2008, 2009) who obtain data on 1,652 companies from 119 European VCs. The advantage of this approach is that it allows access to interesting firm-specific data that would not be captured in commercial databases, such as the company's choice of innovation strategy, the investment offers not taken, or the human capital of VCs. One disadvantage is that collecting large samples is costly, so that the resulting sample size is sometimes limited. Therefore, the scope of such studies is somewhat limited.

The most ambitious collection of survey data to date is the Kauffmann firm survey, which tracks nearly 5,000 entrepreneurial companies from their birth to the first few years of 
their life (Robb et al., 2010). Robb and Robinson (2010), for example, use this database to examine the capital structure choices of start-up companies. As only $1 \%$ of companies are venture backed, this database has been used more for entrepreneurship research rather than VC research.

While researchers have no control over sampling procedures with the commercial databases, they retain such control when hand-collecting data. Control over sampling comes with the responsibility of showing the representativeness of the sample. Ideally this includes a comparison of the hand-collected sample to more aggregate statistics (Bottazzi et al., 2008; Robb et al., 2010). It is also important to cross-check hand-collected data with other available databases. Exits need to be cross-checked with the SDC New Issues database (or with stock exchange databases) for IPO issuances, and with the SDC M\&A and Bureau van Dijk's Zephyr databases for acquisitions. CorpTech has also been used to augment data for young companies, e.g., to identify young companies (Baron et al., 1996; Hellmann and Puri, 2000), or to create finer industry classifications than SIC codes (Masulis and Nahata, 2009).

\subsection{Proprietary industry data}

Closely related to hand-collected data is proprietary data from industry participants. Kaplan and Strömberg $(2003 ; 2004)$ and Kaplan et al. (2007) obtain proprietary data from 14 VC firms. They obtain detailed information about the contracts and investment memorandum, which allows them to study how VC deals inform contracting theories. In a related vein, Bengtsson and Sensoy (2011a) obtain data on contracts from a private equity consulting firm called VCExperts (not to be confused with VentureXpert - which is now ThomsonOne). VCExperts collects data from Certificates of Incorporation that US companies are required to file with their state of incorporation when making changes to their outstanding equity (e.g., issuing preferred stock to 
VCs). Data can come also from service providers. Goldfarb et al. (2009) obtain data on financing contracts by accessing the client files of a defunct law firm called Brobeck, Phleger \& Harrison.

A number of researchers obtain data directly from LPs or institutional investors. For example, Gompers and Lerner (1998a) use this approach to obtain a set of over 700 transactions by 135 venture funds based on records of four LPs. Some studies examining returns also use this approach. Ljungqvist and Richardson (2003) and Robinson and Sensoy (2011a; 2011b) both obtain data from a single large LP. Lerner et al. (2007) get data from 20 LPs to examine their returns.

\subsection{Census databases}

Recently, researchers have used the Census databases as an alternate approach to find data that includes a control group of companies that do not get VC. Puri and Zarutskie (2011), and Chemmanur et al. (2011a) both adopt this approach. Puri and Zarutskie (2011) use the LBD (Longitudinal Business Database) that is a panel covering all companies with any employees in the US. They analyze the life cycle dynamics of VC and non-VC-backed companies, focusing on failure, which is not well recorded in other databases, where many bankrupt companies are retained as 'living dead,' i.e., they appear to be active rather than shown to have failed. Chemmanur et al. (2011a) use the LRD (Longitudinal Research Database) to examine manufacturing companies which did or did not receive $\mathrm{VC}$ funding and analyze total factor productivity, which is difficult to measure elsewhere.

Many researchers use successful exit outcomes (IPO or acquisition) as a proxy for a profitable investment. However, exit is poorly measured in most databases, including in the ThomsonOne and VentureSource databases and even the Census. All careful researchers should therefore augment these databases. For IPOs, cross checks are commonly done with SDC's New 
Issues database which lists all IPOs. Acquisitions are trickier to measure so researchers typically use a variety of approaches. Puri and Zarutskie (2011), for example, supplement the Census (LBD) database with SDC M\&A and Lexis/Nexis. They find that adding these searches increases the set of identified acquisitions in the Census database leading to an increase in the total acquisition rate from $20.0 \%$ to $24.9 \%$, for VC-backed companies, and from $4.3 \%$ to $5.7 \%$, to non-VC-financed companies.

\subsection{Other databases}

Given the limitations of the main databases such as ThomsonOne or VentureSource, and given that the extant literature already explored the 'low-hanging fruit,' recent contributions often combine them with other databases. Several papers combine ThomsonOne with the NBER US patent data base to assess the relationship between VC and innovation. Lerner (1994a) obtains data from Recombinant Capital, is a San Francisco based firm that collects information on the biotech industry. Hellmann et al. (2008) use the LPC Dealscan data on bank lending. In recent years CapitalIQ has become a competitor to the ThomsonOne database. Its strength is mostly buyouts, but it also contains some valuable information about VC firms (see Bernstein et al., 2010). Samila and Sorenson (2011) combine a variety of census data about aggregate economic activity at the level of Metropolitan Statistical Areas. Hsu (2006) uses a database that matches companies receiving a federal R\&D subsidy from the US Small Business Innovative Research

Program to other VC-backed companies. Moskovitz and Vissing-Jorgenson (2002) and Puri and Robinson (2011a; 2011b) use the Survey of Consumer Finances (SCF) to address questions about the "private equity premium puzzle." Brander et al. (2010a) augment ThomsonOne with deal-level data from the Asian Venture Capital Journal to obtain better coverage of Asian deals. 
While the databases provide some data on the returns to VC firms, there have been several efforts at completing this data. Sand Hill Econometrics, recently acquired by Dow Jones, augments VentureSource with other proprietary sources to obtain more reliable valuations at the investment round level, and less biased returns at the VC fund level. CEPRES, a joint venture of Frankfurt University and the Deutsche Bank, also provides investment level data, reporting cash flows between VC funds and individual portfolio companies. Preqin is a relatively new data provider, whose database contains fundraising and return data for a large variety of investment funds, including VC funds. In section 5 we provide a more detailed discussion of VC returns data.

There are also a number of aggregate data reported by various $\mathrm{VC}$ associations, such as the NVCA (National Venture Capital Association) and the EVCA (European Private Equity and Venture Capital Association), and by the AVCJ (Asian Venture Capital Journal). While these are useful for understanding trends, they are typically used as a supplement or to motivate research.

\subsection{Choice of sample}

Given the variety of data sources and research questions, different papers use different sample approaches and different units of observations. One fundamental issue is the choice of control sample. Many studies choose to sample companies that are VC-backed. Such samples are suitable for shedding light on differences among VCs and VC-backed companies, for example comparing the effects of receiving funding from independent vs. captive VC firms, or from firms with higher reputation or higher human capital. This approach, however, cannot inform us on how VCs differ from other sources of entrepreneurial finance. Several papers, therefore, identify a credible control sample of non-VC-backed companies, based on census data (Puri and Zarutskie, 2011; Chemmanur et al., 2011a), or based on alternative sampling criteria, such as 
being located in certain high technology clusters (Hellmann and Puri, 2000; Hsu, 2004), or obtaining certain research grants (Hsu, 2006).

Researchers also need to define the exact scope of their analysis. One issue is the geographic scope. Many studies focus on the US, which has the largest VC market and probably has the best data coverage. Even within a US sample, choices have to made about whether or not include foreign VC firm that invest in US companies and US VC firms that invest outside the US. Needless to say, a more global analysis is often more satisfactory. By 2011 non-US investments accounted for approximately half of all $\mathrm{VC}$ investments, and the quality of these data have improved considerably over the last decade. A further sampling dimension is the time period that is covered by the analysis. Longer periods provide more observations but care has to be put in controlling for the cyclicality of the industry and for change in the type of technologies being funded. Another scope aspect is the distinction between $\mathrm{VC}$ and other private equity investments. However, no clean definitions or clear demarcations exist. The difference between $\mathrm{VC}$ and buyouts is fairly apparent - $\mathrm{VC}$ is used for making investments in young growing companies whereas buyout capital is used to acquire established companies. There is, however, a murky middle ground between these two. Growth capital, for example, is a type of private equity financing for companies that are beyond the start-up stage, where funds are used for investment, not for buying out existing owners. Another example is turnaround capital, which is partly used for buying out existing owners, and can be applied to companies at all stages, including relatively young companies.

One also needs to carefully define the boundaries between funding provided by private 'independent' VC funds and by 'captive' VC funds, such as bank or corporate funds, which we examine in section 4. Angel financing by wealthy individuals, some of which are experienced 
industry executives, is becoming important, but is a form of non-institutional finance that is best studied separately. In practice, researchers typically rely on the definitions provided by the industry participants or commercial data providers, although some verification of the definition of $\mathrm{VC}$ is always advisable.

We would argue that in the area of VC, all databases have some sample selection issues. This is because it is conceptually impossible to clearly define a company's birth date. The most common measure is the date of incorporation, but there are several problems with this.

Entrepreneurs typically engage in substantial economic activities prior to incorporation, such as doing research, developing a business plan, or raising funds. As noted by Gompers et al. (2005), many entrepreneurial ideas even originate within larger corporations. In some cases the incorporation is also based on some unobservable prior entity, such as a sole proprietorship. Moreover, if one takes the whole sample of incorporated companies, these include a large number of entities, such as tax shelters, that cannot be considered proper companies. Hence the impossibility of objectively defining a company's birth date, and thus of eliminating all survivorship bias. ${ }^{2}$

Notwithstanding these conceptual problems, researchers typically try to obtain data that sample companies at the earliest feasible date. The Kauffman Survey, for example, uses the data of incorporation. Commercial databases typically capture companies at the time of the first VC round. Some researchers also use a reverse logic of sampling companies at the time of IPO, identify which are VC-backed and not, and then go backwards to collect data on the earlier stages of the company (Bottazzi and Da Rin, 2002; Masulis and Nahata, 2009). One advantage of

\footnotetext{
${ }^{2}$ The Panel Study of Entrepreneurial Dynamics (PESD) is a large research project largely outside of the disciplines of finance and economics that tries to identify the antecedents to the start-up decision, surveying households and asking them about their entrepreneurial ambitions and intentions. Even there many sampling problem arise. See http://www.psed.isr.umich.edu/psed/home.
} 
this approach is that it is relatively easy to obtain data on both $\mathrm{VC}$ - and non-VC companies, but there is also a significant disadvantage in terms of selection bias, analyzing only the successful companies without being able to control for what happened to all the unsuccessful companies. The appropriateness of their sampling choice clearly depends on the questions that are asked.

\subsection{Empirical estimation challenges}

There are a large number of issues that need to be carefully considered in empirical estimation. Here we briefly go through the main issues, and point to the most common approaches for dealing with them. Many papers in the VC literature want to identify some causal effect of VC financing, either as a whole category, or looking at the differential effects of different types of VCs. A central concern here is the distinction between selection and treatment effects. VC transactions involve at least two parties, so that selection effects may pertain to both the VC and the entrepreneur sides of the market. A common challenge is that data is typically only available for those entrepreneurs who obtained VC financing, but the counterfactual, those who did not get $\mathrm{VC}$, is often missing. Moreover, there may be unobserved heterogeneity in underlying attributes of both parties that might affect the matching of entrepreneurs with VCs. Also the choice of actions and contract characteristics is likely to be driven by unobserved company characteristics, and therefore endogenous. These issues become even more complex when timing is taken into account to gauge the effect of (different types of) VC funding on outcomes.

Another common challenge to the analysis is the issue of reverse causality, where expectations about future events may drive agent's actions, like the expectation of a quick IPO may convince the VC to invest rather than investment leading to a quick IPO. Note also that all of these problems are relevant not only for the relationship between entrepreneurs and VCs, but 
similarly for the relationship between VCs and LPs. And similar issues arise when looking at more aggregated data that tries to examine issues such as the effect of $\mathrm{VC}$ on the economy.

A variety of methods are used to deal with these issues. These include instrumental variables, Heckman selection models, switching regressions, propensity scores, difference-indifference estimates, regression discontinuity, and others. Each of these techniques has its own pros and cons, and depending on the issue under study, some techniques may be more suitable than others. For example, to use instrumental variables, a suitable instrument is needed, one that satisfies the exclusion restriction. Heckman selection models and switching regressions deal with selection on unobservables. Propensity scoring works well for matching on observables but cannot deal with selection on unobservables. Difference-in-difference estimates hinge on a 'parallel trends' assumption. Regression discontinuity designs require an observable exogenous rule governing assignments to different groups. A full discussion of these techniques is clearly beyond the scope of this survey. Two excellent survey articles that extensively discuss the relevant methods, their applicability and limitations are Li and Prabhala (2007) and Roberts and Whited (2012, chapter XX in this Handbook)

\section{Section 3: Venture capital investments in entrepreneurial companies}

In this section we examine the relationship between VCs and their portfolio companies. We start by looking at how VCs and entrepreneurs find each other. We then examine the contracts between VCs and companies, VCs' post-investment relationship with companies, and finally how VCs exit companies. 


\subsection{Investment choices}

\subsubsection{Sources of deal flow}

We begin by examining the main sources of deal flow, i.e., where entrepreneurs come from. This touches on a large entrepreneurship literature, but we limit our discussion to those parts that are most relevant for VC financing. One important source of deals is so-called 'spin-offs.' ${ }^{3}$ In a broad study of entrepreneurs, Bhidé (1994) notes that "71 percent of all founders had replicated or modified an idea encountered through previous employment." Gompers et al. (2005) find that $30 \%$ to $42 \%$ of all VC-backed founders came from public companies. Their analysis suggests that companies located in Silicon Valley and Boston's route 128, often having been previously backed by VCs, are the most prolific 'spawners' (i.e., parent of spin-off companies). They also show that diversified companies are less likely to spawn, and that spawning rates are highest in time of declining sales at the parent company. Klepper and Sleeper (2005) provide a detailed analysis of the laser industry and find that more successful companies are more likely to spawn, and that spin-offs benefit from their parents' technical and market-related knowledge. ${ }^{4}$

Legal rules governing employee departures clearly matter for the spin-off process (see Fallick et al., 2006; Franco and Filson, 2006; Franco and Mitchell, 2008). Hyde (1998) and Gilson (1999) argue that Silicon Valley benefitted from California's courts who have a lax approach to trade secret enforcement, and who refuse to enforce non-compete covenants under a wide range of circumstances. Stuart and Sorenson (2003) empirically examine this by looking at the rate at which new biotechnology companies are started within local markets, defined as US

\footnotetext{
${ }^{3}$ The term "spin-off" can refer to two distinct phenomena: (i) employees starting new ventures without maintaining formal ties to their previous employer, and (ii) employees starting new ventures where the employer maintains some commercial interest in the venture, possibly in the form of an equity stake or licensing deal. In this survey we use the term spin-off to the former, and refer to the latter as a "corporate spin-off." Note that some authors prefer the terms "spin-out" to "spin-off."

${ }^{4}$ For theories about the spin-off process, see Cassiman and Ueda (2006), Hellmann (2007), Hellmann and Perotti (2011), Klepper and Thompson (2010), and Sevilir (2010).
} 
Metropolitan Statistical Areas. IPOs and diversifying acquisitions of biotechnology companies increase the local biotech start-up rate, consistent with employees leaving their employer in times of change, to start their own company. The key finding is that this effect only holds in states where the enforcement of "non-competes" is weak. Marx et al. (2009) provide further empirical support from a quasi-natural experiment in Michigan, where there was an unexpected reversal of the legal enforcement of non-compete clauses.

Serial entrepreneurs, i.e., entrepreneurs who had started other ventures beforehand, constitute another important source of new ventures. Gompers et al. (2010) estimate that in the 1990s in the US, approximately 10\% of all VC-backed founders were serial entrepreneurs. They find that previously successful serial entrepreneurs also have a higher success rate in their current venture, but that previously unsuccessful serial entrepreneurs have similar odds than first-time entrepreneurs. They provide evidence that entrepreneurial skills, especially for timing the market, help explain this performance persistence. However, they find no evidence that serial entrepreneurs obtain better valuations for their second ventures. Several papers find results that extend but also contrast with these findings. Hsu (2007) shows that serial entrepreneurs are more likely to obtain venture finance, but also that they obtain better valuations. Bengtsson (2011a) shows that only one in three serial entrepreneurs return to their previous $\mathrm{VC}$ investors for funding the new venture. He explains this result on the basis of a mismatch between the serial entrepreneur's new opportunity and the expertise of the VC from the prior venture. Paik (2010) examines VC-backed companies in the US semiconductor industry and finds that serial 
entrepreneurs have lower success rates than first-time entrepreneurs. However, he finds some evidence of learning, where serial entrepreneurs seem to be able to survive for longer. ${ }^{5}$

The ability of serial entrepreneurs to secure funding, especially following failure, may differ across countries. Landier (2006) provides a theory of how a stigma of failure may become a self-fulfilling prophecy: if the environment is forgiving of failure, higher ability individuals are willing to start risky companies, and the pool of failed entrepreneurs contains enough high ability entrepreneurs to warrant financing their next venture. However, if the environment is unforgiving, only low ability individuals are willing to start risky companies, and the pool of failed entrepreneurs consists of low ability entrepreneurs that cannot be financed profitably.

Another perspective on the sources of deals is to ask what types of opportunities are suitable for VC financing. A management literature describes the criteria typically used by VCs (MacMillan et al., 1985; Hall and Hofer, 1993; Eckhardt et al., 2006). Economists instead mostly focus on market characteristics. Brander and De Bettignies (2009) use a dynamic predator-prey model to explain the cyclical patterns of VC investments. In their model VCs invest on the basis of sector opportunities as well as their sector experience. Making investments depletes the stock of sector opportunities but increases the VC's sector experience. This creates dynamic imbalances and cyclicality of investments. Nanda and Rhodes-Kropf (2010) introduce the notion of financing risk within a given sector. They use a model with staged financing (see also section 3.3.2) where the early investors are uncertain about how many others would want to continue investing in the company's sector. In their model rational investors sometimes switch from one

\footnotetext{
${ }^{5}$ Chen (2009) proposes a methodology for disentangling selection and learning effect. Using data from the US National Longitudinal Survey of Youth (which captures a much broader set of entrepreneurs than those that obtain $\mathrm{VC}$ finance), she find evidence in support of skill selection.
} 
sector to the other, even without a change of fundamentals. They show that companies with high option value are particularly harmed by such investments cycles. ${ }^{6}$

Overall, we would argue that while there is some recent research on spin-offs and serial entrepreneurs, we still know relatively little about the creation of ventures that demand VC finance. Somewhat surprisingly, there seems to be no dialogue between the VC literature and the labor economics literature on the decision to become an entrepreneur. Kerr and Nanda (2011) provide a useful overview over this literature that mostly focuses on self-employment. The challenge is to see how this broader labor literature helps to understand the origins of VC deals. A similar comment applies to the integration of research on industry dynamics with the VC literature.

\subsubsection{The choice between venture capital and alternative funding sources}

What types of ventures are financed by VCs? Puri and Zarutskie (2011), using US Census data, find that only $0.11 \%$ of new companies created over a 25 year sample period from 1981-2005 are funded by VC, increasing to $0.22 \%$ over the period $1996-2000$. This general finding is confirmed in other sub-samples over time. In the Kaufmann Survey less than 1\% of all start-up raise any funds from VCs (Robb et al. 2010). Berger and Udell (1998) find that in the National Survey of Small Business Finances, $2 \%$ of the amount of equity financing is provided by VCs. VC investments are also concentrated in a few high technology sectors with rapid growth opportunities. ${ }^{7}$ However, in terms of employment Puri and Zarutskie (2011) report that VCbacked companies accounts for $5.3 \%$ to $7.3 \%$ of employment in the US, compared to

\footnotetext{
${ }^{6}$ In a related vein, Cumming et al. (2005a) argue that IPO cycles also affect the choice of projects VCs want to finance.

${ }^{7}$ Amit et al. (1998) argue that while VCs naturally focus on industries where information asymmetries are high, within these industries they prefer to finance firms that have relatively milder information challenges.
} 
approximately $2.7 \%$ for the period 1981-1985. And in terms of IPOs, Ritter (2011) reports that between 1980 and 2010, 35\% of all US IPOs were VC backed.

We now compare $\mathrm{VC}$ financing against its alternatives, looking first at banks and then at angel investors. One obvious difference between VCs and banks is that VCs use equity-like securities whereas banks use debt. de Bettignies and Brander (2007) argue that another critical distinction between VCs and banks is that only VCs provide value-adding services (we discuss these in section 3.3.). They argue that, when both entrepreneur and VC provide private effort, VCs optimally use equity in order to balance the incentives for both parties. With banks as passive investors, only the entrepreneur's incentives matter, so that banks optimally use debt which preserves the entrepreneur's upside incentives. VC financing is worthwhile whenever the marginal value of $\mathrm{VC}$ effort is sufficiently high.

While de Bettignies and Brander assume that VCs have greater capabilities than banks after the investment, Ueda (2004) assumes that VCs have greater capabilities before the investment. In her model banks screen imperfectly and need to rely on high collateral to finance the entrepreneur. VCs can perfectly screen, but they are assumed to be able to partly appropriate the idea. The model predicts that VCs will finance companies with higher returns and also higher risk. Entrepreneurs also seek VC financing when they have little collateral and when they require larger investment amounts.

Landier (2003) explains the choice between VCs and banks in terms of the consequences of terminating the business, and of the hold-up problem prior to termination. If the entrepreneur faces a large stigma of failure after termination, it is important to protect her from hold-up by investors. The paper shows that long-term financing without investor control prevents such holdup. He associates this equilibrium with banks. If, on the other hand, the entrepreneur can easily 
threaten to abandon a venture, then it is the investor who needs to be protected from being held up by the entrepreneur. In that case, investors provide staged financing (i.e. a sequence of shortterm financings, see section 3.3.2) and hold significant control rights. Landier associates this equilibrium with VCs. He also shows how there may be multiple equilibria, where entrepreneurs only start high risk ventures if $\mathrm{VC}$ are there to finance them, and vice versa. Winton and Yerramilli (2008) also focus on an interim decision between termination and refinancing, but allow for two possible continuation strategies, one conservative, and the other risky. They assume that VCs have better monitoring capabilities than banks, so that only VCs can correctly identify whether the risky continuation strategy is warranted. VCs also have a higher cost of capital due to the illiquid nature of their capital. The main prediction of the model is that $\mathrm{VC}$ funding becomes optimal when there is a big difference between the risky and conservative strategy, and when the returns are sufficiently skewed so that there is a low probability of a high return, and a high probability of a low liquidation value.

A related theoretical literature looks at the choice between $\mathrm{VC}$ and angel financing. Chemmanur and Chen (2006) argue that VC can add value, but angels cannot. Their model also includes asymmetric information that gets resolved over time, and explains why some entrepreneurs start with angel financing but switch to VC at a later stage. Schwienbacher (2009), on the other hand, argues that angels and VCs can both play value-adding roles, but that the key difference is that VCs have sufficient capital to refinance a company, whereas angels don't. Because of the need to attract other investors at a later stage, angels actually provide more effort than VCs. Entrepreneurs trade off higher investor effort against greater refinancing risk (see also Schwienbacher, 2007). 
Kerr et al. (2011) use a unique database to assess the role of angel funding for the growth, survival, and access to follow-on funding of high-growth start-up companies. They use a regression discontinuity approach and find a strong positive correlation of angel financing on the growth and survival of companies.

There is surprisingly little empirical evidence on the choice between VC and bank funding. Berger and Schaek (2011) report results from a 2001 survey of small business financing in Italy, Germany, and the UK. They find that $58 \%$ of companies obtain bank funding and $6 \%$ obtain VC. Their sample comprises SMEs rather than start-ups, with the average VC-backed company being 21 years old. Their main result is that companies that obtain VC may also have a main bank, but that there is a negative correlation between the presence of a $\mathrm{VC}$ and the amount of bank funding. Survey responses suggest that VCs provide expertise that is different from that provided by banks. Moreover, VC-backed companies are less likely to have multiple banking relationships. This can be interpreted as indirect evidence that companies choose VC funding to avoid being held up by banks. This last result presents a twist on the theories of Ueda and Landier, both of which argue that hold-up occurs only with VC and not with bank financing. While most theories assume that some external funding is essential, Amit et al. (1990) examine model where entrepreneurs choose between VC funding against no external funding. In the presence of asymmetric information, better entrepreneurs may prefer no funding over VC funding. If it is possible to invest in a visible signal of quality that reduces the asymmetric information (e.g., a prototype) some entrepreneurs may do so, although the best quality entrepreneurs may not necessarily do so. Entrepreneurs may also want to invest in a signal that certifies quality. 
Concerning empirical research on angel financing, Prowse (1998) provides some preliminary descriptive data. Goldfarb et al. (2009) exploit a unique dataset of the records from a failed law firm whose clients included both VCs and angels. They find that for smaller financing amounts, all combinations of sources of finance are feasible. For larger financing amounts some VC participation is required, and is associated with stronger investor control rights. They also find that angel and VC deals have similar success rates when the amounts involved are smaller, but that angel-backed companies are more likely to become 'living dead'. Pure VC deals have a higher success rate when they involve larger sums. They conclude that entrepreneurs looking for more patient and less control-oriented investors seek angel financing whereas entrepreneurs looking for more managerial value-adding choose VCs, with intermediate cases mixing angel and $\mathrm{VC}$ funding.

Overall we would say that the trade-offs between VC, banks and angel financing still remain poorly understood. The same holds for the trade-offs that determine when companies should start looking for (different forms of) external finance. While there are several theories, there is no clear consensus on what the main assumptions should be and where the key differences lie. This is partly due to the lack of clear empirical facts that might help to focus this literature. We expect that progress will come from credible datasets that help to establish more clearly how these three types of financing compete and complement themselves.

\subsubsection{The choice among venture capital firms}

How are different entrepreneurs matched with different VCs? In terms of theory, this is a search and matching problem. Inderst and Müller (2004) and Silveira and Wright (2006) consider search model models where homogenous agents are matched. Plehn-Dujowichy et al. (2011) allow for heterogeneous types and ask how assortative matching affects pricing and deal 
structures. ${ }^{8}$ Casamatta and Haritchabalet (2011) consider a model where entrepreneurs chose whether to bargain with one or two VCs, and explore a trade-off between higher probabilities of obtaining financing versus more favorable deal terms.

A few recent papers empirically examine the matching process. Bottazzi et al. (2011) examine investments by European VCs, focusing on cross-country investments and examine deal formation constructing a sample that includes not only the realized deals but also a sample of potential deals. They focus on the Eurobarometer trust measure, which measures the level of generalized trust that citizen of country express for the other. Their main finding is that generalized trust explains deal formation even after controlling for a large number of alternative factors, including investor and company fixed effects. ${ }^{9}$ Using a similar empirical approach for US data, Bengtsson and Hsu (2010) focus on the human and social characteristics of the individual entrepreneurs and VC partners. They find that ethnic similarity increases the likelihood of investment. Similarity in terms of attendance at top universities also predicts deal formation. VC partners' expertise, however, seems to matter mainly for the stage they invest in, but not for the particular companies they pick. Shane and Stuart (2002) also find that 'social capital', specifically having direct or indirect ties with VCs, increases the likelihood of obtaining VC financing.

This literature establishes the importance of social capital determinants, such as trust, ethnicity and network ties, for the matching of entrepreneurs and investors. What remains largely an open question is how much these social criteria substitute or complement the characteristics of the underlying business opportunity. Kaplan et al. (2009) indirectly look at this by examining the relative importance of the entrepreneur's idea (the 'horse') versus the entrepreneurial team (the

\footnotetext{
${ }^{8}$ Sørensen (2007) also assumes assortative matching for his identification strategy; see the discussion in section 2.

${ }^{9}$ See also Duffner et al.(2009).
} 
'jockey'). Their main conclusion is that ideas matter more because companies' strategies change rarely, whereas management turnover is common.

\subsection{Contracting}

\subsubsection{Theories of optimal cash flow and control rights}

VC contracts (also called term sheets) have proven to be a rich hunting ground for contract theorists, as reflected by the large number of papers in this area. While VC term sheets contain many clauses, theorists took particular interest in explaining the use of convertible preferred equity (CPE henceforth). This security combines a debt-like preferred security with an option to convert into an equity-like security. Investors benefit from the preferred terms when the exit value is low (i.e., on the downside) but convert to common equity when the exit value is high (i.e., on the upside). There are several types of CPEs, differing in the way that the downside claim is structured. While model details vary, most theories explain the use of CPE as an optimal incentive structure between entrepreneur and VC. The entrepreneur typically faces some moral hazard problem, modeled either as private effort or as private benefit. The debt-like claim in the downside provides incentives for the entrepreneur to exert effort or exert restraint in capturing private benefits. As active investors, VCs also need to be given incentives, since their actions are by their nature non-contractible (i.e., they cannot be enforced in court). Theories therefore differ mostly in terms of the role of the VC: some models focus on the VC's effort incentives (resulting in a double moral hazard model); some focus on the VC's decision to refinance or liquidate the venture at an intermediate point in time; and some focus on the VC's control rights (i.e., the rights to exert control over a portfolio company's decision making). We examine these three approaches in turn. 
First, Schmidt (2003) examines a double moral hazard model where the entrepreneur provides effort first and the $\mathrm{VC}$ second. Without conversion the $\mathrm{VC}$ has a preferred payoff which is capped by the security's face value and provides few incentives for adding value. With conversion, instead, the VC has stronger equity-like incentives. In his setup, the entrepreneur works hard so that the $\mathrm{VC}$ can see enough upside potential to convert and become a common equity holder. The optimal CPE is such that the $\mathrm{VC}$ only converts if the entrepreneur has provided the optimal level of effort.

Casamatta (2003) also considers the possibility that in addition to the entrepreneur some outsider can provide non-contractible value-adding advice. She shows that the provision of advice creates information rents. She shows that the provision of financing should be linked to advice, and that CPE is the optimal security whenever the required investment amount is sufficiently large. ${ }^{10}$

Hellmann (2006) uses a double moral model that distinguishes between two exit events: acquisitions, where the venture is sold to a third party so that incentives for the original founders no longer matter, and IPOs where the entrepreneur remains involved so that his incentives continue to matter. He shows that the optimal contract preserves the entrepreneur's equity in case of IPO, but allocates additional cash flows (i.e., rights to the income produced by the company) to the $\mathrm{VC}$ in case of acquisition. The optimal contract can be implemented using $\mathrm{CPE}$ with the additional (empirically relevant) feature that conversion is automatic in case of IPOs but not acquisitions. ${ }^{11}$

\footnotetext{
${ }^{10}$ Two extensions are worth mentioning. In Schindele (2006) the VC may perform two types of task, one congruent (value-adding) and one dissonant (monitoring). And Inderst and Müller (2009) develop a theory that suggests that value-added investors are more valuable in industries with intense competition or learning by doing.

${ }^{11}$ Bascha and Walz (2001) and Hellmann (2003) develop related models where CPE is used to achieve optimal exit decisions. These models are based on two-sided private benefits, rather than two-sided moral hazard.
} 
For the second type of model, several papers focus on the VCs decision between terminating versus refinancing the venture. Repullo and Suarez (2004) use a double moral model where there is a refinancing event at some intermediate stage. They argue that in a world where interim signals about firm quality are not verifiable the optimal contract resembles a CPE. In a related vein, Dessí (2005) examines how optimal contracts ensure efficient refinancing decisions, while at the same time providing incentives for a $\mathrm{VC}$ to monitor. The optimal contract also prevents collusion between the entrepreneur and the $\mathrm{VC}$, at the expenses of all other investors.

Bergemann and Hege (1998) use a (one-sided) continuous time moral hazard model where the VC learns from the entrepreneur's investments. The entrepreneur has an incentive to use funds for private benefits rather than for learning about the opportunity. The optimal incentive contract resembles CPE, where the preferred claim balances the beneficial effect of termination (in terms of improving incentives for the entrepreneurs), with the inefficiency of termination (in terms of the entrepreneur's loss of private benefits). Bergemann and Hege (2005) extend the model to allow for a comparison of relationship finance with arms' length finance. Marx (1998) obtains similar results in a simpler static framework. In both of these papers, a combination of debt and equity can also be used instead of CPE.

Cornelli and Yosha (2003) consider a refinancing game, but focus on a different moral hazard problem where the entrepreneur can engage in inefficient 'window dressing', i.e., the manipulation of a signal at an intermediate stage. In their model the optimal contract prevents this inefficiency by forcing the investor to make an irreversible choice between a downside and upside security. Their optimal contract is best interpreted as convertible debt with a fixed conversion deadline, rather than traditional CPE which typically has no conversion deadline. 
The third type of model interprets $\mathrm{CPE}$ as a contingent control structure, where the VC holds greater control rights prior to conversion (when the VC's claim is debt-like) than after conversion (when the VC's claim becomes equity-like). Berglöf (1994) uses an incomplete contracting framework where it is efficient to give control rights to the investor in the bad state, but to the entrepreneur in the good state. ${ }^{12}$ Cestone (2002) develops a model along similar lines, showing that, contrary to standard corporate finance theory, control rights may be allocated not to the pure equity holder (the entrepreneur), but to the VC who holds CPE. A limitation of this class of models is that they directly associate CPE with contingent control rights, when in fact VC contracts allocate cash flow and control rights separately (Kaplan and Strömberg, 2003). In practice, the $\mathrm{CPE}$ contract allocates voting rights to the investor on an as-if-converted basis. Contrary to the above model assumption, conversion only happens at exit, and does not by itself constitute a loss of $\mathrm{VC}$ control rights.

Beyond the quest to explain CPE, several papers examine how control rights should be optimally structured, and how they relate to the optimal allocation of cash flow rights. Hellmann (1998) derives the optimality of VC control in a model where VCs are concerned about being held up by the entrepreneur. VCs can add value by finding superior managers, but will only do so if they have the right to replace the founding manager. Gebhardt and Schmidt (2006) extend this analysis in a model where the need to replace the manager depends on the state of nature at an intermediate stage. Aghion et al. (2004) focus on a separate but related issue, namely the design of exit options. They note that VC contracts include control rights that pertain to the VC's ability to exit and obtain liquidity on the investment. They argue that lack of liquidity may

\footnotetext{
${ }^{12}$ Chan et al. (1990) obtain a similar result in a two-period model where there is learning about the entrepreneur's type.
} 
provide good incentives for active monitoring, but that it also imposes a cost onto the $\mathrm{VC}$ that is ultimately passed on to the entrepreneur.

In the above models the allocation of control affects the ex-post bargaining game between VC and entrepreneur because ex-ante there is symmetric information. By contrast, Dessein (2005) examines the allocation of control rights in the presence of ex-ante asymmetric information. In his model the entrepreneur's willingness to cede control is a signal to the VC how much preferences are aligned.

One limitation of the control rights approach is that it typically rests on a discrete choice between giving control either to the entrepreneur or the investors. Kirilenko (2001) tries to move away from this by using a non-standard definition of control rights that effectively captures private benefits rather than decision rights. More convincingly, de Bettignies (2008) explores a model where joint control is an alternative to either entrepreneur or VC control. He finds that such joint control goes hand-in-hand with equity-like contracts, in situations where there is high complementarity between the efforts of the entrepreneur and VC. Broughman (2008) proposes yet another approach by examining the role of independent directors as arbitrators between the entrepreneur and VC. Finally, Gilson and Schizer (2003) provide a rationalization of CPE based on taxation. Their argument is that the use of CPE for investors enables common stock holders (i.e., founders and employees) to defer taxation and to be taxed at capital gains tax rates, which are usually lower than income tax rates.

Overall, there is no shortage of theories to explain the allocation of cash flow and control rights in VC. Despite the variety of modeling assumptions, the literature provides a fairly consistent set of explanations. It would certainly be possible to add further explanations, most notably behavioral ones, but it is unclear how much additional insight can be gained from this. 
Where the literature probably falls short is explaining why and how the identity of investor and the nature of legal enforcement - both found to be relevant in the empirical literature discussed below - affect optimal contract choices.

\subsubsection{Empirical evidence on venture capital contracts}

In two seminal papers, Kaplan and Strömberg $(2003 ; 2004)$ empirically examine the structure of VC contracts. ${ }^{13}$ The 2003 paper is based on an examination of term sheets from 14 US VC firms, making 213 investments into 119 companies. The first part is descriptive, mapping out the frequencies of different types of securities, control structures and other contractual clauses. Contracts routinely separate cash flow and control rights, make extensive use of state contingent clauses, control tends to shift to the VC (entrepreneur) in bad (good) states of natures. In the second part, they evaluate a variety of financial contracting theories. Overall they find that principal-agent and control-based theories perform relatively well, whereas 'stealing' theories based on unverifiable cash flows do not fit the evidence. They also find that investor-friendly cash flow and control rights tend to be complements, not substitutes.

Kaplan and Strömberg (2004) ask why VCs use certain clauses in certain deals. For a subsample of 67 deals, they obtain investment memoranda that summarize the qualitative information collected by the VCs as part of their due diligence. From this they extract three sources of risk: "internal risk" concerning the abilities of the founders and the difficulties of observing their actions, "external risk" concerning uncertainty on the business environment that are beyond the company's control, and "execution risk" concerning the venture's reliance on the founders, and any resulting potential for hold-up. They find that higher internal and external risks are associated with more $\mathrm{VC}$ control and more contingent compensation, whereas execution risk

\footnotetext{
${ }^{13}$ See Trester (1998) and Gompers (1999) for some earlier work.
} 
is related to the vesting of founder shares. One unique feature of the investment memoranda is that they also contain some information about the expectations that VCs have concerning the level of control and value-adding that they can provide. ${ }^{14}$ Kaplan and Strömberg find that anticipation of control actions (such as founder replacement) is associated with greater VC control rights, whereas anticipation of value-adding activities is associated with larger VC equity stakes.

A number of papers look at how investor characteristics affect contracts. Bengtsson and Sensoy (2011a) find that higher ability investors make less use of contractual clauses to protect their returns on the downside, where ability is proxied by experience. Bengtsson and Ravid (2011) find that companies and VCs in California also use considerably less downside protection; this is also the case when the VC is physically closer to the company. Furthermore, Bengtsson and Bernhardt (2011a) argue that contracts vary relatively little within VC firms, and Bengtsson and Bernhardt (2011b) show that contracts are influenced by the choice of lawyers. Moving the analysis to the dynamics of contracting, Bengtsson and Sensoy (2011b) study how contracts evolve as companies secure new rounds of financing. They find that following poor company performance, the contracts for the new investors include more downside protection and the contracts of the previous round investors are more likely to be renegotiated. Finally, Bengtsson (2011b) shows that covenants are more likely in contracts that also include higher fixed claims on the downside. Garcia-Appendini et al. (2011) find a positive relationship between the use of covenants and investment returns.

There is some work that considers the compensation of executives in VC backed companies. Wasserman (2006) notes that founder-CEO receive lower cash compensation than

\footnotetext{
${ }^{14}$ In section 3.3 we discuss the literature that looks at what actually happens in terms of these control and valueadding activities.
} 
non-founder-CEOs, although they have higher ownerships stakes in the venture. The differences in cash compensation also diminish over time. Bengtsson and Hand (2011) find that CEO compensation is linked to fundraising, so that CEOs get rewarded for raising additional financing rounds. ${ }^{15} \mathrm{~A}$ few papers also consider employee compensation in VC-backed companies. Hellmann and Puri (2002) first noted that VC funding is associated with the adoption of stock option plans. Bengtsson and Hand (2011) further show that stronger VC control is associated with more generous option plans. ${ }^{16}$

The empirical work mentioned so far is based on US contracts. The question arises to what extent these contractual features are country-specific. Lerner and Schoar (2005) employ a hand-collected sample of 210 private equity deals made in emerging economies. They find that in countries with civil law origins (and also in countries with lower legal enforcement) contracts are more distinct from the U.S. standard. They argue that these contracts are also further away from a theoretically optimal solution. Kaplan et al. (2007) also document differences in contractual features in cross-country investment, using a hand-collected sample of 145 European deals. They note that the use of sophisticated contracts (using downside protection, contingent control, etc...) is higher in common law countries. However, they show that this effect disappears once they introduce variables that measure the investor's experience with US-style contracting. Bottazzi et al. (2009) develop a model where optimal contracts and investor actions depend on the quality of the legal system. The model predicts that intermediaries from countries with a better legal system provide more support to their companies, even when investing abroad. Using survey data on contracting and actions for 1,652 European deals, they find that with better legal protection, investors give more non-contractible support and demand more downside

\footnotetext{
${ }^{15}$ See also Baker and Gompers (1999) for evidence on CEO compensation at the time of the IPO.

${ }^{16}$ Hand (2008) provides further evidence on the structure of employee option plans in VC backed companies.
} 
protection. They also find that the investor's legal system is more important than that of the company in determining investor behavior. Using the same data, Bottazzi et al. (2011) further find that when investing in foreign countries, VCs use more sophisticated contracting when there is higher bilateral trust between their countries. Balcarcel et al. (2010) explore the factors that shape cross-border investments. They find that the company's country legal system has little effect on contractual features, but that investment flows and round size increase with the quality of legal enforcement. They then build a measure of contracting frictions that is negatively correlated with cross-border investment flows. They argue that contracting can overcome the shortcomings of a country's legal system but only to the extent allowed by the quality of legal enforcement.

Overall, these empirical studies have made large strides into verifying the theories of VC contracting. They also identified a number of additional effects that may stimulate further theoretical and empirical research. One challenge for this literature is to assess the impact that contracting choices have on economic outcomes. The complicating factor here is that (as discussed in section 2) contracts are endogenously chosen. If we empirically find a correlation between contracting clauses and performance differences, this may be due to unobserved differences across VCs and companies rather than to suboptimal contracting choices. We therefore emphasize that to make further progress on understanding the consequences of contracting we have to simultaneously understand the determinants of these contracting choices too. Finally, we note that relatively little is known about debt in VC companies. For example, there are several specialized banks that offer so-called "venture debt". And seed investors sometimes make use of convertible debt that converts upon receipt of a first $\mathrm{VC}$ round. 


\subsection{Post-investment}

\subsubsection{Value-adding services}

A key feature of VC financing is that investors take an active role in the companies they finance. The theories discussed in section 3.2 identify two broad types of activities: value-adding services and control actions. The main difference between the two is that value-adding activities are likely to benefit the company and the founder(s) alike, whereas control functions benefit the company, but possibly at the expense of the founder(s). In this section we discuss the empirical evidence that directly looks at the post-investment activities of VC investors. The broader question of how VCs create social value will be addressed in section 6 .

The early work by Sahlman (1990) and Gorman and Sahlman (1989) shows that VCs spend a lot of time with their portfolio companies, sitting on the board of directors, mentoring founders, working on raising additional funds, recruiting management and providing strategic analysis. ${ }^{17}$ Lerner (1995) was the first to provide systematic company-level evidence on such VC activities. He documents that VCs increase their presence on the board of directors at the time that companies replace their CEO; VCs are more likely to take a board seat the higher is their geographic proximity with the company.

Hellmann and Puri (2002) use a hand-collected data set of Silicon Valley companies that contains both VC-backed and non-VC-backed companies (financed mostly by angels and corporate investors). Analyzing several organizational practices, they find that $\mathrm{VC}$ is associated with a pattern of professionalization. For example, VC-backed companies use more professional hiring practices, are more likely to adopt stock option, and are faster to hire a VP of marketing. Using a duration model, Hellmann and Puri find that the likelihood of replacing a founder with a

\footnotetext{
${ }^{17}$ See also Sapienza (1992) and Sapienza and Gupta (1994).
} 
professional CEO more than doubles when VCs first finance the company. They also distinguish between 'friendly' turnovers (where the founder remains involved with the company) from 'unfriendly' turnover (where the founder severs all ties) and find evidence of both types.

Further examining the transition from founder to outside CEO, Wasserman (2003) finds that founders of high tech companies are more likely to be replaced when they raise additional rounds of financing, something that he calls the "paradox of entrepreneurial success". Kaplan et al. (2010) further examine what characteristics matter for the CEO choice. They find that both general ability and execution skills matter. After controlling for skills, they find no performance differences between insider versus outsider CEOs.

Bottazzi et al. (2008) examine the determinants and consequences of VC value-adding activities, using survey-based evidence from European VC deals. They find that VC firms with partners that have prior business experience (as entrepreneurs, managers or consultants) are more likely to be more active investors. Moreover, partners' professional background helps explain the degree to which they are put in charge of portfolio companies. Independent partnerships are more active than captive VC firms operated by corporations or banks. They further examine the effect of value-adding activities on the probability of successful exit. After accounting for the fact that weaker companies are more likely to seek value-adding VCs, they find a positive effect of active $\mathrm{VC}$ involvement on successful exit. ${ }^{18}$ The unique feature of this work is that it attempts to measure the value-adding effects directly, by looking at actions taken in specific companies. ${ }^{19}$

A common challenge in these studies is separating selection from treatment effects (see also section 2). Sørensen (2007) develops a theoretical framework that assumes so-called

\footnotetext{
${ }^{18}$ Zarutskie (2010) also looks at the role of partners' human capital in first time funds.

${ }^{19}$ In section 6 we discuss a broader literature that examines the effects of $\mathrm{VC}$ on innovation, employment and other measures of economic output. This literature typically infers a value-adding effect indirectly through the effect of $\mathrm{VC}$ on outcomes.
} 
"assortative" matching, where more experienced VCs match with higher quality entrepreneurs. He then infers the value-adding effects of different VCs through their impact on exit probabilities. Estimating his matching model structurally using Bayesian methods, he finds evidence that both matching (i.e., selection) and $\mathrm{VC}$ involvement (i.e. treatment) contribute to exit performance.

Hsu (2004) uses hand-collected data from companies that received multiple VC offers, allowing him to compare how valuations of the same company differ across VCs. He finds that high-reputation VCs offer lower valuations, and that entrepreneurs prefer low-valuation-highreputation offers over high-valuation-low-reputation alternatives. This shows that entrepreneurs themselves believe that it is worth accepting lower financial returns in return for working with a higher quality VC. The study therefore provides indirect but convincing evidence of a valueadding role of VCs. ${ }^{20}$

Overall we would say that the literature so far has managed to shed some light onto the difficult-to-observe processes by which VCs can add value to their companies. While considerable emphasis has been placed on a clean econometric separation of selection versus treatment effects, these efforts seem to ignore forward-looking selection effects, where certain companies seek out certain VCs precisely because of their expected value-added services. As a consequence traditional selection models may understate the importance of value-adding effects. Nonetheless the literature continues to find robust treatment effects even after extensive controls for selection. The literature however remains incomplete in several ways. For example, little is known about how value-adding differs across countries, with the exception of Bottazzi et al.

\footnotetext{
${ }^{20}$ See also Fitza et al. (2009), who employ variance decomposition analysis to identify selection and treatment effects. Baum and Silverman (2004) use a Heckman correction term for separating treatment and selection effects in a sample of Canadian companies that go public in the 1990s.
} 
(2009). Also, we are still largely ignorant on how value-adding is related to other aspects of the deal structure, such as contracts, syndicates or the staging of investments.

\subsubsection{The staging of venture capital investments}

Several theory papers consider the trade-off between providing all the necessary financing upfront versus "staged" financing where the initial financing only allows the venture to proceed to some interim date at which additional financing round is required. Sahlman (1990) argues that staging is an important instrument for controlling $\mathrm{VC}$ risk, allowing the investor to create optionlike returns. However, staging also creates potential conflicts between the entrepreneur, the initial investors (the 'insiders'), and potential new investors (the 'outsiders'). Admati and Pfleiderer (1994) provide a theory where investors only use common equity. They show that insiders have no conflict in revealing information truthfully and setting price fairly only if their percentage ownership remains constant before and after the financing, i.e., there is no dilution. This requires that investors invest at a constant fraction, where the percentage of insider funding in the new round equals the existing percentage of the insiders' ownership stake. Admati and Pfleiderer do not address whether the insiders actually want to invest a constant fraction. Fluck et al. (2005) note that at the time of the follow-up round, insiders have an incentive to finance the entire round by themselves, at terms that are unfavorable for the entrepreneur. They also show how that such self-dealing can have deleterious ex-ante incentive effect on the entrepreneur. First round VCs would in fact want to commit to having competitive pricing for later round financing.

While staged financing gives the early round VCs insider bargaining power, Neher (1999) argues that upfront financing would lead to a different problem, namely giving the entrepreneur a large hold-up opportunity. In his model the entrepreneur has hold-up power because he is assumed to be the only one who can implement the idea. Staging helps the investor 
to build collateral that limits the entrepreneur's hold-up power. Finally, Ray (2010) shows how staging is used as a screening device and explains why investment amounts should be increasing over time.

The first paper to empirically study the staging of VC investments is Gompers (1995). He argues that staging is related to expected agency costs, which are increasing with (i) the ratio of intangible to total assets, (ii) the value of growth options (measured by the market-to-book ratio), and (iii) asset specificity (measured by R\&D intensity). He finds that industry-level variation for these three ratios affects three measures of staging: investment amounts, duration between rounds and total number of rounds.

Tian (2011) asks whether staging and monitoring are substitutes by examining how staging decisions depend on the proximity between VC and company. He finds that staging is more likely when there is greater geographic distance between company and VC firm. He also finds that distant investments with more staging have the best exit performance. In a related vein, Balcarcel et al. (2010) examine how staging varies with the quality of the legal environment. They look at cross-country investments of US VCs and find that VCs make more use of staging when the company's country has better legal enforcement.

Bergemann et al. (2009) examine the dynamics of optimal staging decisions. They first build a continuous time theory model with learning, and then empirically test the model's predictions. Their findings are that investors initially contribute small amounts with an expectation to invest larger amounts later on, that they adjust the investment amounts according to interim information, and that they use more staging (fewer small investments) when the risk of failure is high. They validate the model with empirical evidence that shows that, among other 
things, that investment rounds are increasing over time, and that later round financing respond to interim information.

Bienz and Hirsch (2011) examine the trade-off between round-based financing, where the price per share is determined at the time of refinancing, versus milestone financing, where the investor typically has the option to invest at a predetermined price. They first provide a theory that shows that milestone financing is preferred whenever the entrepreneur has a weak ex-post bargaining position. They then test this hypothesis on a sample of German VC deals and find supportive evidence, showing that milestone financing is more often used by companies that lack access to outside investors.

Broughman and Fried (2011) provide some preliminary empirical evidence on insider rounds, studying 90 follow-on rounds by 45 VC-backed Silicon Valley companies that were sold in 2003 and 2004. They compare the valuation and returns from inside versus outside rounds. While insider rounds have lower valuations they also generate lower returns. They argue that these results are inconsistent with the insider hold up problem discussed above, but are consistent with an alternative theory of 'rescue financing', where insiders are the only ones willing refinance a company in difficult times.

Overall, the literature on staging has generated several interesting insights, but it also faces some methodological challenges. On the theory side, it should be noted that staging is an incomplete contract. It is possible to write more complete contracts, for example the initial contract could specify put or call options for future rounds. Little is known about the trade-off of adding more sophisticated clauses to the staging process. On the empirical side, the standard measures of staging do not measure the ex-ante intent of staging, but only ex-post realizations. As a consequence, it is difficult to distinguish staging behavior from underlying company 
performance. For example, observing more rounds or shorter intervals between rounds could be the result of deliberate $\mathrm{VC}$ staging, but it could also be the result of good performance in terms of a company meeting its milestones faster.

\subsection{Exits}

VCs can exit portfolio companies in multiple ways. The company can fail, it can be acquired or it can go public via an IPO. ${ }^{21}$ The literature on VC exits can be divided into two broad categories, only looking at the determinants of exit performance, the other focusing on the IPO process and the post-IPO performance of VC-backed companies.

\subsubsection{The determinants of exit performance}

As discussed in section 2, obtaining detailed cash flow data on venture investments is extremely difficult. Most exit studies therefore focus on type of exit, interpreting IPOs and acquisitions as success events, and considering it failure if the company closed down or remains alive after many year (the so called 'living dead'). Somewhat reassuringly, Puri and Zarutskie (2011) do not find any evidence that VCs disguise failures as acquisitions. Moreover, Phalippou and Gottschalg (2009) document that IPOs and acquisitions are indeed highly correlated with higher investor returns.

Using over twenty-five years of data from the Census Bureau, Puri and Zarutskie (2011) find that relative to the non-VC control group, VC-backed companies are more likely to go public, more likely to be acquired and less likely to fail. This basic pattern has generally been found in various subsamples over time. Amit et al. (1998) examine Canadian VC data to find that

\footnotetext{
${ }^{21}$ From a VC perspective it may also be possible to sell a company stake to another VC, in what is called a 'secondary direct' transaction. These transactions used to be rare, although they have become increasingly more important in recent years, due in large part to the dearth of IPOs Note that secondary directs may not represent an exit from the entrepreneur's perspective.
} 
most exits occur through management buyouts or acquisitions rather than IPOs, and that IPOs have higher returns than other forms of exit.

One would naturally expect that the achievement of company milestones correlates with exits. Cockburn and MacGarvie (2009) find that companies that have higher number of patents are more likely to receive VC funding and more likely to exit through an IPO or acquisition. Hsu (2006) finds that relative to the control group, VC-backed companies are more likely to engage in cooperative commercialization strategies (such as strategic alliances or technology licensing). They also have increased likelihood of going IPO, especially if financed by more reputable VCs. Ozmel et al. (2007) study young biotech companies and find that strategic alliances and VC financing both raise the hazard that the company goes public.

Exits may also be affected by the structure of VC contracts. Cumming (2008) examines the relationship between contracts and the choice between acquisitions and IPOs in a European sample. Consistent with the theories of Bascha and Walz (2001) and Hellmann (2006), he finds that acquisitions are more likely (and IPOs less likely) when convertible securities are used. Broughman and Fried (2010) find that there can be some renegotiation of the preferred terms at the time of acquisitions, especially if common shareholders have some power to obstruct the sale of the company. Bienz and Walz (2010) examine contract clauses about exit decisions, such as demand, piggyback or tag-along rights. They find that these rights always favor the investor, and are used more frequently when hold-up is more likely. Investor reputation is also routinely found to correlate with better exit performance. A large number of $\mathrm{VC}$ reputation measures have been used e.g., age, cumulative aggregate investment, number of investment rounds. Nahata (2008) compares different measures of $\mathrm{VC}$ reputation and relates them to multiple measures of company 
performance. He finds that a $\mathrm{VC}$ reputation measure based on cumulative dollar capitalization share of IPOs consistently predicts portfolio companies' performance.

Relationships and networks are also related to exit outcomes. Lindsey (2008) shows that strategic alliances are more common among companies that share a common $\mathrm{VC}$, and that such alliances are associated with higher exit rates. Gompers and Xuan (2009) find that when there is a common VC for the acquirer and target, a successful acquisition is more likely. The presence of a common VC affects how the purchase transaction is structured (with a higher stock component); how the market reacts to the announcement of the acquisition (more positively); and the acquirer's long run stock returns (higher). Sunesson (2009) finds that the likelihood that the portfolio company investment results in an IPO or acquisition increases by $42 \%$ when the VC and entrepreneur attend the same Top 3 academic institution in the past. Finally, the work of Hochberg et al. (2007) establishes a positive correlation between a variety of network measures and exit performance.

There may also be some reverse causality, where exit choices may affect the companies' strategic direction and the VC's investment strategies. Schwienbacher (2008) argues theoretically that $\mathrm{VC}$ financed start-ups choose their innovation strategies based on the investor's exit preferences. Gompers et al. (2008) show that changes in public market valuations, signaling changes in economic fundamentals, are important determinants of VCs' investments.

There is relatively little information about failures. The two main commercial VC databases - ThomsonOne and VentureSource - poorly distinguish between companies that are still operational versus failed. Using Census level data, Puri and Zarutskie (2011) find that VCbacked companies are less likely to fail but the difference between failure rates of VC and non- 
VC-backed companies is largely driven by lower initial failure rates of VC-backed companies. These results are also not just driven by the more reputable VCs.

Overall we would say that the literature provides clear evidence that VC-backed companies achieve better exits than most other start-up categories, and that there is a correlation between certain investor and company characteristics and these exit outcomes. What remains a significant challenge is attributing causal effects to any of these investor and company characteristics. There are also open questions about the relative importance of these different characteristics. Yet by far the biggest knowledge gap concerns the reasons for, timing of, and dynamics around company failures.

\subsubsection{The IPO process and post-IPO performance}

There is a large literature on the process of going public, and the performance of these companies, which is reviewed in Chapter XX of this Handbook. Here we limit our discussion to the part of the literature that directly deals with VC investments. One set of questions concern the timing of IPOs. Lerner (1994a), using a sample of 350 privately held venture-backed companies, establishes that VCs take companies public at market peaks and rely on private financings when valuations are lower. Lerner et al. (2003) further show how biotechnology alter their funding sources by relying more on public markets in times of rising markets, and relying more on strategic alliances in times of falling markets. Ball et al. (2011) also find that IPOs occur in periods when demand for growth capital is high. In a related early paper, Gompers (1996) identifies the phenomenon of "grandstanding" where younger VCs take companies public earlier than older $\mathrm{VC}$ in order to establish a reputation and raise capital for new funds. Lee and Wahal (2004) confirm these results even controlling for the endogeneity of VC funding. Neus and Walz (2005) provide an alternative theory for grandstanding behavior, in which less established VCs 
may want to take companies public, and may use underpricing as a device for credibly establishing reputation.

A number of papers study the role of VC backing at the time of the IPO. In one of the early papers Barry et al. (1990) examine VC-backed companies that go public in the period 1978-1987. They find that VCs hold concentrated equity positions in their portfolio companies, and continue to hold most of it a year later. They also serve on the companies' boards and generally continue to do so for more than a year after the IPO. Megginson and Weiss (1991) compare VC-backed IPOs with other IPOs over the period 1983 to 1987 and find that VCbacked companies have lower levels of underpricing and of gross underwriting spreads (charged by the underwriting bank). They also document that VCs retain a significant portion of their holdings in the company after the IPO. More recent papers confirm that VC-backed companies experience lower underpricing, once the endogeneity of VC funding is controlled for: Bottazzi and Da Rin (2011) use continental European data and Ellul and Pagano (2006) use British data. There is however not a full consensus, and results with US data seem to be different. Lee and Wahal (2004) find that VC-backed companies experience higher underpricing over the period 1980 to 2000, and particularly during the internet boom period (1999-2000). Liu and Ritter (2011) find that VC-backed IPOs are much more underpriced when they have coverage from allstar analysts, and argue that VCs allow higher levels of underpricing because they are especially concerned about analyst coverage when shares are distributed to limited partners. In equilibrium, the underwriters with the most influential analysts realize that they can win the mandate even with a low offer price.

Hoberg and Seyhun (2010) find that VCs who are more loyal and tolerate higher underpricing receive more marketing support and favorable analyst revisions. Bradley et al. 
(2011) argue that this effect applies primarily for top VCs (defined as the most active VCs, or VCs with the highest IPO success rate relative to others),

What if the venture capitalist is also the underwriter? There is a potential conflict of interest versus a certification effect which has been explored extensively in the banking literature when banks underwrite the companies to which they give loans. The early papers in this area are Kroszner and Rajan (1994); Puri (1994) who compare differences in long run performance, and Puri (1996) who compares the differences in pricing of securities ex-ante when banks underwrite the firms to which they lend. In a similar vein, Gompers and Lerner (1999a) look at long run performance, liquidation probability, and underpricing, and examine the effect of an underwriter in the IPO holding a venture stake. This comparison reveals that IPOs where the investment bank held an equity stake perform just as well, and by some measures significantly better than, nonaffiliated offerings. These results are similar to those found in the banking literature and are inconsistent with the existence of conflicts of interest.

A number of papers ask if $\mathrm{VC}$ involvement with portfolio companies has other effects on the company either at the time of the IPO or after. Lin and Smith (1998) find that while most VCs do not sell their holdings during the IPO, both their holdings and managerial involvement in the portfolio company decline thereafter. Those who do sell have well established reputations. Baker and Gompers (2003) find that VC-backed companies have fewer inside directors and more independent outsiders. Hochberg (2011) examines the effect of VC backing on the corporate governance of the company after the IPO. She finds VC-backed companies have lower earnings management, and more independent boards of directors. Agrawal and Cooper (2010) examine if VC backing and VC reputation matter in accounting problems in newly public companies. They find that VCs, especially reputable VCs, have positive influence as monitors on the financial 
reporting quality of companies that made an IPO. Wongsunwai (2011) examines the effect of VC quality on earnings management in companies that went public. He finds that after the IPO, companies backed by higher quality VCs have lower abnormal accruals, lower earnings management and lower likelihood of financial restatement. Lee and Masulis (2011) examine earnings management for companies that go public. They find more reputable investment banks are associated with less earnings management. They do not find that VC investment or backing by more reputable VCs restrains earnings management by companies that went public.

Even after the IPO, VC may have private information that they may use for timing their sale or distribution of shares. Brav and Gompers (2003) examine lock-ups in IPOs and find that venture capital backed IPOs have shorter lock-ups. They also find a significant drop in price when lockups expire consistent with a downward sloping demand curve. Gompers and Lerner (1998a) examine VC distributions and find that the share price valuation is highest around the time that the VCs distribute shares consistent with the view that VCs have inside information that they use to time stock distributions.

Several papers examine the subsequent price performance of companies that go public. Loughran and Ritter (1995) find a long run underperformance effect for companies issuing either an IPO or seasoned offering. Brav and Gompers (1997) investigate the long-run underperformance of VC-backed and non-VC-backed IPOs and find that in general VC-backed IPOs outperform non-VC-backed IPOs. They document that the long-run underperformance comes primarily from small, non-VC-backed public companies. Krishnan et al. (2011) examine post-IPO performance and find $\mathrm{VC}$ reputation is positively associated with long run company performance. It runs out that these performance results are very sensitive to the choice of sample period. Ritter (2011) provides the most recent numbers on long-run performance, showing that 
up to 1998 VC-backed companies tended to outperform others, but that this pattern reversed since then.

Looking beyond the US, Bottazzi and Da Rin (2002) study a sample of 540 companies that went public on three of Europe's then 'new' markets for technology companies; controlling for the endogeneity of VC backing they find that the post-IPO operating performance of VCbacked is not significantly different from those of other public technology companies. Ber and Yafeh (2005) examine high-tech Israeli companies and find that VC-backed companies have higher pre-IPO survival than other companies but do not differ substantially on post-IPO performance. Tykvová and Walz (2005) examine IPOs on Germany’s stock market for young technology companies (the now defunct Neuer Markt) and find that companies backed by independent VCs-backed companies have significantly better long run performance than other IPOs. However, companies backed by public VCs showed underperformance relative to IPOs with VC backing.

Johnson and Sohl (2011) ask whether in addition to VC, angel financing matters at the time of an IPO. They take a sample of IPOs from 2001-2007 and extract from the prospectus the presence of angel investors. $62.3 \%$ of firms that went public had angel investors, and $13.4 \%$ had only angel investors as their only significant outside shareholders. The authors find greater underpricing for VC-backed companies than for angel investor backed companies.

Overall we would say that while there is a substantial body of research that examines the role of VCs in the process of going public and the long-run performance of VC-backed IPOs, there are relatively few results that remain valid across time and geography. Probably the most persuasive evidence concern VCs' ability to time the market, both in terms of taking companies public, and in terms of disposing of their shares. Relative little is known about the role of VCs in 
their companies after going public, and the impact that their ultimate withdrawal has these companies. IPOs were the most important exit mechanisms in the US up to about 2001, but they seem to have played a much smaller role since then, and they rarely played a large role outside the US. As a consequence we would argue that more research on alternative exit mechanisms, most notably acquisitions and secondary sales, is warranted.

\section{Section 4: The analysis of venture capital firms}

In this section we examine the structure and strategies of VC firms themselves. We consider differences in organizational structures, investment strategies, the interrelationships among $\mathrm{VC}$ firms, and the way that they interact with their own investors.

\subsection{The organizational structure of venture capital firms}

The most important aspect of the organizational structure of VC firms concerns their type of ownership. Independent VCs invest on behalf of institutional investors and wealthy individuals. Captive VCs (see sub-section 4.1) have alternative ownership structures that affect their funding and strategic directions. Corporations, banks and governments are the three main types of captive VC firms. Corporate venture capital is the term used to refer to corporations making venture capital investments, either directly from their balance sheet or through a whollyowned subsidiary (e.g., "Intel Capital"). Banks can use similar structures to invest in venture capital (e.g., Citigroup’s “Citi Venture Capital International”). Governments can also operate wholly-owned venture capital funds, typically through a development bank (e.g., "Business Development Bank of Canada"). Alternatively government can provide capital through a variety of indirect programs (e.g., Australia’s “Innovation Investment Fund program”). Captive VCs account for a substantial portion of investments, especially outside the US. The various venture 
capital associations (NVCA, EVCA, etc...) regularly provide detailed statistics about their relative market shares.

\subsubsection{Corporate venture capital}

A fast growing body of literature examines the economics of corporate venture capital (CVC henceforth). Early theory work by Aghion and Tirole (1994) uses an incomplete contracting lens to examine trade-offs for the ownership and control of innovative activities. Hellmann (2002) provides the first explicit model of strategic venture investing. The key idea is that unlike private independent VCs who only seek financial gains, CVCs (or other strategic investors) have additional goals of reaping strategic benefits that arise from synergies with their core activities. In the model an entrepreneur can choose among independent VCs and CVCs, who compete on valuation and on the value-adding support provided to the entrepreneur. The entrepreneur's choice depends on the nature of the synergies. If the start-up develops a technology that is complementary to the CVC's core assets, then the CVC is chosen because it has stronger incentives than an independent VC to provide supportive effort. If, on the contrary, the entrepreneur's technology is a substitute that decreases the value of the CVCs core assets, there is a trade-off. The CVC might be willing to offer a higher valuation, but the independent VC will always provide more value-adding support. If the new technology is mildly harmful to the $\mathrm{CVC}$, the entrepreneur chooses the independent $\mathrm{VC}$, but if it is very harmful, independent VC and CVCs will syndicate the deal. The paper identifies a key distinction between alternative strategic motives. With complementary technologies, CVCs have competitive advantages over independent VCs, but with substitutes there is a conflict of interest for CVCs, where financial and strategic motives point in different directions. 
Norbäck and Persson (2009) also consider the trade-off between competition and cooperation between an incumbent corporation and a potential entrant. In their model the incumbent may finance the venture in order to preempt the entrepreneur from taking independent VC funding and overinvesting in the venture. Riyanto and Schwienbacher (2006) develop a model where the degree of complementarity increases with CVC financing. de Bettignies and Chemla (2008) take a different perspective, focusing on how a CVC program may help a corporation to attract and retain high quality managers.

Fulghieri and Sevilir (2009a) add product market competition into a theory of CVC. They consider an R\&D (or patent) race model where incumbents can choose between internal development versus supporting external development through CVC investments. Internal development has the advantage of capturing a higher share of the innovation profits, but external development provides stronger incentives to the entrepreneurs. A key insight from their analysis is that product market competition affects the optimal development strategy. In particular, CVC becomes more attractive when R\&D competition is more intensive, and where development speed is more critical. For external developments, they also consider a trade-off between CVCs, who pursue strategic interests, and independent VCs who provide more valuable support. ${ }^{22}$

Gompers and Lerner (2000a) document some stylized facts of CVC for the 1980s and early 1990s. They find that CVC is highly cyclical, and that CVC-backed companies are just as successful as VC-backed companies, at least when CVCs have a clear strategic focus. They find that CVCs pay higher valuations for companies, but only when the investments are outside their technological focus. Da Gbadji et al. (2011) provide a more recent overview of corporate venturing programs.

\footnotetext{
${ }^{22}$ Naturally there is a much larger theoretical literature that examines the relationship between start-ups and incumbents without focusing on CVC. See, for example, Anton and Yao (1994, 1995), Bharat and Galetovic (2000), Gans and Stern (2000), Mathews (2006) and Robinson and Stuart (2007).
} 
For the empirical analysis of CVC investments there are three main sampling frames: some papers use samples of acquisitions, some use IPO samples, and some use VC investment samples. The first two approaches allow access to rich information from IPO or acquisition records, but are particularly vulnerable to survivorship biases.

Masulis and Nahata (2011) use a sample of 2,589 acquisitions by US acquirers and identify companies backed by independent VCs or CVCs. Using event study methodology they find that acquisitions of corporate CVC-backed targets involve higher acquirer announcement returns than for independent VC-backed (or non-VC-backed) targets. This is consistent with CVCs being less focused on maximizing financial returns. Benson and Ziedonis (2010) also use event study methodology to analyze acquisitions of CVC-backed startups, but from a different angle. They focus on companies that were acquired between 1987 and 2003 by US corporations that have CVC programs, and examine the hypothesis that corporations use CVC to identify promising acquisition targets. The average CARs on acquisitions that had received CVC from their acquirer is $-0.97 \%$, and remains negative across several multivariate specifications. ${ }^{23}$ Interestingly, these same acquirers earn on average positive announcement returns of $0.67 \%$ on their other targets that did not received investments from their own CVC, suggesting that these companies are not inferior acquirers. The result also cannot be explained by the CVC parents being overconfident, suffering from poor governance, or being unsuccessful eliciting higher bids from competitors ("owner's curse"). However, they note that the negative announcement returns are earned by those corporations who organize their CVC investments internally, whereas corporations who organize their CVC investments through a more autonomous dedicated fund

\footnotetext{
${ }^{23} \mathrm{CAR}$ is the cumulative abnormal return on a certain stock, where 'abnormal' means in excess to a market model, and cumulative to the fact that the return is computed over a certain period.
} 
structure do not earn negative returns. This last finding suggests the importance of how CVC efforts are organized within corporations.

The second sampling approach is to use IPO data. Masulis and Nahata (2009) test the model of Hellmann (2002) using data on 177 CVC-backed companies that went public in the US between 1996 and 2001. They use IPO prospectuses to obtain information on the technological relatedness between start-up and CVC parent, the CVC's strategic objectives, and a variety of deal characteristics. They also use the CorpTech database for detailed industry classifications and product descriptions that go beyond the information contained in SIC codes. Their analysis controls for deal, investors, and start-up characteristics, and also controls for the endogeneity of CVC investments using a Heckman procedure. They find that start-ups receive funding from both complementary and competitive CVC investors, but that the two types of investments are quite different. CVCs obtain a larger share of board seats when there are technological complementarities. When the start-up is a potential competitor, CVCs are less likely to be lead investors in early stage deals, and they pay higher valuations, all of which is consistent with Hellmann (2002). One intriguing finding is that $45 \%$ of the start-ups in the sample obtain financing from CVCs whose parents have a competitive technology, suggesting that financial constraints or the benefit of obtaining certification from reputed incumbents brings entrepreneurs to accept financing from CVCs that may have conflicts of interest. In related work, Ivanov and Xie (2010) study a sample of 123 CVC-backed IPOs that took place in the US between 1981 and 2000. They find that CVCs obtain higher valuations at the IPO, and higher acquisitions premia. However, these results apply only if there is technological complementary between the entrepreneurial company and the CVC parent. Ivanov and Masulis (2011) further compare the governance of newly public companies that have a CVC (or strategic alliance) to those that are 
backed by independent VCs (and have no strategic alliances). They find that CVC-backed companies have more independent directors, stronger anti-takeover provisions, and fewer CEO replacements. They also have a lower probability of delisting or being acquired.

The third sampling approach is based on identifying CVC-backed companies in a crosssection of VC-backed companies, using the ThomsonOne database. Chemmanur et al. (2011b) identify 926 US CVCs, and retrieve additional information about their parents from Compustat, CorpTech, and Dun \& Bradstreet. They find that CVCs invest in companies that are younger and at earlier stages than those funded by independent VCs, and that they operate in less mature and more R\&D intensive industries. This is consistent with predictions of Fulghieri and Sevilir (2009a). CVCs also invest larger sums at higher valuation, and are more tolerant of failure. When bringing companies public, $\mathrm{CVC}$ attract underwriters and analysts with higher quality, and larger holdings by institutional investors. Conditional on going public, CVC-backed companies produce almost 50\% more patents in the next four years, and their stocks outperform those of companies backed by independent VCs. They also find that companies with a strong strategic fit with their CVC produce more patents, both before and after the IPO.

A different sampling approach is adopted by Kang and Nanda (2011), the only attempt so far to estimate both the strategic and financial returns to CVCs. They focus on the pharmaceutical industry and use the Recap database of Deloitte, a consultancy. This yields 71 pharmaceutical companies that were CVC-backed in 1985-2005. They find that financial and strategic returns are complementary. Park and Steensma (2011) use survey data and find that CVCs benefit companies with complementary assets.

CVCs have also attracted attention from management scholars. See Dushnitsky and Lenox (2005) and Maula and Murray (2001) among others. One issue that has been dealt with in 
management but not finance is that of compensation to top managers of CVCs. Dushnitsky and Shapira (2010) use ThomsonOne data for the 1990s coupled with a proprietary survey of compensation practices of UK investors. They document that CVCs which adopt performance pay have investment practices close to those of independent VCs, and fund-level performance which is even higher. However, the majority of CVCs do not have incentive pay, invest in safer, later stage deals, and have lower performance.

Overall, we find that the literature identifies some important differences between CVCs playing a complementary or competing role. CVCs appear to be able to provide portfolio companies with valuable inputs, and these benefits translate into good operating and stock performance. However, these benefits apply mostly to entrepreneurial companies that develop technologies complementary to those of the CVC's parent incumbent. In the case of competing technologies, entrepreneurs protect themselves mostly by diluting CVCs' control rights. What remains unclear is to what extent CVCs benefit their parent company, either financially or strategically. $^{24}$

\subsubsection{Bank-owned venture capital firms}

While CVCs have attracted considerable research attention, there is much less work on bank-owned VCs (BVCs henceforth). This is somewhat surprising given the substantial on-going role played by banks in the VC markets.

One of the challenges researching CVCs is that the distinction between substitutes and complements is always problematic. With banks, however, there is no such challenge, since there

\footnotetext{
${ }^{24}$ CVCs have also attracted much attention from management scholars. See Dushnitsky and Lenox (2005) and Maula and Murray (2001) among others. One issue that has been dealt with in management but not finance is that of compensation to top managers of CVCs. Dushnitsky and Shapira (2010) use ThomsonOne data for the 1990s coupled with a proprietary survey of compensation practices of UK investors. They document that CVCs which adopt performance pay have investment practices close to those of independent VCs, and fund-level performance which is even higher. On the contrary, the majority of CVCs that do not have incentive pay invest in safer, later stage deals, and have lower performance.
} 
is no competition between portfolio companies and BVCs. Hellmann et al. (2008) use

ThomsonOne to identify all deals made by BVCs in the US in 1980-2000, and compare them with deals done by independent VCs. BVCs invest in later stage deals that are financed by larger syndicates. They invest more in companies that operate in industries with higher debt and leverage levels. Matching these data with loan-level data from the Loan Pricing Corporation, they build a sample of potential bank-company pairs and find that banks are more likely to lend to a company if there is a prior relationship from an investment through their BVCs arm. These findings support the view that BVCs make investment decisions that are congruent with the strategic objectives of their owners. Companies seem to earn some benefit from this relationship, as evidenced by the fact that they obtain better rates on these loans. Put differently, there is no evidence that banks exploit their relationship by capturing information rents due to their prior information about the borrower.

Outside the US, banks seem to play an even larger role in the VC market, although it remains unclear how effective banks are promulgating VC markets. Becker and Hellmann (2005) show how German banks tried to develop the German VC market, making every conceivable mistake along the way. Mayer et al. (2005) compares the investments of different types of VC firms in four non-US countries (Germany, Israel, Japan and UK) and finds, among other things, that BVCs have a marked preference for later-stage investments, especially in comparison to CVCs.

\subsubsection{Government-sponsored venture capital firms}

A significant portion of $\mathrm{VC}$ firms obtain some funding from governments. Here we survey literature that looks at the impact of government policy from programs that directly 
support VC investing. In section 6.3 we consider the research on the impact of other government policies on VC markets.

There is considerable variety in how governments support VC firms, such as tax credits to $\mathrm{VC}$ firms, matching funds that augment private capital commitments, and direct government ownership of VC funds. The extent to which governments actually influence the investment decisions of these VC funds is often unclear and is likely to vary across different programs. It is likely that government-supported VC firms (GVCs henceforth) are under some pressure to consider not only financial returns, but also other policy objectives, such as investing in the local economy, creating jobs, and supporting the development of national or regional technological hubs, sometimes with a specific sector focus (see chapters 3 and 4 in Lerner et al. (2008)). There is a large number of reports, assessments, and white papers that deal with specific programs. Recent examples include Avnimelech et al. (2004), Cowling et al. (2010), and Maula and Murray (2003). Duruflé (2010) and Lerner et al. (2008) provide a broader cross-country overview.

An important step in understanding the economic impact of government-owned VC is to assess the performance of companies funded by government VC. Brander et al. (2011) compare the performance of companies backed by GVCs versus other types of VCs from 25 countries that were financed between 2000 and 2008. They find stark differences between companies that are only financed by GVCs, versus those that obtain funding also from other VCs. Companies with mixed independent VC and GVC funding raise more money than companies backed only by not government-sponsored VCs, while those backed purely by a GVC raise significantly less. Companies with mixed backing have higher exit rates than companies backed only by not government-sponsored VCs, and this effect can be largely explained with the higher investment amounts. Companies backed purely by a GVC have significantly lower exits rates, even after 
accounting for their lower investment amounts. In related work, Brander et al. (2010a) find a somewhat similar pattern for the number of patents created by companies. Overall these results suggest that on their own, GVCs are associated with weaker performing companies, but when investing alongside with other VCs, this no longer applies. Brander et al. (2010a) also distinguish between different types of government support, and find that GVCs that are only partially controlled by the government perform better than those that are fully owned by the government.

At an aggregate level, there is also a question whether government and private $\mathrm{VC}$ financing complement or substitute each other. Leleux and Surlemont (2003) use a panel of European VC and find that investments by government VCs predict subsequent increases in the investments of private VCs. Making bold econometric assumptions, Cumming and MacIntosh (2006) argue that the Canadian government's supply of funds actually reduces the total supply of VC. Brander et al. (2010b) also look at Canadian data and find some limited and indirect evidence of crowding out, although only for low technology sectors. Finally, Brander et al. (2011) use a panel approach of looking at the amount of private and government VC investment across countries and industries. They find a strongly positively contemporaneous correlation of GVC and VC investment amounts by non government-sponsored VCs. Prior GVC amounts also tend to increase future non government-sponsored VC amounts, although the effects are not always significant. Their results provide some support for the complements hypothesis, and no support for crowding out effects.

Overall, these comparisons of private versus government $\mathrm{VC}$ reveal a variety of patterns, implying that simplistic judgments about GVCs being either better or worse than private VCs are inappropriate. More research is needed before we can draw any firm conclusions. 


\subsubsection{The internal organization of venture capital firms}

The internal organization of VC firms is relatively underexplored. Sahlman (1990) provides some preliminary discussion, while Gompers (1994) and Hsu and Kenney (2005) provide a historical perspective on the evolution of partnerships as the dominant structure for $\mathrm{VC}$ firms. In this subsection we look at a few studies that focus the internal organization of VC firms more directly.

Alter (2009) develops a model of VC firms' size and hierarchical structure. Partners aggregate into firms to facilitate the training of junior professionals and to allow efficient use of their time. Senior partners provide the knowledge necessary to screen and monitor companies. Junior partners provide the labor, provided senior partners spend unobservable effort in training them. Economies of scale in training junior partners lead to larger firm size (measured by the number of partners). But since mentoring is unobservable, training is a public good and there are limits to growth. The model predicts that more experienced partners form larger firms, that the ratio of senior to junior partners should be stable, and that $\mathrm{VC}$ firm size increases with the amount of deals in the industries it specializes in. These predictions are consistent with evidence from a detailed, hand-collected database of $158 \mathrm{VC}$ firms located in California and active between 1982 and 2002.

Several papers examine the importance of the human capital of VC firms. Dimov and Shephard (2005) investigate the relationship between education and experience of VC firms' partners, and find that some aspects of human capital contribute to some but not all dimensions of performance. Zarutskie (2010) finds that partners' prior VC experience or start-up experience correlates with performance (measured by higher successful exit rates), that prior industry also 
correlate with better performance to a lesser extent, but that having an MBA correlates negatively with performance. ${ }^{25}$

Rather than looking at such correlations, Bottazzi et al. (2008) attempt to identify the channels through which VC partners' human capital may affect performance. They find that VCs with prior business experience (entrepreneurial, managerial or consulting) are more active investors, providing more support with tasks such as recruiting management or raising additional funds. After controlling for both selection effects and for the endogeneity of being active, they find that support activities lead to better performance. Bottazzi et al. (2008) also look at the allocation of tasks within firm. They find that partners with prior business experience, and partners with longer VC experience are more likely to be put in charge of looking after portfolio companies. Moreover, looking at the within-firm variation, they find that the most active partners are those with the longest VC experience.

A related issue is the specialization of VC firms and individual partners. Gompers et al. (2009) test theories of capital allocation within internal capital markets using data from VC partnerships. They use VentureSource to build a sample of 3,518 venture partners active in 822 VCs between 1975 and 2003, and measure success as yearly rate of IPO or acquisition of portfolio companies. They find that VC firms that specialize in just a few industries perform better than generalist VCs. Performance is weakest when the partners in a generalist VC firm are also generalists.

Overall these results suggest that experience and specialization of individual partners is an important determinant of how VC firms invest and perform. However, relatively little is known about the inner working of VC funds. We are not aware of any studies about the selection

\footnotetext{
${ }^{25}$ Somewhat related, Cumming et al. (2005b) examine how VC firm characteristics, such as different types of expertise, affect the firms fundraising, in terms of capital commitments and drawdowns.
} 
process by which individuals join or found $\mathrm{VC}$ firms, the compensation and promotion of individuals within $\mathrm{VC}$ firms, or the process by which investment decisions get made within $\mathrm{VC}$ firms.

\subsection{Venture capital firms' investment strategies}

In this section we examine research on the investment strategies of VC funds, looking first at investment scope and then at cross-border investing. We consider the choice to syndicate deals separately in section 4.3.

\subsubsection{Portfolio size and scope}

How VCs manage their portfolios affects their strategic positioning and ultimately their returns. Several theory consider the fact that VCs manage more than a single investment, looking at interactions among investments, and examining the $\mathrm{VC}$ firms investment portfolio strategies. Kanniainen and Keuschnigg (2004) first examine VC portfolio interactions, noting that the optimal portfolio size depends on the marginal return of VC advice. Fulghieri and Sevilir (2009b) further develop this idea, noting that when the VC partners' human capital is limited there is a trade-off. A larger portfolio allows reallocating human capital across start-ups, which is valuable when the probability that a start-up fails is high. A smaller portfolio, instead, provides stronger incentive to provide support to companies. ${ }^{26}$ Moreover they argue that a smaller portfolio limits the VC's ability to extract rents ex-post. They show that the benefits of larger portfolios increase with the portfolio's focus. Therefore VCs choose larger portfolios when startups have lower potential value, higher risk, and are technologically more related. The paper also predicts that VCs should sometimes divest some companies in order to focus their scarce human capital to those which show higher upside potential.

\footnotetext{
${ }^{26}$ This is in the spirit of prior work by Bernile et al. (2007) who also model VC portfolio choices, focusing on the dilution of incentives that comes from adding more companies.
} 
Inderst et al. (2007) take a complementary approach. They hold portfolio size constant and focus on the benefits of having 'shallow pockets' to induce higher entrepreneurial effort. In their model all start-ups are ex-ante equal. Competition among portfolio companies for a VC's limited funds provides entrepreneurs with stronger incentives. This strategy has value when investments are staged, so that start-ups need to come back to the VC for refinancing. At first sight, staging might dilute entrepreneurial incentives by increasing VCs' ability to extract rents when refinancing. However, this "bargaining power effect" is countervailed by a "competition effect" that arises from the need to outperform other start-ups in the portfolio in order to secure re-financing.

Hochberg and Westerfield (2010) develop a model that focuses on the payoff heterogeneity among ideas (or new technologies). They show that the size and focus of the portfolio are substitutes, because investor ability to add value to projects is limited. A more focused portfolio allows VCs to increase the payoffs of a given new technology, but it limits diversification across technologies. A wider portfolio increases the returns to investment, since the VC can choose which projects to continue from a wider pool of technologies. Consequently, optimal portfolios will be larger and less focused when a VC has more skilled partners (or other sources of competitive advantage, like reputation), and when there is less competition.

Overall, we would say that while there are some interesting theoretical ideas about the structure of VC portfolios, surprisingly little is known about what the relevant factors are, and how they modify our understanding of VC investment decisions about individual portfolio companies. It seems clear that further progress would come from careful empirical work in this area. One promising step in this direction is Sørensen (2008) who empirically examines portfolio-level interactions. He finds evidence that when VCs make investment decisions, they 
not only draw on their experience from prior investments, they also consider the option value of future learning.

\subsubsection{Cross-border investments}

One interesting aspect of the investment strategies of VC firms is the extent to which VCs choose to invest across national border. Investing abroad has a cost in terms of distance, dealing with a foreign institutional environment, higher uncertainty about the business environment etc. At the same time, investing abroad VCs can widen the set of potential investments, in the hope of finding more promising start-ups. This part of the literature has been entirely empirical so far.

Using country level data, Aizenman and Kendall (2008) look at the globalization of the VC industry, focusing in particular on cross-border investment. They find that geographic distance, common language and colonial ties all predict higher trade flows between countries. The US is by far the largest exporter of investments, while China is the largest importer. Crossborder deals are commonplace outside the US, whereas the majority of deals within the US remain domestic. Countries that attract foreign VC investments tend to have high level of human capital, better business environments, high military expenditures and deeper financial markets. Schertler and Tykvová (2010) also look at cross-border fund flows and find that higher stock market returns but lower stock market capitalization favor VC inflows.

At the individual deal level, Bottazzi et al. (2011) find that trust also has a strong effect on cross-border investments, as discussed in section 3.1. In section 3.2 we also discussed how VC contracts and investment amounts depend on the quality of legal enforcement -see in particular Lerner and Schoar (2005), Kaplan et al. (2007), Bottazzi et al. (2009) and Balcarcel et al. (2010). 
Another strand of literature considers the effect of cross-border investments on the performance of start-ups. Chemmanur et al. (2010), and Hazarika et al. (2009) both use large samples drawn from ThomsonOne, both find that companies financed by foreign VCs tend to outperform others. Chemmanur et al. (2010) focus on the role of syndication. They find that the distance of the international VCs is negatively correlated with success, but that the presence of a local syndication partner is positively correlated with success, thus mitigating the negative distance effect. Hazarika et al. (2009) focus instead on the effect of institutional and cultural factors on start-up success. They find that syndicates of foreign and local VCs are associated with start-up success, and argue that cultural differences create incentives for better ex-ante screening and due diligence, so VCs invest in start-ups from high cultural distance only when they perceive substantial upside potential. Dai et al. (2009) also develop a similar analysis.

Overall we would say that the globalization of VC and the role of cross-border investments remain under-researched. While the recent work has shed some light on how crossborder investments can help to bridge different VC environments, we still lack a clear understanding of how and why the countries differ in the first place, in terms of the structure of their VC industries. The challenge for researching this is that there are relatively few data points, and many possible explanations. Studies of how the VC grew in individual countries can be illuminating in terms of their institutional details, but rarely offer easily generalizable insights. Further progress is most likely to be made from the study of globally representative and comparable samples at the individual deal level.

\subsection{Relationships among venture capital firms}

VC compete with each other, but they also cooperate with each other, mostly notably through the process of syndication. A number of papers examine this syndication process. Some 
papers use the syndication data to make inferences about $\mathrm{VC}$ networks and reputations. And some papers focus directly on how VC firms build and possibly lose their reputation.

\subsubsection{Syndication of venture capital deals}

Brander et al. (2002) were the first to examine the relationship between syndication and performance. They formalize a theory where the first investor in a start-up may benefit from second opinions, improving selection - and also the refinancing decision at the next stage of investment. They model this as a sequential sampling problem, and obtain a model prediction that syndicated deals are less profitable, because VCs do not need a second opinion on the best deals. They also consider that VCs may have complementary skills, so that value adding and support activities may benefit from the participation of more investors, which predicts that syndicated deals are more profitable. They test the relative importance of the two hypotheses with Canadian data from the 1990s, finding that syndicated deals have higher returns, which supports the value-adding hypothesis.

Several papers further develop the theory. Casamatta and Haritchabalet (2007) note that while syndication can improve the screening process, it also requires the original VC to show a potentially lucrative deal to another $\mathrm{VC}$, who could become a potential competitor for the deal. They show that having both screening skills and an ability to add value are necessary for syndication to occur in equilibrium. Cestone et al. (2006) use an asymmetric information set-up to examine how VCs would choose their syndication partners. They show that syndicating with more able VCs might not optimal, so that in equilibrium only high quality VC firms want to syndicate with other high quality players. Tykvová (2007) examines how hold-up and moral hazard among investors limit the extent that syndication occurs in equilibrium. Bachman and 
Schindele (2006) argue that syndication is a device to deter VC expropriation of entrepreneurial ideas by increasing the reputation loss among syndicate members.

Tian (2011) empirically considers the relationship between syndication and performance using US data and finds that syndicated deals perform better on a variety of measures. They are more likely to have an exit, achieve higher IPO valuations, and are less underpriced at IPO. Das et al. (2011) also use US data from ThomsonOne and look at the exit rates of deals with different syndication structures, controlling for endogeneity with a standard two step procedure. They find a complementary role of the selection and value adding explanations for syndications. Building on Brander et al. (2002), Chemmanur and Tian (2010) also assume that different VCs contribute different value-adding expertise. In their model this is observable to other VCs but not to entrepreneurs. Complex projects will then be financed by syndicates, and VCs will tend to work with the same networks over time. They provide evidence consistent with the theory.

Lerner (1994b) provides some initial exploration of syndication patterns, and shows that top-tier firms have a preference to syndicate with each other, especially in early round deals. Du (2011) examines the importance of syndicate homogeneity more generally. She finds that VCs have a strong preference of homophily in terms of homogenous syndicates. She then identifies a trade-off between the short-term and long term benefits of forming heterogeneous syndicates. She finds that heterogeneous syndicates have lower successful exit rates, even after controlling for endogenous selection effects. However, there appears to be a long-term benefit, as witnessed by a higher survival rate for $\mathrm{VC}$ firms that participate in heterogeneous syndicates.

Somewhat at odds with this previous literature, Hochberg et al. (2011a) find relatively little evidence of homophily, especially with respect to experience. They argue that syndication formation is partly driven by a trading logic where some partners provide capital and other 
access to deals. In a somewhat related vein, In a somewhat related vein, Bubna et al. (2011) examine the clustering in VC partner choices. They find that VCs tend to syndicate with preferred partners drawn from clusters that they call VC "communities." Using flexible community detection algorithms originating in the physical sciences, they examine the number of communities, their composition, and their effect on performance. They find that VCs communities are structurally complex, with heterogeneity in some characteristics such as size and influence but homogeneity in characteristics in other dimensions such as stage focus. Firms funded by community VCs are more likely to experience a successful exit.

\subsubsection{Social networks among venture capital firms}

Recently financial economists discovered 'networks', a concept that sociologists have studied for decades. Several of these sociology papers already measured networks in the context of venture capital syndicates. Sorenson and Stuart (2001), using ThomsonOne data, argue that networks among VCs contribute to diffusing information about potential investments across geographic and sector boundaries, so that VCs with pivotal network positions manage to invest in more distant companies. Sorenson and Stuart (2008) further probe the origins of network ties, identifying circumstances under which VC firms syndicate with other firms that are at a distance in their network.

Hochberg et al. (2007) are the first to use the standard sociological measures of network positions to examine the relationship between syndication-based networks and performance, measured both at the deal and the VC firm level. Using a sample of 3,469 funds managed by 1,974 US-based VCs from ThomsonOne, they find that VC firms with greater network centrality experience economically significant higher IPO and acquisition rates for their portfolio 
companies. They obtain similar results at the individual deal level, and explore some of the origins of network positions.

Hochberg et al. (2010a) use the same sample to study whether syndication is used by incumbent VCs as a barrier to entry against new outsider VCs. They find that local VC markets experience less entry when incumbents are more intensely networked. Outsiders enter a local market largely by establishing ties to incumbents, inviting them to syndicate on their turf. When this happens, other incumbents tend to react strategically by reducing their syndications with incumbents that allowed entry. Finally, incumbents who enjoy high network centrality appear to benefit from entry deterrence by paying lower valuations for their deals. Hochberg et al. (2011b) further explore the competitive structure of the VC industry and estimate a structural model of VC investments. Their results are consistent with the presence of network effects.

\subsubsection{Venture capital firm reputation}

It is widely believed that reputation is paramount to financial intermediaries, and that this applies to commercial and investment banks, brokers and VCs alike. Much of the literature discussed in this survey implicitly or explicitly assumes that reputation is a valuable asset to VCs. To give two examples, Hsu (2004) explains his valuation differences in terms of reputational differences among VCs, and Gompers (1996) explains grandstanding in terms of young VCs desire to build a reputation and track record. Nahata (2008) explicitly examines the relationship between reputation and investment performance, not surprisingly finding a positive relationship. A less obvious finding concerns the measurement of reputation, namely that the most powerful measure of reputation consists of calculating a VC's market share of the IPO capitalization value. He argues that this measure captures both screening and value-adding abilities. 
Reputation can be gained, but it can also be lost. Two recent papers consider the potential loss of reputation from being sued. Atanasov et al. (2011) use a sample of lawsuits from Westlaw's database that took place between 1975 and 2007 where the defendant is a VC firm. Most of the cases involve entrepreneurs claiming some form of expropriation by the VC. Somewhat reassuringly, they find that more reputable VCs are less likely to be sued. Their main results concern the reputational consequences of being sued. They find that $\mathrm{VC}$ firms that experience lawsuits raise less capital than a sample of matched VCs, they invest in fewer and less successful deals, and they also find fewer syndication partners in their subsequent deals. Tian et al. (2011) look at a different set of lawsuits, namely accounting fraud in VC-backed companies that recently went public. They find that VC firms whose portfolio companies were subjected to lawsuits face greater difficulty, e.g., in raising additional funds.

To preserve their reputation with their LP, VC firms typically deploy their funds in the sectors that they said they would invest in. Cumming et al. (2009), note that some firm deviate from their original investment plan, something he calls "style drift". They show that style drift is less common among young funds, and is associated with better performance. Presumably VC firms only risk their reputation with LPs when they expect to be reaping significantly higher returns from a change in investment strategy.

Overall we note that the introduction of network concepts into the finance literature is belated and welcome. However, one cannot help but notice an important shortcoming of both the recent finance literature, as well as the prior sociology literature. At this stage the literature has not yet provided convincing solutions to the fundamental endogeneity problems. Are networks causing superior performance or are they caused by superior performance? And are networks measuring the importance of social relationship among firms, or are they merely correlated with 
unobservable fundamentals such as firm quality. A similar observation can be made about the literature on $\mathrm{VC}$ reputation.

\subsection{The relationship between General and Limited Partners}

Central to the relationship between VC firms and their LPs is the partnership agreement that governs their contractual relationship. Sahlman (1990) provides a useful overview, and Litvak (2009a; 2009b) provides some detailed discussion from a legal scholar's perspective. In this section we discuss the research that tries to explain the structure of these agreements.

Gompers and Lerner (1996) were the first to empirically examine VC partnership contracts. They look at a sample of 140 agreements and document substantial heterogeneity in contractual covenants. They argue that this variation is not only determined by agency considerations, but that cyclical fluctuations in demand and supply affect relative bargaining power which in turn affect the use of covenants.

Gompers and Lerner (1999b) examine 419 US venture partnerships raised largely in the 1980s and find that younger VCs obtain lower carried interest and higher management fees, so that their compensation is less sensitive to performance. More experienced VCs have a larger carried interest, resulting in greater performance sensitivity. They also find that compensation is not related to a proxy for fund performance, namely the VC's stakes in their portfolio companies that went public as a fraction of the fund size.

Lerner and Schoar (2004) develop a theory that fund managers can use the illiquidity of venture funds to screen for 'deep-pocket' LPs that will not renege on their capital commitments. If current investors know more about the quality of the VCs, they can hold up these VCs. In their model, LPs may harm VCs when they are hit by liquidity shocks that prevent them from re- 
investing in the VC's next fund, thus increasing the VC's cost of funds. ${ }^{27}$ Using a sample of 243 US venture partnerships, they find that transfer restrictions are more common in 'first time' funds, where information asymmetries are more acute, and in funds investing in industries with longer investment cycles (e.g., pharmaceuticals) that make liquidity shocks more likely.

Chung et al. (2010) develop a learning model that implies that future fundraising creates incentives for private equity funds to generate high returns over and above those provided by fees. When investors use past performance to decide both about re-investing and about the size of their future commitment, past performance has an incentive effect beyond what embodied in fees. The incentive effects of fundraising should be highest for first time funds, where information on partners' abilities is minimal. These results are tested with a sample of 838 US partnerships that manage over 1,700 funds. These estimates indicate that fundraising incentives are about as large as fee incentives, and stronger for buyout funds that are more scalable than venture funds.

Kandel et al. (2011) develop a theory model of VC investing that highlights a refinancing inefficiency that arises from the fixed maturity of venture fund. Good projects that require more time to become profitable may be terminated because the opportunity cost of the VCs' monitoring capital is too high. And bad projects may be refinanced if the market is unable to distinguish them from good ones that have yet to mature.

Metrick and Yasuda (2010) obtain data on 238 funds (of which 94 venture) from one large LP. Their data contains substantial information of the revenues to the GPs, including a detailed break of the carried interest and various fees. They use an option pricing framework to model the VC funds expected revenues. The model predicts that small variations in contract

\footnotetext{
${ }^{27}$ As discussed in section 5.3, Hochberg et al. (2010b) argue that there are additional ways for LPs to hold-up VC firms.
} 
terms should lead to large differences in expected revenue. They also examine how the various revenue measures vary with fund characteristics and past performance. They find that VC funds are less scalable than buyout funds, that their expected revenues depend less on management fees, and that past performance increases funds size, although less so for $\mathrm{VC}$ funds than for buyout funds.

Finally, Robinson and Sensoy (2011b) examine a sample of 295 VC funds (and 532 buyout funds) that extends from 1984 to 2010 and that allows for a rich characterization of compensation structures. A major advance of this paper is that it can match detailed compensation data with detailed performance data (based on quarterly cash flows), as well as with fund ownership data (capital commitments). They find a strong cyclical component of compensation: since fund size increases during fundraising booms while management fees and carried interest remain stable in percentage terms, the fixed component of compensation also increases. Another important result is that net returns are not correlated to compensation, nor to the managerial ownership of the funds. This result holds even after including a proxy for risk and controlling for market condition. It suggests that compensation structures adjust to market conditions. Higher ability VCs generate higher gross returns, charge higher fees and raise larger funds, and thus end up delivering the same net returns to LP.

Overall, we notice that data availability has restricted the amount of research into the contracts between LPs and VCs, leaving ample room for future work. Contractual and reputational issues are still largely to be explored, as is the matching between LPs and GPs.

\section{Section 5: Returns to venture capital investments}

Computing the financial returns to $\mathrm{VC}$ investments is of obvious importance, but turns out to be a challenging task. Most of the advances in this line of research are fairly recent, and much 
remains to be done. In this section we examine data and methodological challenges, we review the main results obtained so far, and we briefly compare VC returns to the returns to buyouts. ${ }^{28}$

\subsection{Data and methodological challenges}

Computing financial returns requires good data and a solid methodology widely shared by researchers. In the case of $\mathrm{VC}$, both these ingredients are scarce. Only recently has there been progress in obtaining reliable estimates. Most of these research challenges are not unique to VC, but apply to research on alternative asset (most notably buyouts) more broadly. Yet VC returns also pose some additional challenges due to the way VC firms obtain capital from their LPs, invest it, and return it back to LPs.

\subsubsection{Gross versus net returns}

To understand the returns literature it is important to distinguish between "gross returns" and "net returns". Gross returns are the returns earned by a VC fund from investing in portfolio companies. The cash outflows consist of the amounts invested in portfolio companies, and the inflows are the amounts received (in cash or publicly listed stock) at the time of exiting the company. These returns are called "gross return" because they measure the entire return generated by the VC investment, but do not account for any compensation (fees and carried interest) taken by the VC firm that is managing the investment. Calculating gross returns requires round level investment data (including valuations).

"Net returns" are the returns earned by LPs that invest into VC funds. The cash outflows are the so-called 'capital contributions' that LPs make when investing in a VC fund. The inflows

\footnotetext{
${ }^{28}$ The returns we are dealing with here are those generated by a professional asset management activity. They differ from the returns to private equity analyzed by Moskovitz and Vissing-Jorgenson (2002), where private equity is defined extremely broadly, including private equity held by founders, employees, private investors (such as family, friends or angel investors), institutional investors (such as VCs) and others. They find that despite a higher risk, the returns to private equity are lower than the returns to public equity, and suggest that private benefits and entrepreneurial optimism may explain this.
} 
are the distributions (cash or stock) made by the VCs out of the VC fund, after the exit of their portfolio companies. These returns are called "net return" because they measure the returns actually received by the LPs, net of all management and performance fees. Calculating net returns requires data at the fund level.

Net and gross returns also differ in terms of their timing, reflecting when the cash flows actually occur. For instance, capital contributions (the LPs' outflows) happen prior to VC fund investments (the VCs' outflows), and distributions (the LPs' inflows) happen after the actual exit (the VCs' inflows). ${ }^{29}$

Measures of gross and net returns are clearly related, but they lend themselves to answering different questions. Gross returns focus on the performance of the underlying companies. They are appropriate for comparing performance across industries, geographies, investment stages and other fine-grained company characteristics. Net returns focus on the performance of funds, and are appropriate for examining the performance of different VC firms that may have different expertise, different organizational structures or different portfolio investment strategies. Moreover, we can think of gross returns as a measure of the abilities of VC firms to generate returns, whereas net returns reflect the LPs capabilities of picking successful VC fund managers.

\subsubsection{Data availability and reporting biases}

We already discussed the main data providers in Section 2. Here we elaborate on some issues that are specific to the computation of returns. Obtaining data for computing returns turns out to be a difficult task. VC firms are not required by regulations to disclose their investments,

\footnotetext{
${ }^{29}$ Moreover, note that in the case of IPOs, the relevant exit date for calculating gross returns may not actually be the IPO date itself, but rather when the VCs lock-up period expires (or even the day the stock is distributed to the LPs). Stock prices at these two points in time can differ substantially.
} 
distributions or returns, and most LPs are not, either. ${ }^{30}$ As a consequence there are no comprehensive databases for valuation and returns data. The main data sources are those VCs or LPs who voluntarily provide information, either to the commercial data providers, or directly to researchers. LPs and VCs may thus choose whether to report, and if so, what data to report.

The main problem is reporting bias, i.e., that fact that reporting is likely to be (positively) correlated with performance. Phalippou and Gottschalg (2009) find that funds that do not report cash flow data in ThomsonOne have a success rate in terms of IPO or acquisitions of portfolio companies that is five percentage points lower than for funds that report such data. ${ }^{31}$ Because one cannot obtain data from non-reporting VCs or LPs, nor guarantee full disclosure by the reporting ones, it is difficult to quantify biases and make comparisons across databases. These problems affects all return databases, whether they use data self-reported by VCs, such as CEPRES, data from LPs, like Preqin, or from both, like ThomsonOne and VentureSource.

The ideal solution to the biased reporting problem would be to obtain the universe of cash flows that occur between LPs, VCs, and portfolio companies. While this has proven impossible so far, some inroads have been made. Ljungqvist and Richardson (2003) obtain comprehensive data from one large LP that invested in buyout and venture funds. Robinson and Sensoy (2011a) also obtain data from a large LP data that extend back to 1984 and up to 2010, considerably extending the time period one can study. These datasets, that have data at fund level, avoid one important selection bias, namely selective reporting within an LP portfolio, but the question remains how representative these LPs are within the universe of LPs. Lerner et al. (2007) show

\footnotetext{
${ }^{30}$ Only recently US and UK pension funds are required to provide detailed investment information under the Freedom of Information Acts of the respective countries. Preqin, a commercial provider, obtain data on this basis and offers a database of LP returns that has yet to be exploited in academic research.

${ }^{31}$ This result supports the common practice of using the rate of IPOs and acquisitions as proxies for returns.
} 
that performance varies widely across LPs, even among large ones. It seems unlikely that LPs with very poor returns would want to make available their entire data.

For round level data, Sand Hill Econometrics provides company valuation data. They augment data on US VC investments from VentureSource with a variety of proprietary sources to compute round-level valuations and returns. An interesting feature of round-level data is that they allow one to study risk and returns as a function of individual investment (company) characteristics, providing a complementary angle to that of fund data. They also allow more information on the timing of write-offs, which are rather frequent event in $\mathrm{VC}$ and are not captured well in fund-level data. Missing data and measurement error, on the other hand, complicate the calculation of round-based returns.

Publicly listed private equity funds provide another source of data that is free of deliberate reporting biases (Jegadeesh et al., 2010). While there are several publicly listed fundsof-funds that invest in VC (and other private equity funds), most of the LPs money still flows into VC funds directly. The main concern is that listed funds-of-funds do not hold portfolios of VC funds that are representative for the industry at large. Still, as more funds get listed and longer time series become available, further research may be able to address some of these concerns.

Summing up, returns may be measured at the company round level, at the level of the VC fund, and even at the level of the LP portfolio. At each level, data have to deal with some selfselection issues, and are suitable for addressing different questions. Most research to date has been done at the fund level. 


\subsubsection{What measure of returns?}

The three most common return measures are the Internal Rate of Return (IRR), Cash-on-cash multiples, and the Public Market Equivalent (PME). None of these measures correct for risk, an issue we consider in the next subsection. The IRR is the standard measure used by practitioners and industry associations, and is also common in academic studies. It is defined as the discount rate which makes the Net Present Value (NPV) of a stream of cash flows equal to zero. Cash-oncash multiples compute how many times the invested capital has been multiplied when it is returned. They do not take into account the investment duration and are more popular among practitioners than academics.

Kaplan and Schoar (2005) introduce the public market equivalent (PME) as a return measure for private equity (or alternative) investments. It compares a VC investment with an investment of the same amount in a public market (such as the S\&P500 or Nasdaq Composite indices) over the same time period. The PME is defined as the ratio of the return value to the VC investments over the return value of the public market investment. A ratio higher than one means the venture investment has returned a higher amount than a corresponding investment in the public market. The PME allows a simple comparison of returns that avoids the weaknesses of the IRR. One important issue with the PME is that it implicitly discounts cash flows with the public market rate of return. This implicitly assumes that investments are liquid and that betas equal to one, both of which appear to be inconsistent with the evidence for VC.

The IRR is a standard tool for corporate finance decision, but several shortcomings make its use in VC problematic. ${ }^{32}$ First, the IRR assumes that dividends can be reinvested at the IRR itself. If the IRR is very high (low), then, it overstates (understates) the effective rate of

\footnotetext{
${ }^{32}$ Well-known shortcomings of the IRR are discussed in corporate finance textbooks. They included the possibility of multiple solutions, computational difficulty, sensitivity to cash flow timing and project scale.
} 
return. This is a common situation in VC, where the dispersion of returns is substantial (see below). Second, the IRR overstates the variability of the true rate of return. Third, the IRR of aggregated and disaggregated cash flows differ, so that the average IRR of two venture funds differs from the IRR of the aggregated investments made by those two funds. When performance is negatively related to the duration of venture investments, as it turns out to be the case in venture investments, averaging IRRs computed over different time horizons is incorrect. ${ }^{33}$ In realistic examples the average IRR can easily be two or three times the IRR of the aggregate underlying cash flows.

One solution to these problems would be to use Net Present Values (NPV) for comparing performances, but in the case of $\mathrm{VC}$ it is particularly difficult to agree on what discount rate to use, and on what valuation to apply to companies prior to exit. Moreover, NPV is scale dependent, preventing direct comparisons across funds and investments. Phalippou (2008) discusses one possible solution to this, using a so-called modified IRR that employs a discount rate derived from the fund's cash flows.

One interesting observation is that the choice of performance measure itself may affect incentives, especially for timing investment and exit decisions. For example, the IRR measure provides an incentive to exit investments soon, even at the cost of forcing an outcome whose rate of return is lower. The negative effects of these incentives are relevant for portfolio companies, investors, and society as a whole.

\subsection{Return estimates}

We now turn to the main results in the literature on VC returns. There appears to agreement among researchers that $\mathrm{VC}$ returns are not as high as those reported by industry participants and

\footnotetext{
${ }^{33}$ The duration of a venture capital investment is the difference between the weighted average payment time and the weighted average capital contribution time, where weights equal to the present value of each payment.
} 
associations (Phalippou, 2011) compares the way returns are computed by industry associations and by academics). Beyond that, however, there is also a lively debate about what the true returns might be. Most of the literature focuses on net returns, so we will start there.

\subsubsection{Net returns}

The seminal paper of Kaplan and Schoar (2005) examines 577 venture funds raised between 1980 and 2001 from the ThomsonOne database. They report an average (median) IRR of 17\% $(13 \%)$ for $\mathrm{VC}$ investments. They then focus on the PME and find that on a value-weighted basis, the average PME is found to be 1.21, and the median is 0.92 . These net returns are not particularly high, given that they do not control for either systematic nor liquidity risk. The dispersion of returns is substantial, with a standard deviation of 0.74 for the PME and 0.31 for the IRR: there is substantial performance heterogeneity across funds, with a wide distance between high and low achievers.

Phalippou and Gottschalg (2009) find results that are broadly consistent with Kaplan and Schoar (2005), but also provide a different methodological perspective. They use ThomsonOne data for 708 venture funds raised between 1980 and 1993. Beyond the inclusion of non-US funds, their main difference with Kaplan and Schoar (2005) is that they apply three corrections to computing returns. First, they more closely examine 'mature' funds (over ten years old) that show no cash flows for two years or more, and report a constant net asset value (NAV) over the same period. Using a sample of 476 such mature funds they find them to be poor performers that do not get liquidated to avoid acknowledging poor performance. Phalippou and Gottschalg (2009) make an assumption to write off their NAV. This alone generates a $7 \%$ reduction in average PME returns. Notice that this is the opposite of what is assumed by Kaplan and Schoar (2005), who take reported NAV values as correct; more evidence is needed to validate either 
approach or point to an appropriate middle ground. ${ }^{34}$ Second, Phalippou and Gottschalg (2009) weight returns using as weight the net present value of actual investments instead of the total committed capital; this takes into account that committed capital is drawn down over several years. This further reduces returns by $2 \%$. Third, they augment the sample with data on funds that have no cash flows but exit outcomes (IPOs, acquisitions, defaults), and extrapolate the performance of this funds. This further reduces returns by $4 \%$. These three corrections bring the PME of venture investments below unity. While each of these three corrections is up for debate, both studies document relatively modest (risk un-adjusted) returns to venture investing, and a substantial variation in returns across funds.

A number of other papers also find results broadly consistent with these findings. Jones and Rhodes-Kropf (2004), also using the ThomsonOne cash flow database and the same sampling filters as Kaplan and Schoar (2005), find an average IRR of 19.3\%, with a standard deviation of 59\%. Ljungqvist and Richardson (2003) look at a sample of VC and (predominantly) buyout funds invested by a single LP between 1981 and 1993, and find an IRR of $19.8 \%$ for all funds ( $14.1 \%$ for venture and $21.8 \%$ for buyout), compared to a return of $14.1 \%$ for the S\&P500.

More recently, Robinson and Sensoy (2011a) use a database that includes data up to 2010 and apply the same methodology of Kaplan and Schoar (2005). They find a lower performance of liquidated VC funds: the average (median) IRR -is 9\% (2\%); the average (median) PME is 1.03 (0.82). Using also non-liquidated fund, or employing the Nasdaq index to compute PMEs, barely changes these figures. Dispersion of returns also remains substantial, with a standard deviation of 0.47 for IRR and 0.95 for PME . An interesting finding is that the PME is found to

\footnotetext{
${ }^{34}$ Driessen et al. (2011) provide evidence that the NAV of funds that are over ten years old are higher than zero (as assumed by Phalippou and Gottschalg, 2009), but also lower than their reported value (as assumed by Kaplan and Schoar, 2005).
} 
depend on beta, but not linearly as one would expect. Rather, the PME is relatively insensitive to changes around beta values estimated in prior work.

Overall we note that while different studies obtain somewhat different estimates of the net returns, there is an emerging consensus that average returns of $\mathrm{VC}$ funds do not exceed market returns. ${ }^{35}$ Moreover, there is considerable dispersion and skew. While the net returns of the best VC funds are clearly very high, the median VC fund rarely beats the market, and the lower tail of the distribution can generate large negative returns. What is even more concerning is that these estimates of returns do not account for systematic risk and lack of liquidity, a topic we turn to now.

\subsubsection{Risk and illiquidity}

The previous section discusses the finding for VC net returns, but these returns do not account for systematic risk. Moreover, as mentioned above, the PME measure implicitly assumes a beta of one. The estimation of systematic risk in VC investments poses further methodological challenges. VC investments are (largely) non-traded assets whose value is only observed sporadically. To estimate the risk of net returns researchers rely on extremely sparse data, where the inflows (distributions) may occur over a decade after the initial outflows (capital contributions).

Many studies acknowledge the problem of accounting for risk and provide some indirect controls. Kaplan and Schoar (2005) find that including controls for average market risk and for fund stage/industry focus characteristic does not materially change their results. Phalippou and Gottschalg (2009) control for risk by using industry/size-matched cost of capital and show that this decreases PMEs even further. Ljungqvist and Richardson (2003) develop a model that takes

\footnotetext{
${ }^{35}$ Other recent papers that use fund-level data include Cumming and Walz (2010) and Krohmer et al.(2009).
} 
into account information about a fund's portfolio diversification to compute realized risk. They assign betas to portfolio companies using their Fama-French industries, and obtain average portfolio betas using weights equal to the capital disbursement to each portfolio company. They estimate an average beta of 1.12 for VC funds. Jones and Rhodes-Kropf (2004) integrate the principal-agent relation between $\mathrm{LP}$ and $\mathrm{VC}$ into the derivation of the return required by the $\mathrm{VC}$ when investing in a specific company. The resulting (second best) contract does not fully diversify risk, so that idiosyncratic risk needs to be priced, and influences returns. Moreover, they estimate a beta of 1.80 .

More recently, Driessen et al. (2011) provide an alternative approach to measuring the systematic risk of private equity funds that avoids assuming a specific distribution of returns. ${ }^{36}$ This addresses the problem that standard distributions do not seem to fit well private equity returns, which exhibit many liquidations (clustered at zero) and several moderate to very high returns (a relatively fat right tail). Their approach also avoids the need to observe a time series of market returns for private equity investments. To achieve this, however, they need to assume a parametric cross-sectional structure for alphas and betas. The resulting methodology is based on the idea that a levered position on S\&P500 can mimic the same cash flow patterns of a private equity fund, and reach value zero at the time the fund is liquidated. This is achieved by choosing an appropriate degree of leverage, and therefore an appropriate beta. Estimation is then obtained using moment conditions in a Generalized Method of Moments framework. They report a beta of 2.7 for VC funds.

In addition to being risky, $\mathrm{VC}$ is also an illiquid form of investment. While LPs are usually large diversified investors, they may face liquidity pressure, like in the aftermath of the "dot.com bubble," or in the 2007 financial crisis. Robinson and Sensoy (2011a) examine the

\footnotetext{
${ }^{36}$ See also Woodward (2009) on measuring risk.
} 
liquidity properties of VC funds. They note that LP outflows (capital contributions) and LP inflows (distributions) are both pro-cyclical, and that the net inflows are also pro-cyclical. This means that VC fund provide liquidity when public market valuations are high, but become liquidity sinks when valuations are low. This became a particular problem in the 2007 crisis where especially larger funds made high unexpected capital calls at a time that LPs were struggling to maintain liquidity.

Overall we would say that these are still early days in terms of understanding and measuring the risk and liquidity properties of $\mathrm{VC}$ funds, let alone the heterogeneity among different types of VC firms in this respect. A methodology commonly shared by researchers still has to emerge, and several methodological issues need to be overcome.

\subsubsection{Persistence of returns and size effects}

One important issue in VC is whether success is due to 'skill or luck.' Other asset management industries do not show much persistence of returns at the level of the intermediary. Kaplan and Schoar (2005) find considerable persistence across VC funds: fund managers that outperform with one fund tend to outperform also with their subsequent fund. The effect is economically large, as one percentage point of higher performance in a fund is associated with almost two thirds of a percentage point of higher performance in the subsequent fund. This is puzzling, as competition should wipe out any differences in (net of fees) returns.

Whereas Kaplan and Schoar (2005) use the realized returns of funds still active at the time of fundraising (which is an 'ex post' measure), Phalippou (2010) uses the returns to a VC's liquidated funds, and the returns to active funds computed at the time of raising a new fund (an 'ex-ante' measure). Phalippou (2010) then finds that performance persistence is weaker and applies mainly for funds with below median returns, i.e., it is the poor performing funds that 
predictably repeat their performance. His results are consistent with Lerner et al. (2007)

(discussed in the next sub-section) suggesting that low performing LPs persist in funding poorly performing funds. Robinson and Sensoy (2011a), using more comprehensive data and the same methodology as Kaplan and Schoar (2005), also find somewhat weak evidence of persistence.

A related issue is to what extent fund characteristics are correlated with returns. Two fund characteristics stand out from the analysis: fund sequence number (i.e., whether a fund is the first, second, third, etc. raised by a VC) and size. Kaplan and Schoar (2005) find that returns (IRRs) are higher for higher sequence funds, and that size has a concave relationship with performance. They also find returns fall after increases in fundraising and entry (measured five years earlier), a result consistent with the cyclical pattern of both returns and fundraising and with the findings of Gompers and Lerner (2000b) on the cyclicality of valuations at company level. Phalippou and Gottschalg (2009), using the PME as performance measure, find broadly similar results, except for the concavity of the size/performance relationship (possibly due to sample differences). They also note that the relationship between higher sequence funds and performance is driven by underperformance of first time funds, i.e., funds that are raised by the first time by a VC partnership. Moreover, they find that performance is not related to higher sequence numbers.

Robinson and Sensoy (2011a) extend these results (using PME) to more recent years. They find a concave size/performance relationship, but do not find an effect of sequence number. They also find a negative relationship between fund inflows at fundraising and subsequent fund performance, but only for larger funds. Finally, Driessen et al. (2011) find that fund-level alpha is not related to size, but that beta increases with size. They argue that the higher return of large funds is due to higher risk exposure rather than higher abnormal performance. 
Overall we would argue that the evidence does suggest some return persistence, and a concave relationship between size and performance. These results contrast with the evidence on mutual funds, where there is no persistence, and there appears to be a convex size /performance relationship (Chevalier and Ellison, 1997). The reasons for such concave relationship have to be further explored; they may include voluntary restraint due to scarcity of highly profitable deals, limits to scalability at the venture firm level, and constraints in the fundraising process.

The persistence result raises the question of why better VC firms cannot extract the value of superior performance potential through higher fees. Hochberg et al. (2010b) rationalize this result in a model where incumbent LPs can hold up VCs by threatening not to reinvest in their next fund, which would deter investment by other LPs; as a consequence VCs compensate incumbent LPs with low fees. Marquez et al. (2010) explain persistence in a theoretical model by considering assortative matching between VCs and companies when past returns are difficult to verify at the time of fundraising.

\subsubsection{Differences in Limited Partners returns}

Most VC return studies used fund-level data, but a few recent contributions look into returns earned by LPs from the whole portfolio of venture and buyout funds they invest in. Lerner et al. (2007) build a dataset of 838 funds raised in the 1990s and invested by 352 LPs. For 341 funds they manage to compute IRRs. ${ }^{37}$ They document large differences in average weighted returns across LP types that go beyond differences risk attitudes or in objectives. Endowments earn higher returns, even after controlling for fund type and vintage year, LP type, proximity to the fund, and private equity experience. This advantage is mostly due to investments in better

\footnotetext{
${ }^{37}$ Their main source to identify funds is Galante's Venture Capital and Private Equity Directory, published by Asset Alternatives, a consultancy, and build IRRs using the 2004 Private Equity Performance Monitor, published by Private Equity Intelligence, another consultancy. They also use personal connections to LPs to obtain investment records.
} 
venture funds. Banks are the worst performers. The endowments' superior performance can be partly explained by better reinvestment decisions. In particular, better LPs seem to be better at gathering and processing soft information. This advantage also shows in superior performance when investing in 'first time' funds, a result that also assuages concerns that endowments mainly benefit from preferential access to the funds of older VCs. These results raise deeper questions on why some LPs appear to be consistently more successful. Lerner et al. (2007) conjecture three possible explanations. One is differences in organizational structure that may lead to different degrees of autonomy of the investment committees that select funds. Another is human resources practices, like compensation and promotion systems, that may provide different incentives towards maximizing returns. Finally, some LPs may prize building relationships to GPs or other objectives more than maximizing returns. Further research with more detailed data on LP characteristics will be required to disentangle these conjectures.

Hochberg and Rauh (2011) focus on the possibility of home bias in LPs' allocations. They use a dataset compiled from ThomsonOne, VentureSource, Preqin and Capital IQ that includes investments by 631 LPs in 3,554 funds (of which about 1,000 are VC funds) over the period 1980-2009. Their central finding is that while all LP categories exhibit home bias, only public pension funds perform significantly worse on their in-state investments - on average 5.5\% per year. In fact, public pension funds perform worse on their in-state investments than out-ofstate LPs investing in their state. This contrasts with previously documented over-performance of public pension funds on in-state listed stocks, pointing to the different nature of private equity investments. Hochberg and Rauh also find that underperformance is higher in more corrupt states, suggesting that political pressure may be an important determinant of the home bias for investments in unlisted equity. 
Dyck and Pomorski (2011) focus on a specific LP type, and analyze the role of size for investor performance. They use a sample of defined benefit pension plans from a variety of countries, covering the years from 1990 to 2008 and US\$6 trillion assets, from a Canadian consultancy. They find that plans in the top quintile enjoy almost 50 basis points of higher performance compared to the average sized plan. These gains arise from more intense use of internal management across asset classes, but to a larger extent from higher returns (and larger investments) in asset classes where experience, skills, access to privileged co-investments, and negotiating power are likely to be important, notably private equity and real estate. They document a $6 \%$ net of fees yearly abnormal return in private equity when moving from the $1^{\text {st }}$ to the $5^{\text {th }}$ size quintile. Like those documented by Hochberg and Rauh (2011), these are economically large effects that point to the importance of further understanding how money is channeled to GPs.

Da Rin and Phalippou (2011) collect information on over 150 LPs worldwide and find that the size of the allocation to private equity is the main factor that explains how LPs select, contract and monitor private equity funds. Size turns out to be a more important determinant of investment styles than characteristics like investor type, experience or location. Controlling for such characteristics, LPs with larger private equity allocation also obtain more favorable terms from the funds they invest in. They also document that these practices are associated with higher returns, pointing to a tangible effect of the size of LPs' allocations to private equity.

Overall, these recent studies document intriguing differences in LP behavior and performance; they are only starting to open the black box of how investments in $\mathrm{VC}$ is ultimately sourced and deployed and to shed light on the economics of value creation in these investments. 


\subsubsection{Gross returns}

While most papers focus on net returns, as small number of papers examine the structure of gross returns. These studies have to deal not only with the problem that valuations occur infrequently, and often remain unreported, they also encounter an interesting conceptual survivorship problem. Company valuations are only observed when a company raises funds. Yet a company has a greater incentive (and more possibilities) to raise funds when its valuation has increased. For any round-to-round calculation observed returns are therefore likely to be biased upwards relative to true returns. Estimation of gross returns with round level data therefore typically requires an appropriate econometric approach for dealing with this survivorship bias.

Gompers and Lerner (1997) measure returns for a single private equity group from 19721997 and find an average yearly three-factor alpha of 8\%. Cochrane (2005) develops a maximum likelihood approach to correct for survivorship bias that extrapolates the value of investments that have no recorded subsequent deal. He estimates betas under the assumption of log-normality of returns. ${ }^{38} \mathrm{He}$ employs Sand Hill Econometrics round-level data to compute returns to individual (company-level) venture investments. The estimated (annualized) alpha of selectionbias-corrected investments is $32 \%$. Cochrane estimates beta to be close to 2 . Notice that such a round-level beta reflects the systematic risk of individual investments, not of the VC fund as a whole. There is some debate whether the high alpha is realistic, whether high fees can explain the marked differences between gross and net returns, and to what extent measurement and specification issues also affect these estimates.

Korteweg and Sørensen (2010) develop a Bayesian methodology to deal with dynamic survivorship bias, i.e. the above mentioned issue that the timing of observed cash flows is

\footnotetext{
${ }^{38}$ Ewens (2010) questions this assumption, noting that round level returns have fat tails. He suggests modeling gross return with an asymmetric three-state mixture distribution, and argues that such an approach uncovers some of the unique risk attributes of $\mathrm{VC}$ investments.
} 
endogenous to the underlying assets' valuation. They consider a dynamic extension of the Heckman selection model, with dynamic filtering and smoothing, and then use a Markov Chain Monte Carlo estimator (using Gibbs sampling) to produce the posterior distribution of valuations. Like in Cochrane (2005), the use of a selection equation requires making assumptions on the distribution of returns. They employ a more recent (and more complete) version of the Sand Hill Econometric data and find an alpha of about $30 \%$. Their estimate of beta is 2.8 .

Gross return calculations naturally take the perspective of the VC. An interesting related question concerns the returns to the founders of VC-backed companies. Hall and Woodward (2010) use the Sand Hill Econometrics database to estimate the entrepreneur's returns. Three out of four venture-backed entrepreneurs have no returns at all, but the successful ones receive on average $\$ 5.8$ million at exit. Making several assumptions about the entrepreneurs and their degree of risk-aversion, they argue that the expected utility of being a venture-backed entrepreneur is surprisingly low.

Overall we note that while the net returns to $\mathrm{VC}$ appear to be low relative to market returns, this cannot be said for the estimates of gross returns. One possible explanation for the high alphas relates to data limitations. Both papers extrapolate returns for missing data, with almost half of all rounds missing valuation data. Another possible explanation is that the difference between high gross returns and low net returns is a real phenomenon. This would point to possible inefficiencies in the relationship between LPs and VCs, where some LPs paid too much fees to VCs firms (especially poor performing ones, as discussed in the previous subsection). 


\subsubsection{Comparison to other private equity investment returns}

To conclude, we briefly compare net returns to $\mathrm{VC}$ to those obtained by investing in the other main type of private equity investment: buyouts. A number of studies compute both $\mathrm{VC}$ and buyout returns, so a sensible comparison is possible. The earlier studies typically found that VC outperforms buyouts. Kaplan and Schoar (2005) find that buyout investments have lower returns than VC, with an average (median) PME of 0.83 (0.93), and a standard deviation of 0.65 . Jones and Rhodes-Kropf (2004) find a higher IRR for venture funds than for buyout funds (19\% versus 9\%). They also find considerable heterogeneity in buyout returns. Ljungqvist and Richardson (2003) instead find an average IRR of $14.1 \%$ for venture and of $21.8 \%$ for buyouts. Phalippou and Gottschalg (2009) find that VC funds have lower PME than buyouts (0.88 vs. 0.96). Moreover, Robinson and Sensoy (2011a) also find that VC fund perform worse than buyout funds (average PMEs are 1.03 versus 1.18, median PMEs are 0.82 versus 1.09). The difference in findings between the studies can be largely explained by the choice of sample periods, especially the inclusion of VCs funds that lost considerable money in the aftermath of the “dot.com bubble."

Different studies also find widely different estimates for beta. Jones and Rhodes-Kropf (2004) estimates a beta of 1.8 for VC funds versus 0.6 for buyout funds. Ljungqvist and Richardson (2003) only find mild differences (1.12 versus 1.08), yet Driessen et al. (2011) find a much larger difference, estimating a beta 2.7 for $\mathrm{VC}$ funds, compared to around 1.3 for buyout funds.

Section 6: Venture capital and the economy

In this section we examine how VC is affected by, and contributes to the economy at large. Section 6.1 looks at how VC-backed companies contribute to the economy in terms of 
generating innovation. Section 6.2 looks at the role of $\mathrm{VC}$ in employment, growth, and entry.

Section 6.3 looks at the geography of VC. Section 6.4 examines the role of government in the VC industry.

\subsection{The contribution of venture-backed companies to innovation}

VC investments typically focus on high technology and high growth sectors of the economy, such as information technology, life sciences, and more recently 'clean' energy technologies. Kortum and Lerner (2000) provide a systematic assessment of the claim that VC promotes innovation, examining the relationship between $\mathrm{VC}$ financing and patenting. They look at a panel of US manufacturing industries, and find that $\mathrm{VC}$ funding is associated with sectors that have higher contemporaneous patent production. The effect of $\mathrm{VC}$ on patenting is larger than the effect of corporate R\&D funding. They address endogeneity by using a regulatory change in 1979 for the funding of VC firm, the relaxation of the so-called 'prudent man rule' that allowed pension fund to invest in $\mathrm{VC}$ funds. The interaction of this one-time regulatory change with the industry's pre-1979 level of VC funding is also used, because different industries can be differentially affected by the regulatory change. Kortum and Lerner (2000) also consider a variety of ways of instrumenting for $\mathrm{R} \& \mathrm{D}$. Their main results survive all these endogeneity tests. $^{39}$

Hirukawa and Ueda (2008a) confirm these results in a longer time series. They then look at growth in total factor productivity (TFP) as an alternative measure of innovation. They find no significant relationship between VC and an industry's TFP growth, although they find a positive relationship between VC and labor productivity. Whereas Kortum and Lerner (2000) and Hirukawa and Ueda (2008a) only look at contemporaneous effects , Hirukawa and Ueda (2008b)

\footnotetext{
${ }^{39}$ Popov and Roosenboom (2009) find similar results in a cross-country study of European countries, though they cannot rely on a clean instrumental variable.
} 
use a panel autoregressive model to examine which way Granger-causality runs: from VC to innovation ("VC first" hypothesis) or from innovation to VC ("Innovation first" hypothesis). They find no evidence for either hypothesis in the patents data. Somewhat surprisingly, however, the TFP data provides some evidence for both hypotheses: Lagged first round VC investments predict TFP growth (later rounds do not) and lagged TFP growth predicts VC investments. These papers highlight the difficulties of identifying the relationship between $\mathrm{VC}$ and innovation at the industry level, where intertemporal relationships are difficult to identify. ${ }^{40}$

Several papers attempt to identify a relationship between $\mathrm{VC}$ and innovation at the individual company level, where it is easier to account for the timing of $\mathrm{VC}$ and innovation (in section 3, we also discuss some related evidence). Hellmann and Puri (2000) use a handcollected sample of Silicon Valley companies, some of which obtain VC. They show that companies pursuing innovator rather than imitator strategies, are more likely the obtain VC. Using a duration model, they then establish that VC-backed companies are faster to bring their product to market. Moreover, this effect is more significant for innovator companies, where time to market is likely to be of greater strategic importance. ${ }^{41}$ Puri and Zarutskie (2011) find VCs disproportionately fund companies with no initial revenues but who subsequently demonstrate stronger growth. Chemmanur et al. (2011a) use US census data to examine the relationship between VC and TFP growth. They find that companies financed by VC already have higher TFP growth in the years prior to obtaining VC. In addition, they find that obtaining VC is associated with continued higher TFP growth. The effect is mostly associated with early VC

\footnotetext{
${ }^{40}$ Cockburn and MacGarvie (2009) also consider an "Innovation first" hypothesis, but focus on the specific issue of 'patent thickets'. They argue that patent thickets discourage entry and additional investments by start-up companies. Looking at the software industry, they find that VCs delay their investments in submarkets with deeper patent thickets.

${ }^{41}$ Gans et al. (2002) use a survey-based sample of 55 VC-backed companies matched with non-VC-backed companies and find that VCs are associated with stronger cooperation with established firms in the commercialization phase. Colombo et al. (2006) obtain similar results in a survey-based sample of over 500 Italian high-tech start-ups.
} 
rounds, and is largely driven by higher sales. Companies backed by high reputation VCs also achieve faster TFP growth. Company-level data therefore provides stronger support for the importance of VC than the industry-level data.

Using a database of German start-ups, Engel and Keilbach (2007) find that having more patent applications increases a company's chance of obtaining VC. They find no systematic difference in patent applications after the receipt of VC, although they find that VC-backed companies experience faster employment growth. Looking at within VC samples, Mann and Sager (2007) find that companies that have more patents obtain more investments. Hsu and Ziedonis (2011) find that VC-backed companies with more patents obtain higher valuations, especially in earlier rounds. Finally, Tian and Wang (2011) develop a measure for a VCs tolerance of failure, based on the time it takes to shut down failing companies. They show that companies backed by failure-tolerant VCs are more innovative. They note that younger and less experienced VCs tend to be less failure tolerant than more established VCs.

Lindsey (2008) examines the relationship between VC financing and the formation of strategic alliances, including cooperative R\&D agreements. Using a sequenced conditional logit approach, she shows that companies that have a common $\mathrm{VC}$ investor are more likely to form strategic alliances. Moreover, such alliance formation is associated with better exit performance. In a related contribution, Hsu (2006) compares VC-backed companies to companies that obtained US federal research grants (specifically Phase 2 SBIR grants) and find that obtaining VC is associated with a substantial boost in alliance activity. Ozmel et al. (2007) consider a twoway interaction between alliances and VC. They find that obtaining VC is followed by higher alliance activity, but also note that forming alliances leads to less subsequent $\mathrm{VC}$ financing. 
Lerner et al. (2003) also observe pattern of substitution between alliances and VC, where alliance activity increases in times when $\mathrm{VC}$ becomes less abundant.

Overall we believe that the body of empirical evidence is consistent with the notion that VCs select more innovative companies, and then help them with the commercialization process. The results suggest that $\mathrm{VC}$ plays a greater role for commercialization (as measured by bringing products to market, and forging strategic alliances) than for the generation of further innovation (as measured by patents and TFP). The different papers take a variety of approaches for disentangling selection and treatment effects, typically finding evidence for both. This is consistent with the view that selection effects are partly due to the expectation of treatment (discussed in section 2). Several of these papers also look at the relationship between innovation and the likelihood of good exit (IPO or acquisition), invariably finding a positive correlation.

\subsection{The role of venture capital for entry, employment and growth}

Closely related to the question of how VC impacts innovation are questions of how it impacts other measures of economic value creation, such as entry, employment, and company growth. Samila and Sorenson (2011) use panel data on US Metropolitan Statistical Areas (MSAs) to examine the relationship between VC financing on the one hand, and the number of start-ups, aggregate employment and aggregate income on the other. They find a positive relationship across a variety of model specifications, including an instrumental variable specification that uses the returns of local college and university endowments as an instrument for the supply of VC.

Mollica and Zingales (2007) adopt a similar approach, instrumenting the supply of VC with the state's pension fund size. They also find that increases in VC investments lead to increases in new business creation, as well as increases in patents. Popov and Roosenboom 
(2008) use a panel of industries across several European countries and focus on a difference-ofdifference approach. They find that higher levels of $\mathrm{VC}$ investment are associated with more entry, especially in high-R\&D (and also high-entry) industries. All of these aggregate-level studies suggest a positive correlation between $\mathrm{VC}$, entry and employments.

Company-level studies typically confirm this positive relationship between VC and measures of economic growth. Puri and Zarutskie (2011), using US Census data, find that only $0.11 \%$ of new companies created over a 25 year sample period from 1981-2005 are funded by VC, yet these companies account for $4 \%$ to $5.5 \%$ of employment. They show that VC-backed companies grow faster at every stage of the investment cycle, i.e., both before and after the receipt of VC. Chemmanur et al. (2011a) find a positive effect of VC on company productivity. Davila et al. (2003) and Engel and Keilbach (2007) also find a positive effect of VC on employment. ${ }^{42}$

Overall the literature consistently finds a positive relationship between $\mathrm{VC}$ funding and other measures of economic value creation. While the literature seems to identify social value creation, there remains an open question on the social costs of VC. In section 5 we noted that the private returns to $\mathrm{VC}$ are often disappointing, implying that $\mathrm{VC}$ investments have significant opportunity cost. In addition it should be noted that the $\mathrm{VC}$ industry has benefitted from a variety of government support measures that we discuss in section 6.3. Performing a social cost benefit analysis therefore remains an important challenge in the literature.

\subsection{Public policy for venture capital}

Economists have suggested several possible rationales for a role of government in VC. There may be market failures for the financing of early-stage companies, due to a variety of

\footnotetext{
${ }^{42}$ Note also that these results contrast with the findings for the buyout side of the private equity, where the effect on employment is a matter of great debate and concern (Davis et al. 2008).
} 
informational problems. Innovation may have external effects not captured by the individual investing in it. Establishing a viable VC industry may require institutional change that is difficult to coordinate in private markets. Lerner $(1998 ; 1999)$ provides an overview of these arguments, and Lerner (2008) provides an extensive discussion with many relevant examples. In section 4 we survey studies of government-owned VCs. Here we focus on public policy for the promotion of the VC industry.

Gompers and Lerner (1998b) use US data at the state level to examine how a variety of government policies affect VC fundraising. They emphasize the effect of two public policies. First, they show that the regulation of public pension funds, and especially the relaxation of the prudent man rule in 1979, had a dramatic effect on the supply of VC. Second, they find a negative and significant relationship between the capital gains rate and venture fundraising. They argue that this effect is unlikely to come from the supply of $\mathrm{VC}$ as many pension funds are tax exempt. It is more likely to come from the demand side, where higher capital gains are likely to dampen entrepreneurial activity. This argument builds on the work of Poterba (1989a; 1989b) who uses an occupational choice model to show how capital gains affect the incentives to become an entrepreneur. It is also consistent with the theoretical work of Keuschnigg and Nielsen (2004) who show that, in a model with two-sided moral hazard, capital gains taxes have a detrimental effect on effort provision by both the entrepreneur and the VC.

There are econometric challenges in distinguishing between supply and demand factors, and eliminating other time-varying country-specific effects. Da Rin et al. (2006) argue that estimating ratios such as early-stage or high-tech $\mathrm{VC}$ over total VC eliminate at least some of these concerns (the reasoning is similar to the difference-in-differences approach of Rajan and Zingales (1998)). They use a country-sector panel of European VC investments and focus on the 
difference between marginal income tax rate and the marginal capital gains rate. They find that increases in this difference increase the early-stage and high-tech ratios, suggesting that lower capital gains benefit particularly early stage and high-tech VC investments.

Governments play a role in establishing and regulating stock markets. Black and Gilson (1998) discuss the importance of an active stock market for VC exits and the 'recycling' of VCs' scarce human capital. Michelacci and Suarez (2004) provide a formalization of their argument. Jeng and Wells (2000) examine a panel of aggregate VC investments in 21 countries and find some correlation between VC investments and the importance of stock markets, although the effect is less pronounced for early-stage than late-stage investing. By contrast, Da Rin et al. (2006) find that the creation of new stock markets in Europe increased the ratio of early to late stage VC. Finally, Cumming et al. (2006) provides evidence that IPOs are used more often than acquisitions in countries that score well on a variety of legal quality indices.

Another dimension of government policy concerns labor market rigidities. Jeng and Wells (2000) find that labor market rigidities are associated with less early-stage VC investing. Da Rin et al. (2006) also find that these rigidities reduce the ratio of high-tech VC investments. Bozkaya and Kerr (2011) distinguish between two types of labor regulation: protecting workers from layoffs versus insuring worker in case of layoff. They use a country-sector panel of European VC investments, and employ a difference-of-difference approach that distinguishes between high versus low volatility sectors. They show that while the overall level of employment protection has relatively little explanatory power, the distinction between labor protection and labor insurance does. Specifically, labor protection (insurance) is associated with lower (higher) VC investment in more volatile sectors. 
Governments provide considerable funding for R\&D, so the question arises how this affects the VC industry. Lerner (1999) looks at the US experience with the Small Business Innovation Research (SBIR) program. He examines the growth of 541 companies that received capital contributions from SBIR grants, and compares it against a matched sample of 894 nonawardees companies with similar characteristics. The main result is that program awardees outgrew the matched sample in both employment and sales terms. Moreover, awardees were more likely to receive $\mathrm{VC}$ funding, suggesting that the programs provides some certification to companies. Interestingly, these benefits were confined to companies in $\mathrm{VC}$ intensive regions, mostly California and Massachusetts, suggesting some limitations to the role played by SBICs. Gans and Stern (2003) also evaluate the SBIR program by looking at the performance of 100 companies that received funding in the 1990s, augmenting official data with information obtained through a survey, from the US Patent Office, and from VentureSource. They complement Lerner's results by showing that awardees performed better in industries that attract more private venture capital investment, and which are also characterized by higher appropriability. This suggests that public VCs can provide social benefits by focusing on the supply of funds to companies that are operate in low appropriability industry, which private VCs find unattractive.

Samila and Sorenson (2010) consider the effects of US federally funded research on regional innovation (measured through patenting rates) and entrepreneurship (measured through entry rates). Their methodology is similar to their 2011 paper discussed above. They find a complementarity between federal research funding and $\mathrm{VC}$, where higher levels of government research funding increase innovation and entrepreneurship only if there is a significant presence 
of local VC. By contrast, Da Rin et al. (2006) find no significant effects of government R\&D spending on their early-stage or high-tech ratios.

Overall we note that the research on the role of government policies remains sparse. The results of a complementarity between government R\&D spending and $\mathrm{VC}$ remind us of the importance of looking at the interactions among different government policies. We believe that the role of government in $\mathrm{VC}$ remains under-researched. There has been no systematic evaluation of the costs to government of supporting VC (e.g., what is the fiscal impact of reducing capital gains). There has also been little appreciation of the shape that government intervention should take (e.g., what is the best model of government-sponsored VC). Finally, the political economy dimension of regulation has also received no attention, despite the significant overhaul in government regulation in the aftermath of the financial crisis.

\section{Section 7: Conclusion}

Much progress has taken place in VC research. Yet, much remains to be done. Our view is that further advances are likely to come from creative augmentation of commercially available databases with other databases or survey data; from accessing proprietary databases; and from initiatives like the collection of systematic data such as the Kaufmann survey. Some of the areas where more research is needed are the early (pre-VC) history of VC-backed companies, and the choice between alternative sources of financing. Few papers so far shed light onto the internal working of VCs firms, how they make decision, how they attract, motivate, and retain talent, how they manage the relationship with LPs, how they compete, etc. Much of the work so far, both empirical and theoretical, has been on the VC-company relationship, and only recently have researchers delved into the details of the relationship between GPs and LPs. One might expect more research in that part of the literature. 
More broadly, little research has gone into the industrial organization of the VC industry and its evolution over time. The internationalization in money flowing to both VCs and companies, and the ensuing intensification of cross-border deals pose new economics questions that have yet to be answered. Finally, while there are a lot of public policy programs relating to VC, our understanding of these policies, and our ability as academics to make public policy recommendations remains limited. More and better data on public programs and policies are needed to provide more precise evaluation, and a proper cost/benefit analysis.

Finally we note that the global VC industry is a relatively young industry that is still undergoing major growing pains and significant structural changes. Researchers need to remember that they are chasing a moving target. We do not expect them to stand still in such a dynamic environment. 


\section{References}

Admati, A., Pfleiderer, P. (1994). "Robust financial contracting and the role of venture capitalists”. Journal of Finance 49, 371-402.

Aghion, P., Tirole, J. (1994). “The management of innovation”. Quarterly Journal of Economics $109,1185-1209$.

Aghion, P., Bolton P., Tirole J. (2004). "Exit options in corporate finance: liquidity versus incentives". Review of Finance 8, 327-353

Agrawal, A., Cooper, T. (2010). “Accounting scandals in IPO firms: do underwriters and VCs help?". Journal of Economics and Management Strategy, forthcoming.

Aizenman, J., Kendall, J. (2008). "The internationalization of venture capital and private equity”. Unpublished working paper.

Alter, A. (2009). “The organization of venture capital firms”. Unpublished working paper.

Amit, R., Brander, J., Zott, C. (1998). "Why do venture capital firms exist? Theory and Canadian evidence". Journal of Business Venturing 13, 441-66.

Amit, R. Glosten L., Muller E. (1990). “Entrepreneurial ability, venture investments, and risk sharing.” Management Science 36, 1232-45.

Anton, J., Yao, D. (1994). “Expropriation and inventions”. American Economic Review 84, 190209.

Anton, J., Yao, D. (1995). “Start-ups, spin-offs, and internal projects”. Journal of Law, Economics and Organization 11, 362-78. 
Atanasov, V., Ivanov, V., Litvak, K. (2011). "Does reputation limit opportunistic behavior in the VC industry? Evidence from litigation against VCs”. Journal of Finance, forthcoming.

Avnimelech, G., Kenney, M., Teubal, M. (2004). “Building venture capital industries: understanding the U.S. and Israeli experiences”. Berkeley Roundtable on the International Economy, UC Berkeley.

Bachmann, R., Schindele, I. (2006). “Theft and syndication in venture capital finance”. Unpublished working paper

Baker, M., Gompers, P. (1999). "Executive ownership and control in newly public firms: the role of venture capitalists". Unpublished working paper.

Baker, M., Gompers, P. (2003). "The determinants of board structure at the initial public offering". Journal of Law and Economics 46, 569-598.

Balcarcel, A., Hertzel, M., Lindsey, L. (2010). “Contracting frictions and cross-border capital flows: evidence from venture capital". Unpublished working paper.

Ball, E., Chiu, H., Smith, R. (2011). "Can VCs time the market? An analysis of exit choice for venture-backed firms". Review of Financial Studies 24, 3105-3138.

Baron, J., Burton, M., Hannan, M. (1996). “The road taken: origins and evolution of employment systems in emerging companies". Industrial and Corporate Change 5, 239-275.

Barry, C., Muscarella, C., Peavy, J., Vetsuypens, M. (1990). "The role of venture capital in the creation of public companies: evidence from the going public process". Journal of Financial Economics 27, 447-71. 
Bascha, A., Walz, U. (2001). "Convertible securities and optimal exit decisions in venture capital finance". Journal of Corporate Finance 7, 285-306.

Baum, J., Silverman, B. (2004). "Picking winners or building them? Alliances, patents, and human capital as selection criteria in venture financing of biotechnology startups". Journal of Business Venturing 19, 411-436.

Becker, R., Hellmann, T. (2005). "The genesis of venture capital: lessons from the German experience”. In: Keuschnigg, C., Kanniainen, V. (Eds), Venture Capital, Entrepreneurship, and Public Policy. MIT Press, Cambridge.

Bengtsson, O. (2011a). "Relational venture capital financing of serial founders". Journal of Financial Intermediation, forthcoming.

Bengtsson, O. (2011b). "Covenants in venture capital contracts”. Management Science, forthcoming.

Bengtsson, O., Bernhardt, D. (2011a). "Different problem, same solution: contract-specialization in venture capital". Unpublished working paper.

Bengtsson, O. ,Bernhardt, D. (2011b). "Lawyers in venture capital contracts: theory and evidence". Unpublished working paper.

Bengtsson, O., Hand, J. (2011). “CEO compensation in venture capital markets”. Journal of Business Venturing 26, 391-411.

Bengtsson, O., Hsu, D. (2010). "How do venture capital partners match with startup founders?" Unpublished working paper. 
Bengtsson, O., Ravid, A. (2011). "The geography of venture capital contracts". Unpublished working paper.

Bengtsson, O., Sensoy, B. (2011a). "Investor abilities and financial contracting: evidence from venture capital". Journal of Financial Intermediation, 20, 477-502

Bengtsson, O., Sensoy, B. (2011b). "Changing the nexus: the evolution and renegotiation of venture capital contracts". Unpublished working paper.

Benson, D., Ziedonis, R. (2010). "Corporate venture capital and the returns to acquiring portfolio companies”. Journal of Financial Economics 98, 478-499.

Ber, H., Yafeh, Y. (2005). “Can venture capital funds pick winners? Evidence from pre-IPO survival rates and post-IPO performance". Unpublished working paper.

Bergemann, D., Hege, U. (1998). "Venture capital financing, moral hazard, and learning". Journal of Banking and Finance 22, 703-35.

Bergemann, D., Hege, U. (2005). “The financing of innovation: learning and stopping”. RAND Journal of Economics 36, 719-752.

Bergemann, D., Hege, U., Peng, L. (2009). "Venture capital and sequential investments". Unpublished working paper.

Berger, A., Udell, G. (1998). “The economics of small business finance: the roles of private equity and debt markets in the financial growth cycle". Journal of Banking and Finance 22, 61373. 
Berger, A., Schaek, K. (2011). "Small and medium-sized enterprises, bank relationship strength, and the use of venture capital". Journal of Money, Credit and Banking 43, 461-90.

Berglöf, E. (1994). “A control theory of venture capital finance”. Journal of Law, Economics and Organization 10, 247-67.

Bernile, G., Cumming, D., Lyandres, E. (2007). “The size of venture capital and private equity fund portfolios". Journal of Corporate Finance 13, 564-590.

Bernstein, S., Lerner, J., Sørensen, M., Strömberg, P. (2010). "Private equity and industry performance". Unpublished working paper.

Bharat, A., Galetovic, A. (2000). "Weak property rights and holdup in R\&D”. Journal of Economics and Management Strategy 9, 615-642.

Bhidé, A. (1994). "The origin and evolution of new businesses". Oxford University Press, Oxford.

Bienz, C., Walz, U. (2010). "Venture capital exit rights". Journal of Economics and Management Strategy 19, 1071-1116.

Bienz, C., Hirsch, J. (2011). “The dynamics of venture capital contracts”. Review of Finance, forthcoming.

Black, B., Gilson, R. (1998). "Venture capital and the structure of capital markets: banks versus stock markets". Journal of Financial Economics 47, 243-277.

Bottazzi, L., Da Rin, M. (2002). "Venture capital in Europe and the financing of innovative companies”. Economic Policy 34, 229.269. 
Bottazzi, L., Da Rin, M. (2011). "Underpricing and voluntary information disclosure". Unpublished working paper.

Bottazzi, L., Da Rin, M., Hellmann, T. (2008). "Who are the active investors? Evidence from venture capital". Journal of Financial Economics 89, 488-512.

Bottazzi, L., Da Rin, M., Hellmann, T. (2009). "What is the role of legal systems in financial intermediation? Theory and evidence". Journal of Financial Intermediation 18, 559-598.

Bottazzi, L., Da Rin, M., Hellmann, T. (2011). “The importance of trust for investment: evidence from venture capital". Unpublished working paper.

Bozkaya, A., Kerr, W. (2011). "Labor regulations and European private equity“. Unpublished working paper.

Bradley, D., Kim, I., Krigman, L. (2011). "Currying favor with top venture capital firms: the role of IPO underpricing and all-star coverage". Unpublished working paper.

Brander, J., De Bettignies, J. (2009). "Venture capital investment: the role of predator-prey synamics with learning by doing". Economics of Innovation and New Technology 18, 1-19.

Brander, J., Amit, R., Antweiler, W. (2002). "Venture capital syndication: improved venture selection versus the value-added hypothesis". Journal of Economics and Management Strategy $11,423-452$.

Brander, J., Du, Q., Hellmann, T. (2010a). "Governments as venture capitalists: striking the right balance". In: Globalization of Alternative Investments, Volume 3: The Global Economic Impact of Private Equity Report 2010. World Economic Forum. 
Brander, J., Du, Q., Hellmann, T. (2011). “The effects of government-sponsored venture capital: international evidence“. Unpublished working paper.

Brander, J., Egan, E., Hellmann, T. (2010b). “Government sponsored versus private venture capital: Canadian evidence”. Unpublished working paper.

Brav, A., Gompers, P. (1997). "Myth or reality? The long-run underperformance of initial public offerings: evidence from venture- and non venture-capital-backed companies". Journal of Finance 52, 1791-1821.

Brav, A., Gompers, P. (2003). "The role of lockups in Initial Public Offerings”. Review of Financial Studies 16, 1-29.

Broughman, B. (2008). "Independent directors and board control in venture finance”. American Law and Economics Association Papers 41, 1-24.

Broughman, B, Fried J. (2010). "Renegotiation of cash flow rights in the sale of VC-backed firms". Journal of Financial Economics 95, 384-99.

Broughman, B., Fried, J. (2011). "VC inside rounds as rescue financing: theory and evidence". Unpublished working paper.

Bubna, A., Das, S., Prabhala, N. (2011). "Venture capital communities". Unpublished working paper.

Casamatta, C. (2003). "Financing and advising: optimal financial contracts with venture capitalists”. Journal of Finance 58, 2059-86. 
Casamatta, C., Haritchabalet, C. (2007). "Experience, screening and syndication in venture capital investments”. Journal of Financial Intermediation 16, 368-398.

Casamatta, C., Haritchabalet, C. (2011). "Dealing with venture capitalists: shopping around or exclusive negotiation". Unpublished working paper.

Cassiman, B., Ueda, M. (2006). “Optimal project rejection and new firm start-ups”. Management Science 52, 262-75.

Cestone, G. (2002). "Venture capital meets contract theory: risky claims or formal control?". CEPR Discussion Paper 3462.

Cestone, G., Lerner, J., White, L. (2006). “The design of syndicates in venture capital”. Unpublished working paper.

Chan, Y.-S., Siegel, D., Thakor, A. (1990). “Learning, corporate control and performance requirements in venture capital contracts”. International Economic Review 31, 365-381.

Chemmanur, T., Chen, Z. (2006). "Venture capitalists versus angels: the dynamics of private firm financing contracts". Unpublished working paper.

Chemmanur, T., Tian, X. (2010). "Peer monitoring, syndication, and the dynamics of venture capitalist interactions". Unpublished working paper.

Chemmanur, T., Hull, T., Krishnan, K. (2010). "Do local and international venture capitalists play well together? A study of international venture capital investments". Unpublished working paper. 
Chemmanur, T., Krishnan, K., Nandy, D. (2011a). "How does venture capital financing Improve efficiency in private firms? A look beneath the surface". Review of Financial Studies, forthcoming.

Chemmanur, T., Loutskina, E., Tian, X. (2011b). “Corporate venture capital, value creation, and innovation". Unpublished working paper.

Chen, J. (2009). "Selection and serial entrepreneurs". Unpublished working paper.

Chevalier, J., Ellison, G. (1997). "Risk taking by mutual funds as a response to incentives”. Journal of Political Economy 105, 1167-1200.

Chung, J.-W., Sensoy, B., Stern, L., Weisbach, M. (2010). "Pay for performance from future fund flows: the case of private equity". Unpublished working paper.

Cochrane, J. (2005). "The risk and return of venture capital”. Journal of Financial Economics 75, $3-52$.

Cockburn, I., MacGarvie, M. (2009). "Patents, thickets and the financing of early-stage firms: evidence from the software industry”. Journal of Economics and Management Strategy 18, 729773.

Colombo, M., Grilli, L., Piva, E. (2006). "In search of complementary assets: the determinants of alliance formation of high-tech start-ups". Research Policy 35, 1166-1199.

Cornelli, F., Yosha, O. (2003). "Stage financing and the role of convertible securities". Review of Economic Studies 70, 1-32. 
Cowling, M., Murray, G., Liu, W. (2010). “An independent econometric analysis of the "Innovation Investment Fund" programme (IIF) of the Australian commonwealth government: findings and implications". Department of Innovation, Industry, Science and Research, Commonwealth of Australia, Canberra.

Cumming, D. (2008). “Contracts and exits in venture capital finance". Review of Financial Studies 21, 1947-1982.

Cumming, D., MacIntosh, J. (2006). “Crowding out private equity: Canadian evidence”. Journal of Business Venturing 21, 569-609.

Cumming, D., Walz U. (2010). "Private equity returns and disclosure around the world". Journal of International Business Studies 41, 727-754.

Cumming, D., Fleming, G., Schwienbacher, A., (2005a). "Liquidity risk and venture capital finance”. Financial Management 34, 77-105.

Cumming, D., Fleming, G., Suchard J. (2005b). "Venture capitalist value-added activities, fundraising and drawdowns”. Journal of Banking and Finance 29, 295-331.

Cumming, D., Fleming, G., Schwienbacher, A., (2006). "Legality and venture capital exits". Journal of Corporate Finance 12, 214-45.

Cumming, D., Fleming, G., Schwienbacher, A., (2009). "Style drift in private equity”. Journal of Business Finance and Accounting 36, 645-78.

da Gbadji, L., Gailly, B., Schwienbacher, A. (2011). "International analysis of venture capital programs of large corporations and financial institutions". Unpublished working paper. 
Da Rin, M., Phalippou, L. (2011). "Cash rule in private equity”. Unpublished working paper.

Da Rin, M., Nicodano, G., Sembenelli, A. (2006). "Public policy and the creation of active venture capital markets". Journal of Public Economics 90, 1699-1723.

Dai, N., Jo, H., Kassicieh, S. (2009). "Venture capital ownership type, investment criteria and venture performance". Unpublished working paper.

Das, S., Jo, H., Kim, Y. (2011). "Polishing diamonds in the rough: the sources of syndicated venture performance". Journal of Financial Intermediation 20, 199-230.

Davila, A., Foster, G., Gupta, M. (2003). "Venture capital financing and the growth of start-up firms". Journal of Business Venturing 18, 689-708.

Davis, S., Haltiwanger, J., Jarmin, R., Lerner, J., Miranda, J. (2011). "Private equity and employment". Unpublished working paper.

de Bettignies, J.-E. (2008). "Financing the entrepreneurial venture". Management Science 54, $151-166$.

de Bettignies, J.-E., Brander, J. (2007). "Financing entrepreneurship: bank finance versus venture capital”. Journal of Business Venturing 22, 808-832.

de Bettignies, J.-E., Chemla, G. (2008). “Corporate venturing, allocation of talent, and competition for star managers". Management Science 54, 505-521.

Dessein, W. (2005). "Information and control in ventures and alliances". Journal of Finance 60, 2513-2549. 
Dessí, R. (2005). “Start-up finance, monitoring and collusion”. RAND Journal of Economics 36, $255-274$.

Dimov, D., Shepherd, D. (2005). "Human capital theory and venture capital firms: exploring "home runs" and "strike outs"“. Journal of Business Venturing 20, 1-21.

Driessen, J., Lin, T., Phalippou, L. (2011). “A new method to estimate risk and return of nontraded assets from cash flows: the case of private equity funds". Journal of Financial and Quantitative Analysis, forthcoming.

Du, Q. (2011). "Birds of a feather or celebrating differences? The formation and impact of venture capital syndication”. Unpublished working paper.

Duffner, S., Schmid, M., Zimmermann, H. (2009). "Trust and success in venture capital financing — an empirical analysis with German survey data”. Kyklos 62, 15-43.

Dushnitsky, G., Lenox, M. (2005). "When do firms undertake R\&D by investing in new ventures?" Strategic Management Journal 26, 947 -965.

Dushnitsky, G., Shapira, Z. (2010). "Entrepreneurial finance meets organizational reality: comparing investment practices by corporate and independent venture capitalists". Strategic Management Journal 31, 990-1017.

Dyck, A., Pomorski, L. (2011). "Is bigger better? Size and performance in pension plan management”. Unpublished working paper.

Eckhardt, J., Shane, S., Delmar, F. (2006). "Multistage selection and the financing of new ventures". Management Science 52, 220-232. 
Ellul, A., Pagano, M. (2006). "IPO underpricing and after-market liquidity". Review of Financial Studies 19, 381- 421.

Engel, D., Keilbach, M. (2007). "Firm level implications of early stage venture capital investments: an empirical investigation". Journal of Empirical Finance 14, 150-167.

Ewens, M. (2010). “Tail events in venture capital returns”. Unpublished working paper.

Fallick, B., Fleischman, C., Rebitzer, J. (2006). "Job-hopping in Silicon Valley: some evidence concerning the microfoundations of a high-technology cluster". Review of Economics and Statistics $88,472-481$.

Fitza, M., Matusik, S., Mosakowski, E. (2009). "Do VCs matter? The importance of owners on performance variance in start-up firms". Strategic Management Journal 30, 387-404.

Fluck, Z., Garrison, K., Myers, S. (2005). "Venture capital contracting and syndication: an experiment in computational corporate finance". Unpublished working paper.

Franco, A., Filson, D. (2006). "Spinouts: knowledge diffusion through employee mobility". RAND Journal of Economics 37, 841-860.

Franco, A., Mitchell, M. (2008). "Covenants not to compete, labor mobility, and industry dynamics". Journal of Economics and Management Strategy 17, 581-606.

Fulghieri, P., Sevilir, M. (2009a). "Organization and financing of innovation, and the choice between corporate and independent venture capital”. Journal of Financial and Quantitative Analysis 44, 1291-1321. 
Fulghieri, P., Sevilir, M. (2009b). "Size and focus of a venture capitalist's portfolio". Review of Financial Studies 22, 4643-4680.

Gans, J., Stern, S. (2000). "Incumbency and R\&D incentives: licensing the gale of creative destruction”. Journal of Economics and Management Strategy 9, 485-511.

Gans, J., Stern, S. (2003). "When does funding research by smaller firms bear fruit? Evidence from the SBIR program". Economics of Innovation and New Technology 16, 361-384.

Gans, J., Hsu, D., Stern, S. (2002). "When does start-up innovation spur the gale of creative destruction?" RAND Journal of Economics 33, 571-586.

Garcia-Appendini, E., Ippolito, F., Caselli, S. (2011). "Contracts and returns in private equity investments". Unpublished working paper.

Gebhardt, G., Schmidt, K. (2006). "Conditional allocation of control rights in venture capital firms". CEPR Discussion Paper 5758.

Gilson, R. (1999). “The legal infrastructure of high technology industrial districts: Silicon Valley, Route 128, and covenants not to compete”. York University Law Review 74, 575-629.

Gilson, R., Schizer, D. (2003).“Understanding venture capital structure: a tax explanation for convertible preferred stock". Harvard Law Review 116, 874-916.

Goldfarb, B., Hoberg, G., Kirsch, D., Triantis, A. (2009). "Does angel participation matter? An analysis of early venture financing”. Unpublished working paper.

Gompers, P. (1994). "The rise and fall of venture capital". Business and Economic History 23, 1 26. 
Gompers, P. (1995). "Optimal investment, monitoring, and the staging of venture capital". Journal of Finance 50, 1461-1489.

Gompers, P. (1996). "Grandstanding in the venture capital industry”. Journal of Financial Economics 42, 133-156.

Gompers, P. (1999). “Ownership and control in entrepreneurial firms: an examination of convertible securities in venture capital investment". Unpublished working paper.

Gompers, P. (2007). "Venture Capital". In Eckbo, E. (Ed.), Handbook of Corporate Finance, vol.1. North- Holland, Amsterdam.

Gompers, P., Lerner, J. (1996). "The use of covenants: an empirical analysis of venture partnership agreements". Journal of Law and Economics 39, 463-498.

Gompers, P., Lerner, J. (1997). "Risk and reward in private equity investments: The challenge of performance assessment". Journal of Private Equity 1, 5-12.

Gompers, P., Lerner, J. (1998a). "Venture capital distributions: short-run and long-run reactions". Journal of Finance 53, 2161-2183.

Gompers, P., Lerner, J. (1998b). "What drives venture capital fundraising?" Brookings Papers on Economic Activity. Microeconomics, 149-192.

Gompers, P., Lerner J. (1999a). "Conflict of interest in the issuance of public securities: evidence from venture capital". Journal of Law and Economics 42, 1-28.

Gompers, P., Lerner J. (1999b). “An analysis of compensation in the U.S. venture capital partnership". Journal of Financial Economics 51, 3-44. 
Gompers, P., Lerner, J. (2000a). "The determinants of corporate venture capital success". In: Morck, R. (Ed.), Concentrated Corporate Ownership. University of Chicago Press, Chicago.

Gompers, P., Lerner, J. (2000b). "Money chasing deals? The impact of fund inflows on private equity valuation". Journal of Financial Economics 55, 281-325.

Gompers, P., Lerner, J. (2001). “The venture capital revolution”. Journal of Economic Perspectives 15, 145-168.

Gompers, P., Xuan, Y. (2009). "Bridge building in venture capital-backed acquisitions". Unpublished working paper.

Gompers, P., Kovner, A., Lerner, J. (2009). "Specialization and success: evidence from venture capital”. Journal of Economics and Management Strategy 18, 817-844.

Gompers, P., Lerner, J., Scharfstein, D. (2005). "Entrepreneurial spawning: public corporations and the genesis of new ventures, 1986 to 1999". Journal of Finance 60, 577-614.

Gompers, P., Kovner, A., Lerner, J., Scharfstein, D. (2008). “Venture capital investment cycles: the impact of public markets". Journal of Financial Economics 87, 1-23.

Gompers, P., Lerner, J., Scharfstein, D., Kovner, A. (2010). "Performance persistence in entrepreneurship". Journal of Financial Economics 96, 18-32.

Gorman, M., Sahlman, W. (1989). "What do venture capitalists do?” Journal of Business Venturing 4, 231-248.

Hall, J., Hofer. C. (1993). "Venture capitalists' decision criteria in new venture evaluation". Journal of Business Venturing 8, 25-42. 
Hall, R., Woodward, S. (2010). "The burden of the non-diversifiable risk of entrepreneurship". American Economic Review 100, 1163-1194.

Hand, J. (2008). "Give everyone a prize? Employee stock options in private venture-backed firms". Journal of Business Venturing 23, 385-404.

Hazarika, S., Nahata, R., Tandon, K. (2009). "Success in global venture capital investing: do institutional and cultural differences matter?" Unpublished working paper.

Hellmann, T. (1998). "The allocation of control rights in venture capital contracts". RAND Journal of Economics 29, 57-76.

Hellmann, T. (2002). "A theory of strategic venture investing”. Journal of Financial Economics 64, 285-314.

Hellmann, T. (2003). "Going public and the option value of convertible securities in venture capital". Unpublished working paper.

Hellmann, T. (2006). "IPOs, acquisitions, and the use of convertible securities in venture capital”. Journal of Financial Economics 81, 649-679.

Hellmann, T. (2007). "Entrepreneurs and the process of obtaining resources". Journal of Economics and Management Strategy 16, 81-109.

Hellmann, T., Perotti, E. (2011). "The circulation of ideas in firms and markets". Management Science, forthcoming.

Hellmann, T., Puri, M. (2000). “The Interaction between product market and financing strategy: the role of venture capital". Review of Financial Studies 13, 959-984. 
Hellmann, T., Puri, M. (2002). "Venture capital and the professionalization of start-up firms: empirical evidence". Journal of Finance 57, 169-197.

Hellmann, T., Lindsey, L., Puri, M. (2008). "Building relationships early: banks in venture capital". Review of Financial Studies 21, 513-541.

Hirukawa, M., Ueda, M. (2008a). "Venture capital and industrial innovation". CEPR Discussion Paper 7089.

Hirukawa, M., Ueda, M. (2008b). "Venture capital and innovation: which is first?" CEPR Discussion Paper 7090.

Hoberg, G., and Seyhun, H. (2010). "Do underwriters collaborate with venture capitalists in IPOs? Implications and evidence". Unpublished working paper.

Hochberg, Y. (2011). "Venture capital and corporate governance in the newly public firm". Review of Finance, forthcoming.

Hochberg, Y., Rauh, J. (2011). “Local overweighting and underperformance: evidence from limited partner private equity investments". Unpublished working paper.

Hochberg, Y., Westerfield, M. (2010). “The size and specialization of direct investment portfolios". Unpublished working paper.

Hochberg, Y., Ljungqvist, A., Lu, Y. (2007). “Whom you know matters: venture capital networks and investment performance”. Journal of Finance 62, 251-301.

Hochberg, Y., Ljungqvist, A., Lu, Y. (2010a). "Networking as a barrier to entry and the competitive supply of venture capital". Journal of Finance 65, 829-859. 
Hochberg, Y., Ljungqvist, A., Vissing-Jorgensen, A. (2010b). "Informational hold-up and performance persistence in venture capital”. Unpublished working paper.

Hochberg, Y., Lindsey, L., Westerfield, M. (2011a). "Inter-firm economic ties: evidence from venture capital”. Unpublished working paper.

Hochberg, Y., Mazzeo, M., McDevitt, R. (2011b). "Market structure and competition in the venture capital industry". Unpublished working paper.

Hsu, D. (2004). "What do entrepreneurs pay for venture capital affiliation?” Journal of Finance $59,1805-1844$.

Hsu, D. (2006). "Venture capitalists and cooperative start-up commercialization strategy". Management Science 52, 204-219.

Hsu, D. (2007). “Experienced entrepreneurial founders, organizational capital, and venture capital funding“. Research Policy 36, 722-741.

Hsu, D., Kenney, M. (2005). “Organizing venture capital: the rise and demise of American Research \& Development Corporation, 1946-1973”. Industrial and Corporate Change 14, 579616.

Hsu, D., Ziedonis, R. (2011). "Strategic factor markets and the financing of technology startups: when do patents matter more as signaling devices?" Unpublished working paper.

Hyde, A. (1998). "Silicon valley's high-velocity labor market". Journal of Applied Corporate Finance 11, 28-37. 
Inderst, R., Müller, H. (2004). "The effect of capital market characteristics on the value of startup firms". Journal of Financial Economics 72, 319-356.

Inderst, R., Müller, H. (2009). "Early-stage financing and firm growth in new industries". Journal of Financial Economics 93, 276-91.

Inderst, R., Müller, H., Muennich, F. (2007). "Financing a portfolio of projects". Review of Financial Studies 20, 1289-1325.

Ivanov, V., Masulis, R. (2011). "Corporate venture capital and corporate governance in newly public firms". Unpublished working paper.

Ivanov, V., Xie, F. (2010). “Do corporate venture capitalists add value to start-up firms? Evidence from IPOs and Acquisitions of VC-backed companies". Financial Management 35, $129-152$.

Jegadeesh, N., Kräussl, R., Pollet, J. (2010). "Risk and expected returns of private equity investments: evidence based on market prices". NBER Working Paper 15335.

Jeng, L., Wells, P. (2000). “The determinants of venture capital funding: evidence across countries". Journal of Corporate Finance 6, 241-289.

Johnson, W., Sohl, J. (2011). "Initial public offerings and pre-IPO shareholders: angels versus venture capitalists". Unpublished working paper.

Jones, C., Rhodes-Kropf, M. (2004). "The price of diversifiable risk in venture capital and private equity". Unpublished working paper. 
Kandel, E., Leshchinskii, D., Yuklea, H. (2011). "VC funds: aging brings myopia". Journal of Financial and Quantitative Analysis 46, 431-457.

Kang, D., Nanda, V. (2011). “Complements or substitutes? Technological and financial returns created by corporate venture capital investments". Unpublished working paper.

Kanniainen, V., Keuschnigg, C. (2004). "Start-up investment with scarce venture capital support". Journal of Banking and Finance 28, 1935-1959.

Kaplan, S., Lerner, J. (2010). "It ain't broke: the past, present, and future of venture capital". Journal of Applied Corporate Finance 22, 36-47.

Kaplan, S., Schoar, A. (2005). "Private equity performance: returns, persistence, and capital flows". Journal of Finance 60, 1791-1823.

Kaplan, S., Strömberg, P. (2003). "Financial contracting theory meets the real world: an empirical analysis of venture capital contracts”. Review of Economic Studies 70, 281-315.

Kaplan, S., Strömberg, P. (2004). "Characteristics, contracts, and actions: evidence from venture capitalist analyses." Journal of Finance 59, 2177-2210.

Kaplan, S., Strömberg, P. (2009). "Leveraged buyouts and private equity“. Journal of Economic Perspectives 23, 121-146.

Kaplan, S., Klebanov, M., Sørensen, M., (2010) "Which CEO characteristics and abilities matter?" Unpublished working paper.

Kaplan, S., Martel, F., Strömberg, P. (2007). "How do legal differences and experience affect financial contracts?” Journal of Financial Intermediation 16, 273-311. 
Kaplan, S., Sensoy, B., Strömberg, P. (2002). "How well do venture capital databases reflect actual investments?" Unpublished working paper.

Kaplan, S., Sensoy, B., Strömberg, P. (2009). "Should investors bet on the jockey or the horse? Evidence from the evolution of firms from early business plans to public companies". Journal of Finance 64, 75-115.

Kerr, W., Nanda, R. (2011). "Financing constraints and entrepreneurship". In: Audretsch, D., Falck, O., Heblich, S. (Eds.) Handbook on Research on Innovation and Entrepreneurship. Edward Elgar, Cheltenham.

Kerr, W., Lerner, J., Schoar, A. (2011). "The consequences of entrepreneurial finance: a regression discontinuity analysis". Review of Financial Studies, forthcoming.

Keuschnigg, C., Nielsen, S. (2004). "Start-ups, venture capitalists, and the capital gains tax". Journal of Public Economics 88, 1011-1042.

Kirilenko, A. (2001). "Valuation and control in venture finance". Journal of Finance 56, 565587.

Klepper, S., Sleeper, S. (2005). "Entry by spinoffs”. Management Science 51, 1291-1306.

Klepper, S., Thompson, P. (2010). "Disagreements and intra-industry spinoffs". International Journal of Industrial Organization 28, 526-538.

Korteweg, A., Sørensen, M. (2010). "Risk and return characteristics of venture capital-backed entrepreneurial companies". Review of Financial Studies 23, 3738-3772. 
Kortum, S., Lerner, J. (2000). "Assessing the contribution of venture capital to innovation". Rand Journal of Economics 31, 674-692.

Krishnan, C., Masulis, R., Ivanov, V., Singh, A. (2011). "Venture capital reputation, post-IPO performance and corporate governance". Journal of Financial and Quantitative Analysis, forthcoming.

Krohmer, P., Lauterbach, R., Calanog, V. (2009). “The bright and dark side of staging: investment performance and the varying motivations of private equity". Journal of Banking and Finance 33, 1597-1609.

Kroszner, R., Rajan, R. (1994). "Is the Glass-Steagall act justified? A study of the U.S. experience with universal banking before 1933”. American Economic Review 84, 810-832.

Landier, A. (2003). "Start-up financing: from banks to venture capital". Unpublished working paper.

Landier, A. (2006). "Entrepreneurship and the stigma of failure". Unpublished working paper.

Lee, G., Masulis, R. (2011). “Do underwriters or venture capitalists restrain earnings management by IPO issuers?" Journal of Corporate Finance, forthcoming.

Lee, P., Wahal, S. (2004). “Grandstanding, certification and the underpricing of venture capital backed IPOs”. Journal of Financial Economics 73, 375-407.

Leleux, B., Surlemont, B. (2003). "Public versus private venture capital: seeding or crowding out? A pan-European analysis". Journal of Business Venturing 18, 81-104. 
Lerner, J. (1994a). "Venture capitalists and the decision to go public". Journal of Financial Economics 35, 293-316.

Lerner, J. (1994b). “The syndication of venture capital investments”. Financial Management 23, $16-27$.

Lerner, J. (1995). "Venture capitalists and the oversight of private firms". Journal of Finance 50, 301-318.

Lerner, J. (1998). “Angel financing and public policy: an overview.” Journal of Banking and Finance 22, 773-83.

Lerner, J. (1999). “The government as venture capitalist: the long-run impact of the SBIR program”. Journal of Business 72, 285-318.

Lerner, J., Schoar, A. (2004). "The illiquidity puzzle: theory and evidence from private equity". Journal of Financial Economics 72, 3-40.

Lerner, J., Schoar, A. (2005). "Does legal enforcement affect financial transactions? The contractual channel in private equity". Quarterly Journal of Economics 120, 223-246.

Lerner, J., (2008). Boulevard Of Broken Dreams: Why Public Efforts To Boost Entrepreneurship And Venture Capital Have Failed. Princeton University Press, Princeton.

Lerner, J., Schoar, A., Wongsunwai, W. (2007). "Smart institutions, foolish choices? The limited partner performance puzzle”. Journal of Finance 62, 731-764.

Lerner, J., Shane, H., Tsai, A. (2003). "Do equity financing cycles matter? Evidence from biotechnology alliances”. Journal of Financial Economics 67, 411-446. 
Li, K., Prabhala, N. (2007). "Self-selection models in corporate finance”. In: Gecko, E. (Ed.), Handbook of Corporate Finance: Empirical Corporate Finance, Vol. I. North Holland, Amsterdam.

Lin, T., Smith, R. (1998). "Insider reputation and selling decisions: the unwinding of venture capital investments during equity IPOs". Journal of Corporate Finance 4, 241-263.

Lindsey, L. (2008). "Blurring firm boundaries: the role of venture capital in strategic alliance". Journal of Finance 63, 1137-1168.

Litvak, K. (2009a). "Venture capital partnership agreements: understanding compensation arrangements". University of Chicago Law Review 76, 161-218.

Litvak, K. (2009b). “Governing by exit: default penalties and walkway options in venture capital partnership agreements". Willamette Law Review 40, 771-812.

Liu, X., Ritter, J.R. (2011). “Local underwriter oligopolies and IPO underpricing”. Journal of Financial Economics, forthcoming.

Ljungqvist, A., Richardson, M. (2003). "The Cash Flow, return and risk characteristics of private equity”. Unpublished working paper.

Loughran, T., Ritter, J. (1995). “The new issues puzzle”. Journal of Finance 50, 23-51.

Maats, F., Metrick, A., Yasuda, A., Hinkes, B., Vershovski, S. (2011). “On the consistency and reliability of venture capital databases". Unpublished working paper.

MacMillan, I., Siegel, R. Narasimha. P. (1985). "Criteria used by venture capitalists to evaluate new venture proposals". Journal of Business Venturing, 1, 119-128. 
Mann, R., Sager, T. (2007). "Patents, venture capital, and software start-ups”. Research Policy 36, 193-208.

Marquez, R., Nanda, V., Yavuz, D. (2010). "Private equity fund returns: do managers actually leave money on the table?". Unpublished working paper.

Marx, L. (1998). "Efficient venture capital financing combining debt and equity". Review of Economic Design 3, 371-387.

Marx, L., Strumsky, D., Fleming, L. (2009). "Mobility, skills, and the Michigan non-compete experiment”. Management Science 55, 875-889.

Masulis, R., Nahata, R. (2009). "Financial contracting with strategic investors: evidence from corporate venture capital backed IPOs". Journal of Financial Intermediation 18, 599-631.

Masulis, R., Nahata, R. (2011). "Venture capital conflicts of interest: evidence from acquisitions of venture backed firms”. Journal of Financial and Quantitative Analysis 46, 395-430.

Mathews, R. (2006). "Strategic alliances, equity stakes, and entry deterrence”. Journal of Financial Economics 80, 35-79.

Maula, M., Murray, G. (2001). “Corporate venture capital and the creation of US public companies". In: Hitt, A., Amit, R., Lucier, C., Nixon, D. (Eds.), Creating Value: Winners in the New Business Environment. Blackwell, New York.

Maula, M., Murray G. (2003). "Finnish industry investment ltd.: an international evaluation, report to Finnish Ministry of Trade and Industry”. Minister of Trade and Industry, Helsinki. 
Mayer, C, Schoors, K., Yafeh, Y. (2005). "Sources of funds and investment activities of venture capital funds: evidence from Germany, Israel, Japan and the United Kingdom”. Journal of Corporate Finance 11, 586-608.

Megginson, W., Weiss, K. (1991). "Venture capitalist certification in initial public offerings". Journal of Finance 46, 879-903.

Metrick, A., Yasuda, A. (2010). “The economics of private equity funds”. Review of Economic Studies 23, 2303-2341.

Metrick, A., Yasuda, A. (2011). "Venture capital and other private equity: a survey". European Financial Management 17, 619-654.

Michelacci, C., Suarez, J. (2004). "Business creation and the stock Market”. Review of Economic Studies 71, 459-481.

Mollica, M., Zingales, L. (2007). "The impact of venture capital on innovation and the creation of new businesses". Unpublished working paper.

Moskowitz,T., Vissing-Jørgensen, A. (2002). "The returns to entrepreneurial investment: a private equity premium puzzle?“'American Economic Review 92, 745-778.

Nahata, R. (2008). "Venture capital reputation and investment performance". Journal of Financial Economics 90, 127-151.

Nanda, R., Rhodes-Kropf, M. (2010). “Financing risk and bubbles of innovation”. Unpublished working paper. 
Neher, D. (1999). "Staged financing: an agency perspective". Review of Economic Studies 66, 255-274.

Neus, W., Walz, U. (2005). "Exit timing of venture capitalists in the course of an initial public offering”. Journal of Financial Intermediation 14, 253-277.

Norbäck, P., Persson, L. (2009). "The organization of the innovation industry: entrepreneurs, venture capitalists, and oligopolists". Journal of the European Economic Association 7, 1261-90.

Ozmel, U., Robinson, D., Stuart, T. (2007). "Strategic alliances, venture capital, and exit decisions in early stage high-tech firms". Unpublished working paper.

Paik, Y. (2010). "Serial entrepreneurs and venture performance: evidence from U.S. venturecapital-financed semiconductor firms”. Unpublished working paper.

Park, H., Steensma, K. (2011). "When does corporate venture capital add value for new ventures?" Strategic Management Journal, forthcoming.

Phalippou, L. (2008). "The hazards of using IRR to measure performance: the case of private equity”. Journal of Performance Measurement 4, 55-67.

Phalippou, L. (2010). "Venture capital funds: performance persistence and flow-performance relation”. Journal of Banking and Finance, Forthcoming.

Phalippou, L. (2011). "Why is the evidence on private equity performance so confusing?" Unpublished working paper.

Phalippou, L., Gottschalg, O. (2009). "The performance of private equity funds". Review of Financial Studies 22, 1747-1776. 
Plehn-Dujowich, J., Serfes, K., Thiele, V. (2011). “Entry and the efficiency of venture capital markets with endogenous matching". Unpublished working paper.

Popov, A., Roosenboom, P. (2008). "Venture capital and industrial innovation: evidence from Europe". Unpublished working paper.

Popov, A., Roosenboom, P. (2009). “Does private equity investment spur innovation? Evidence from Europe". European Unpublished working paper.

Poterba, J. (1989a). "Venture capital and capital gains taxation". Tax Policy and the Economy 3, 47.

Poterba, J., (1989b). “Capital gains tax policy toward entrepreneurship”. National Tax Journal $42,375-390$.

Prowse, S. (1998). "Angel investors and the market for angel investments". Journal of Banking and Finance 22, 785-92.

Puri, M. (1994). "The long-term default performance of bank underwritten security issues". Journal of Banking and Finance 18, 397-418.

Puri, M. (1996). "Commercial banks in investment banking: conflict of interest or certification role?" Journal of Financial Economics 40, 373-401.

Puri, M., Robinson, D. (2011a). “Optimism and economic choice”. Journal of Financial Economics 86, 71-99.

Puri, M., Robinson, D. (2011b) “The economic psychology of entrepreneurship and family business". Unpublished working paper. 
Puri, M., Zarutskie, R. (2011). "On the lifecycle dynamics of venture-capital- and non-venturecapital-financed firms". Journal of Finance, forthcoming.

Rajan, R., Zingales, L. (1998). "Financial dependence and growth". American Economic Review $88,59-86$.

Ray, K. (2010). "Staged investments in entrepreneurial financing". ”. Unpublished working paper.

Repullo, R., Suarez, J. (2004). "Venture capital finance: a security design approach". Review of Finance 8, 75-108.

Ritter, J. (2011). “Initial public offerings: tables updated through 2010”. Unpublished working paper.

Riyanto, Y., Schwienbacher, A. (2006). "The strategic use of corporate venture financing for securing demand". Journal of Banking and Finance 10, 2809-2833.

Robb, A., Robinson, D. (2010). "The capital structure decisions of new firms”. Unpublished working paper.

Robb, A., Reedy, E., Ballo, J., DesRoches, D., Potter, F., Zhao, Z. (2010). “An overview of the Kauffman firm survey: results from the 2004-2008 data”. Unpublished working paper.

Roberts, M., Whited, T. (2012). “Endogeneity in Empirical Corporate Finance”. In:

Constantinides, G., Harris, M., Stulz, R. (Eds), Volume of Handbook of the Economics of Finance, vol 2. North Holland, Amsterdam forthcoming. 
Robinson, D., Sensoy, B. (2011a). “Cyclicality, Performance Measurement, and Cash Flow Liquidity in Private Equity". Unpublished working paper.

Robinson, D., Sensoy, B. (2011b). "Manager compensation, ownership, and the cash flow performance of private equity funds". Unpublished working paper.

Robinson, D., Stuart, T. (2007). "Financial contracting in biotech strategic alliances". Journal of Law and Economics 50, 559-596.

Sahlman, W. (1990). "The structure and governance of venture-capital organizations". Journal of Financial Economics 27, 473-521.

Samila, S., Sorenson, O. (2010). "Venture capital as a catalyst to innovation". Research Policy, 39, 1348-1360.

Samila, S., Sorenson, O. (2011). "Venture capital, entrepreneurship, and economic growth". Review of Economics and Statistics 93, 338-349.

Sapienza, H. (1992). "When do venture capitalists add value?” Journal of Business Venturing 7, 9-27.

Sapienza, H., Gupta, A. (1994). "Impact of agency risks and task uncertainty on venture capitalist-CEO interaction”. Academy of Management Journal 37, 1618-1632.

Schertler, A, Tykvová T. (2010) “What lures cross-border venture capital inflows?” Unpublished working paper.

Schindele, I. (2006). "Advice and monitoring: venture financing with multiple tasks". Unpublished working paper. 
Schmidt, K. (2003). "Convertible securities and venture capital finance”. Journal of Finance 58, 1139-1166.

Schwienbacher, A. (2007). "A theoretical analysis of optimal financing strategies for different types of capital-constrained entrepreneurs". Journal of Business Venturing 22, 753-781.

Schwienbacher, A. (2008). "Innovation and venture capital exits". Economic Journal 118, 18881916.

Schwienbacher, A. (2009). "Financing commitments and investors incentives in entrepreneurial firms". Unpublished working paper.

Sevilir, M. (2010). "Human capital investment, new firm creation and venture capital". Journal of Financial Intermediation 19, 483-508.

Shane, S., Stuart, T. (2002). "Organizational endowments and the performance of university start-ups”. Management Science 48, 154-170.

Silviera, R., Wright, R. (2006). “The venture capital cycle”. Unpublished working paper.

Sørensen, M. (2007). "How smart is smart money? A two-sided matching model of venture capital". Journal of Finance 62, 2725-2762.

Sørensen, M. (2008). "Learning by investing: evidence from venture capital”. Unpublished working paper.

Sorenson, O., Stuart, T. (2001). "Syndication networks and the spatial distribution of venture capital investments". American Journal of Sociology 106, 1546-1588. 
Sorenson, O., Stuart, T. (2008). "Bringing the context back in: settings and the search for syndicate partners in venture capital investment networks". Administrative Science Quarterly 53, 266-294.

Stuart, T., Sorenson, O. (2003). "Liquidity events and the geographic distribution of entrepreneurial activity”. Administrative Science Quarterly 48, 175-201.

Sunesson, T. (2009). "Alma mater matters: the value of school ties in the venture capital industry”. Unpublished working paper.

Tian, X. (2011). "The causes and consequences of venture capital stage financing”. Journal of Financial Economics 101, 132-159.

Tian, X., T. Wang (2011) “Tolerance for failure and corporate innovation”. Review of Financial Studies, forthcoming.

Tian, X., Udell, G., Yu, X. (2011) “Disciplining delegated monitors: the consequences of failing to prevent fraud". Unpublished working paper.

Trester, J. (1998). "Venture capital contracting under asymmetric information”. Journal of Banking and Finance 22, 675-699.

Tykvová, T. (2007). "Who chooses whom? Syndication, skills, and reputation". Review of Financial Economics 16, 5-28.

Tykvová, T., Walz, U. (2005). “Are IPOs of different VCs different?” Unpublished working paper. 
Ueda, M. (2004). "Banks versus venture capital: project evaluation, screening, and expropriation”. Journal of Finance 59, 601-621.

Wasserman, N. (2003). "Founder-CEO succession and the paradox of entrepreneurial success". Organization Science 14, 149-172.

Wasserman, N. (2006). "Stewards, agents, and the founder discount: executive compensation in new ventures". Academy of Management Journal 49, 960-76.

Winton, A., Yerramilli, V. (2008). "Entrepreneurial finance: banks versus venture capital”. Journal of Financial Economics 88, 51-79.

Wongsunwai, W. (2011). "The effect of external monitoring on accruals-based and real earnings management: evidence from venture-backed initial public offerings”. Unpublished working paper.

Woodward, S. (2009). "Measuring risk for venture capital and private equity portfolios". Unpublished working paper.

Zarutskie, R. (2010). "The role of top management team human capital in venture capital markets: Evidence from first-time funds”. Journal of Business Venturing 25, 155-172. 